\title{
A Paleoenvironmental Interpretation of the Pukenui Limestone and Hautotara Formation, Southeastern Wairarapa, New Zealand
}

\author{
Lockie Joseph Hobbs
}

\begin{abstract}
A thesis submitted to Victoria University of Wellington in partial fulfilment of the requirement of the degree of Master of Science in Geology
\end{abstract}

School of Geography, Environment, and Earth Sciences

Victoria University of Wellington

2019 



\section{Frontispiece}

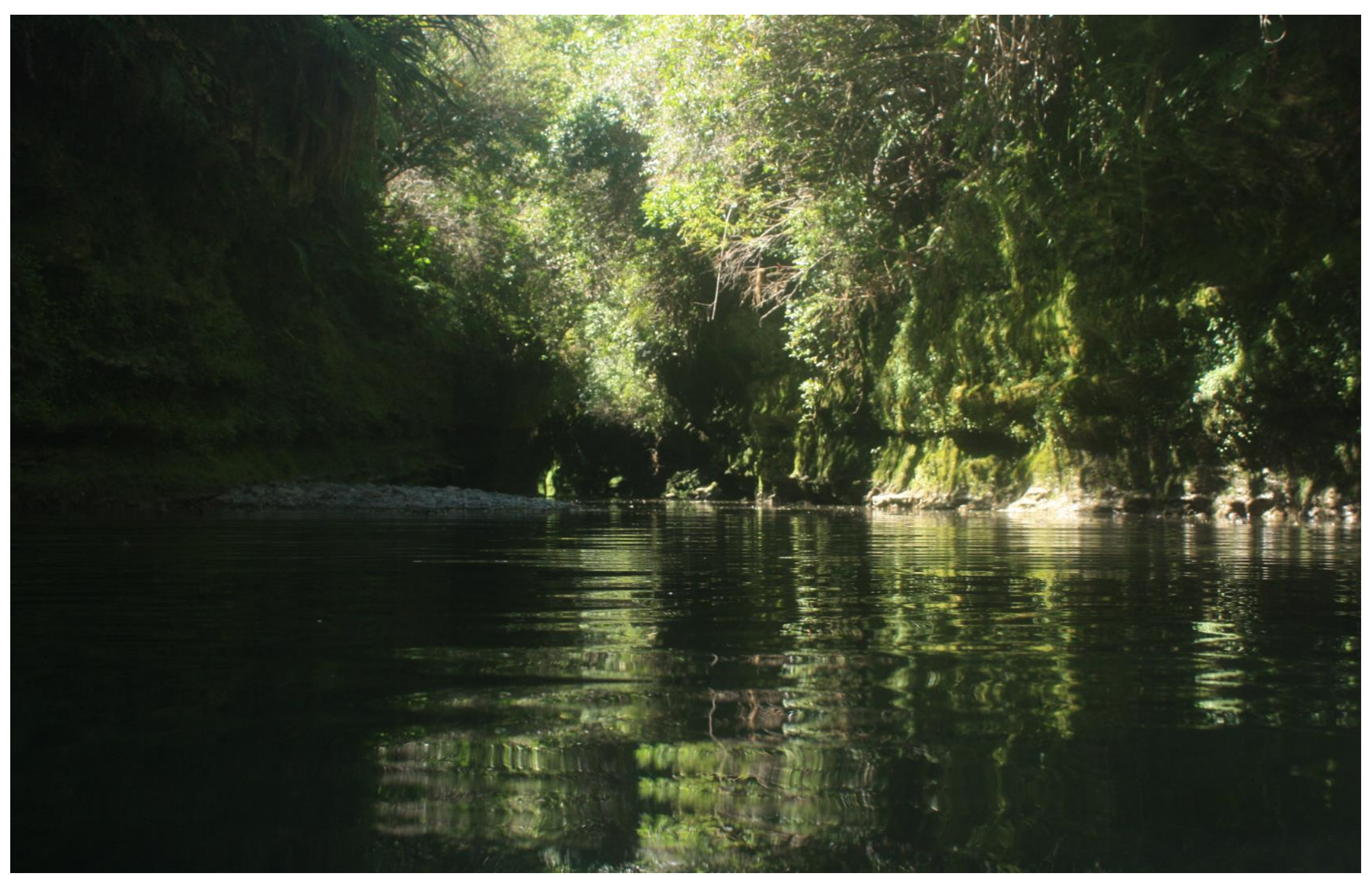

The Makara River bisecting the Pukenui Limestone near the type section at the southern end of the Nga-Waka-A-Kupe Range 


\section{Abstract}

Two sections from the northern part of the Nga-Waka-A-Kupe Range have been documented in detail. Both sections were expected to cut through sediments of Pleistocene age which at the southern end of the range have been attributed to the Greycliffs Formation, Pukenui Limestone, Hautotara and Te Muna Formations. The Longbush Road section only included the upper Pukenui Limestone to Hautotara Formation. The Hinakura Road section was as expected and included the entire Pukenui Limestone and Hautotara Formation. Previous works in the Popes Head area have recognised the same sequence there. However, only a few correlations can confidently be made between the two areas. This is largely due to the Pukenui Limestone at Popes Head exhibiting a markedly different set of facies to the section in the southern part of the range - its type section.

The facies analysis on the two sections here reveals that the depositional environment for the Pukenui Limestone in the Popes Head area is of a near-coastal environment close to the discharge of a large river, where the nearby type section is interpreted as representing deeper marine conditions. The differences in environments could be due to shallowing section or increased discharge from the river in the Popes Head area. More likely, however, it is a combination of these two factors that result in a shallow-water facies. 


\section{Acknowledgements}

I owe a great deal of thanks to Mike Hannah and Katie Collins, my supervisors who had more patience than most would need, but I did. Thank you for taking your time and helping me every step of the way. Mike, you managed to put up with my almost hourly visits to discuss even the smallest problems. Katie, despite being halfway around the world, you would shoot back emails faster than I could write them, and I am forever grateful for your macrofossil identification and critical thinking. Cliff Atkins, thank you for taking the time to help me with all things facies related, a crucial aspect of this work.

My gratitude must be extended to the local farmers whose properties I accessed. They readily gave me access to their land, took interest in my work, and offered assistance where possible. Special thanks go to Mike Cutfield and family for kindly providing accommodation when needed, and to Sam Welch for coordinating access to property in the area.

Numerous staff at Vic and GNS for helping with many aspects of my work. Dez Tessler for Health and Safety, organising field equipment and transport for me to use. Andrew Rae for help with GIS. Jane Chewings for lab assistance. Alan Beu for macrofossil identification. To Ben Hines for assistance in the field: I wouldn't have learnt nearly so much without you showing me the ropes and answering my endless pestering questions. To all other staff and students whom I've had the privilege of spending time with in the field, thank you for any and all assistance and ideas.

My friends in JB and the rest of the department: Ben Cathie, Max Sharpe, Jacob Leath, Becca Pretty, Nikita Turton, and others, you have been a constant source of entertainment, inspiration, support, and assistance.

To Libby, thank you for supporting me every step of the way and making sure I knew that I had what it takes, for looking after me at every one of my numerous and apparently unavoidable knockdowns, and for accompanying me on my adventures. Thank you for being by my side.

I certainly would not have made it through without the continued support of a numerous amount of family and friends. My parents, sister, and grandparents, who were there for me every step of the way. The Wellington Board and all other family friends, for offering meals, board, space to chill out when it got tough, I couldn't have done it without you. You were all on my mind constantly and have been more help than you could ever know. 


\section{Contents}

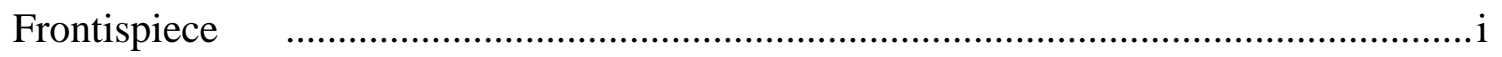

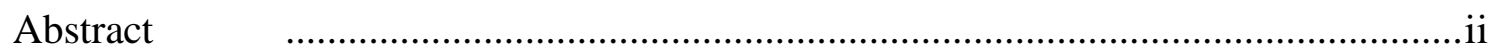

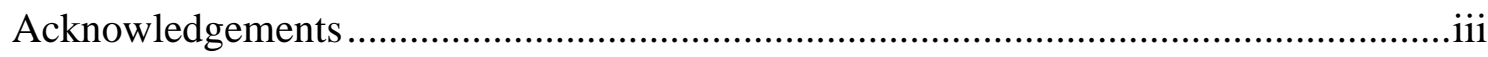

Contents

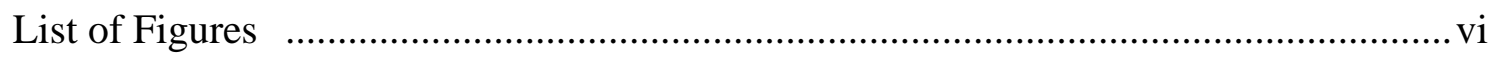

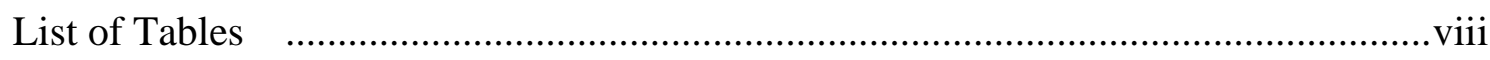

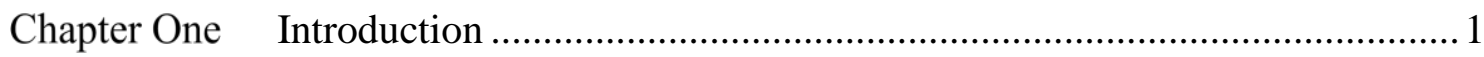

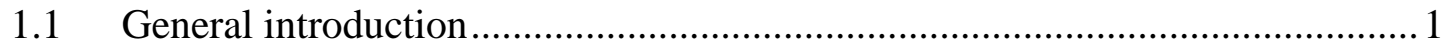

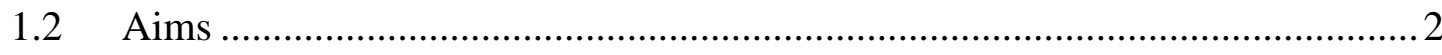

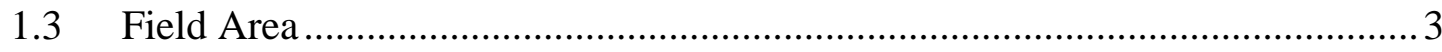

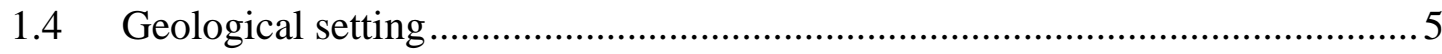

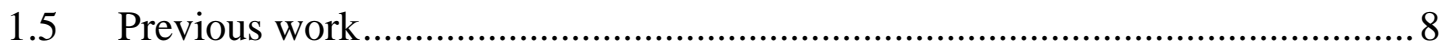

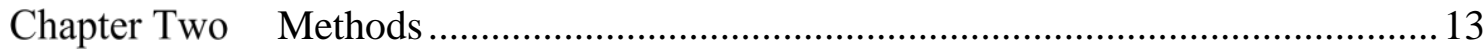

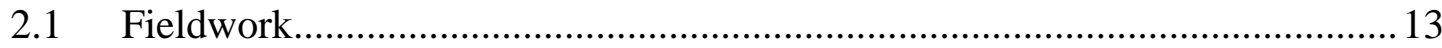

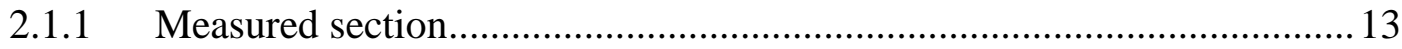

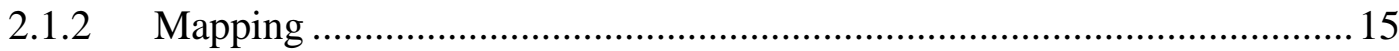

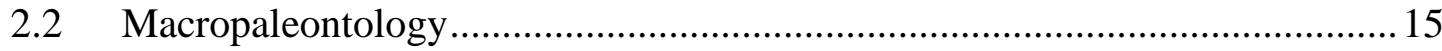

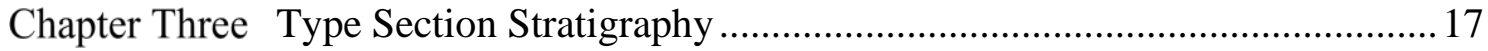

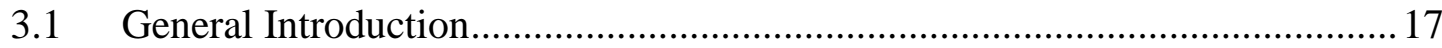

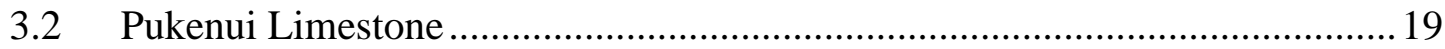

3.2.1 Type Section Location ..................................................................... 19

3.2.2 Generalised Pukenui Limestone Description .........................................20

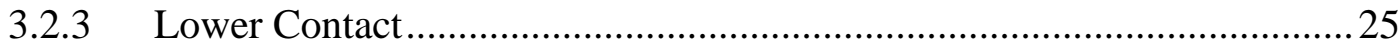

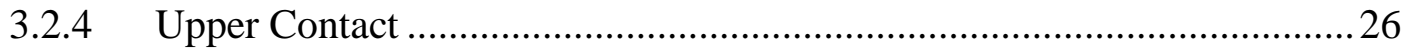

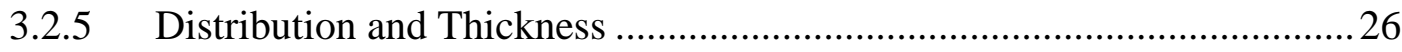

3.2.6 Paleontology, Age, and Environment of Deposition ..............................26

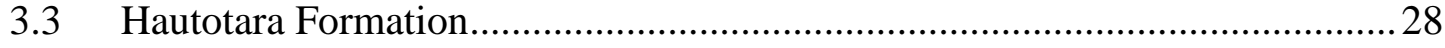

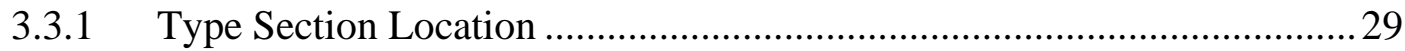

3.3.2 Generalised Hautotara Formation Description .......................................22

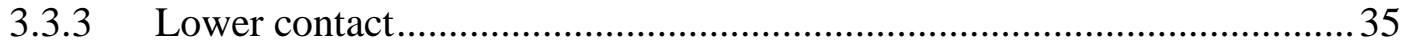

3.3.4 Top Contact and Te Muna Formation .................................................... 36

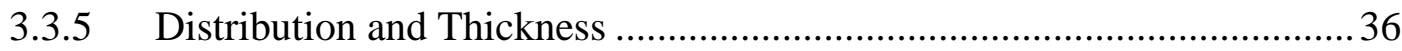

3.3.6 Paleontology, Age, and Environment of Deposition ................................ 36 


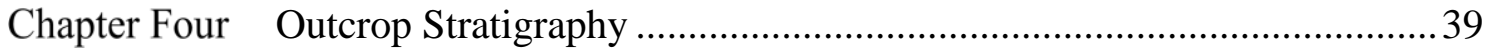

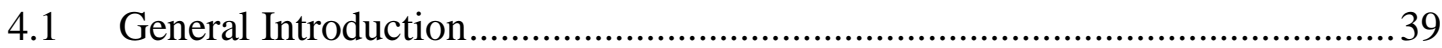

4.2 Stratigraphy of the Hinakura Road Measured Section ......................................39

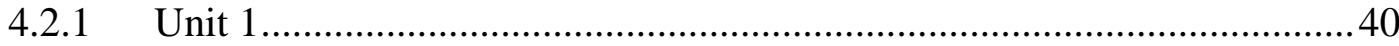

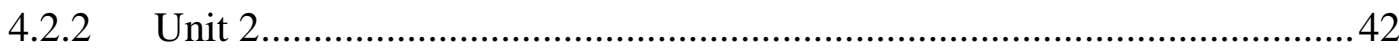

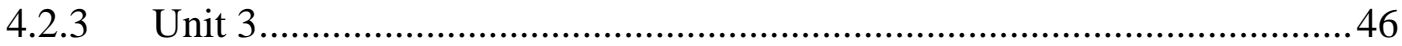

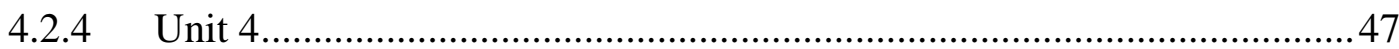

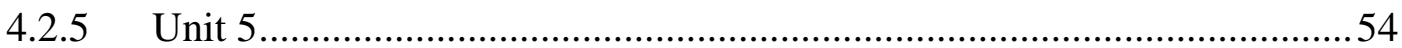

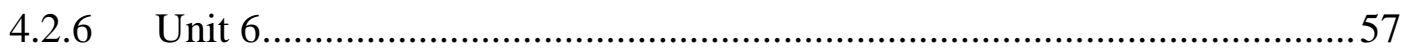

4.3 Stratigraphy of the Longbush Road Measured Section ...................................58

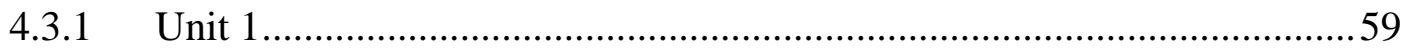

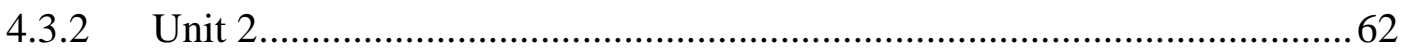

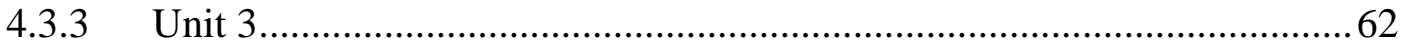

4.4 Correlation between measured sections ........................................................63

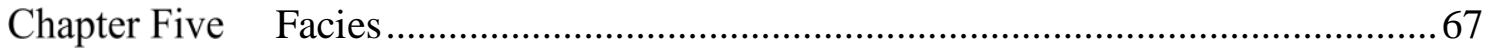

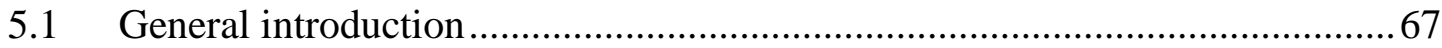

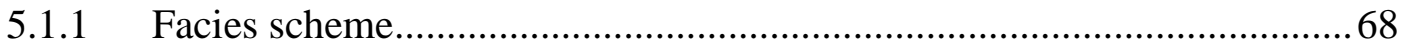

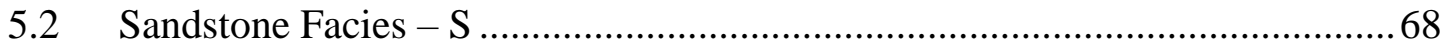

5.2.1 Subfacies 1: $\mathrm{S}_{\mathrm{N}}-$ Non-fossiliferous Sandstone .....................................6 68

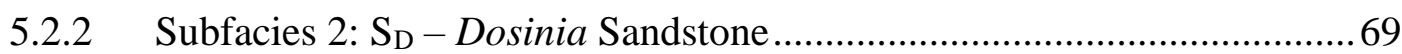

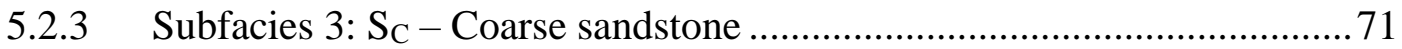

5.2.4 Subfacies 4: $\mathrm{S}_{\mathrm{S} / \mathrm{M}}$ - Alternating sandstone/mudstone............................... 72

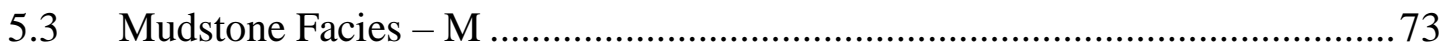

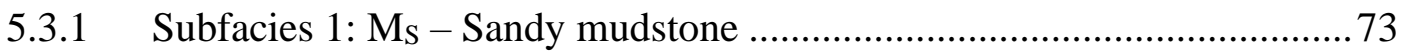

5.3.2 Subfacies 2: $\mathrm{M}_{\mathrm{F}}-$ Fossiliferous Mudstone .......................................... 74

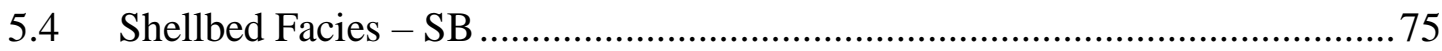

5.4.1 Subfacies 1: $\mathrm{SB}_{\mathrm{A}}$ : Austrovenus shellbed................................................. 75

5.4.2 Subfacies 2: $\mathrm{SB}_{\mathrm{T}}$ : Tawera subsulcata dominated shellbed .......................77

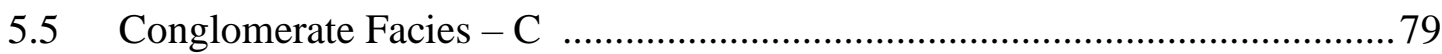

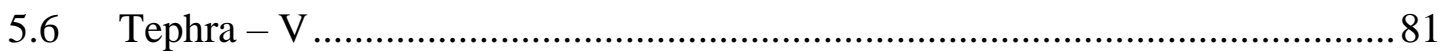

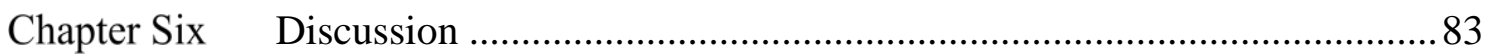

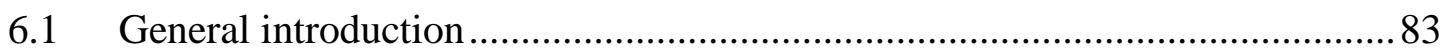

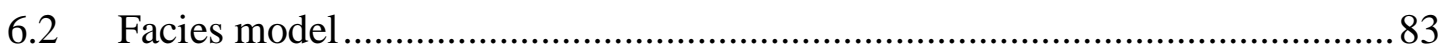

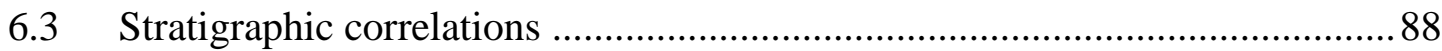

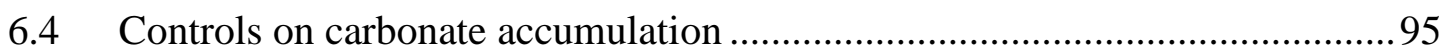




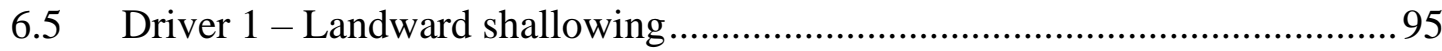

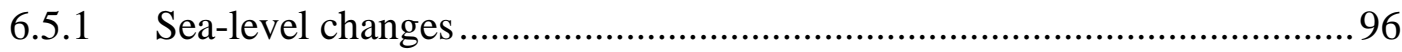

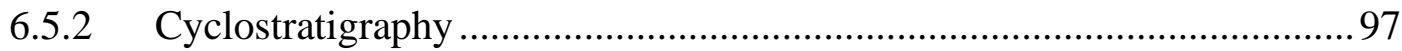

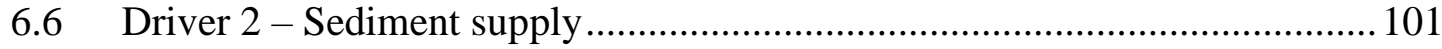

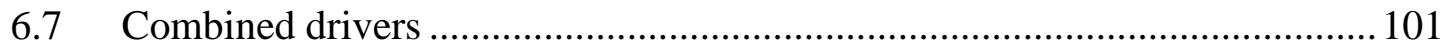

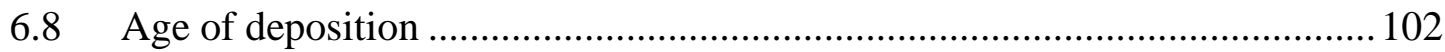

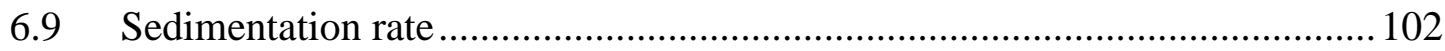

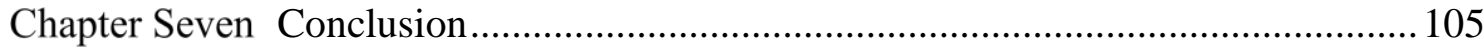

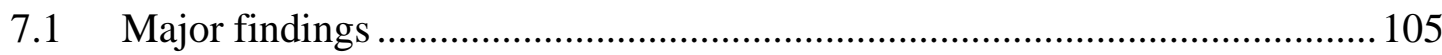

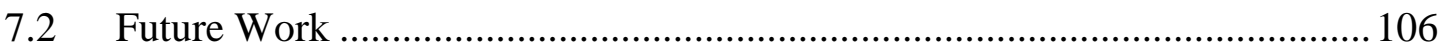

References

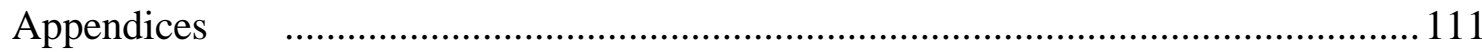




\section{List of Figures}

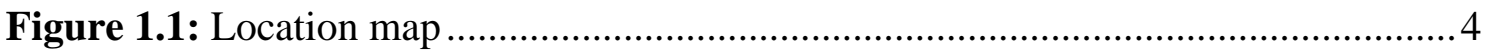

Figure 1.2: Regional tectonic setting of New Zealand................................................5

Figure 1.3: 3-D representation of the tectonic setting of the Wairarapa........................ 6

Figure 1.4: Paleogeography of the lower North Island during the early Nukumaruan

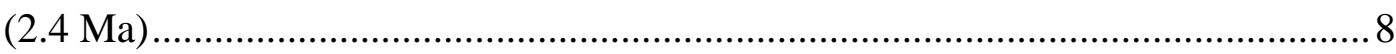

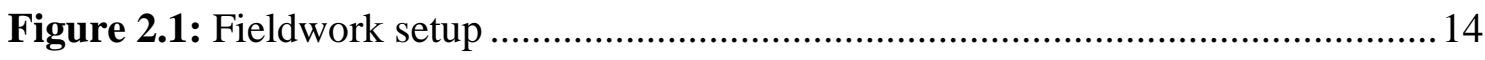

Figure 3.1: Previous uses of formation names and their associations. .......................... 17

Figure 3.2: Stratigraphic column for the Pukenui Limestone type section................... 23

Figure 3.3: Stratigraphic column for the Hautotara Formation type section .................. 33

Figure 4.1: Hinakura Road measured section showing station numbers ...................... 40

Figure 4.2: Greycliffs Formation and Unit 1 photographs ......................................... 42

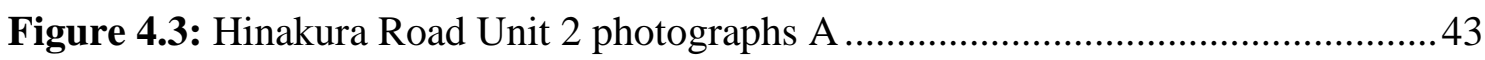

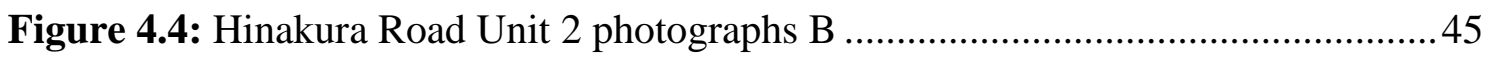

Figure 4.5: Hinakura Road Unit 3 photographs A ................................................... 47

Figure 4.6: Hinakura Road Unit 4 photographs A .....................................................49

Figure 4.7: Hinakura Road Unit 4 photographs B .................................................... 51

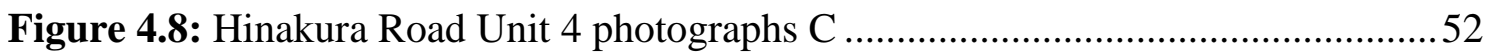

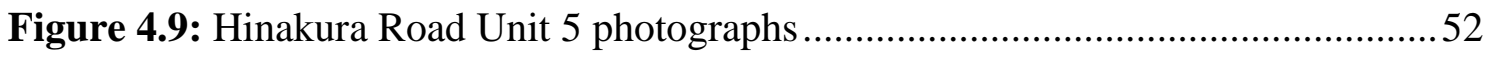

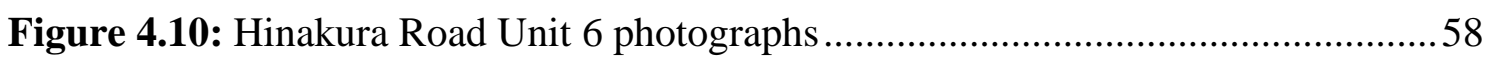

Figure 4.11: Longbush Road measured section showing station numbers ...................58

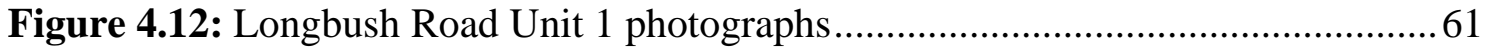

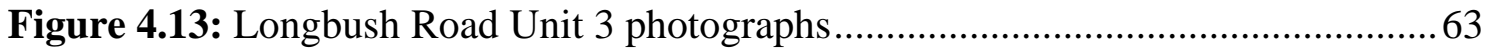

Figure 4.14: Colour change observed in outcrop at the Popes Head area ....................65

Figure 4.15: Geological map of the Popes Head area, showing Hinakura Road (HR) and Longbush Road (LR) measured sections

Figure 5.1: Non-fossiliferous sandstone $\left(\mathrm{S}_{\mathrm{N}}\right)$ facies at the Longbush Road measured section

Figure 5.2: Dosinia sandstone $\left(\mathrm{S}_{\mathrm{D}}\right)$ facies at the Hinakura Road measured section...... 70

Figure 5.3: Coarse sandstone $\left(\mathrm{S}_{\mathrm{C}}\right)$ facies at the Hinakura Road measured section ....... 71

Figure 5.4: Alternating fine sandstone and mudstone of the $S_{S / M}$ from Unit 2 of the Hinakura Road measured section 
Figure 5.5: Beds of sandy mudstone $\left(\mathrm{M}_{\mathrm{S}}\right)$ facies interbedded with conglomerate at the Longbush Road measured section.

Figure 5.6: Austrovenus shellbed $\left(\mathrm{SB}_{\mathrm{A}}\right)$ of Unit 2 at the Hinakura Road measured section

Figure 5.7: Tawera Shellbed from the top (A) and bottom (B) of HR26 (Enclosure A), Unit 4, Hinakura Road representing facies $\mathrm{SB}_{\mathrm{T}}$. .78

Figure 5.8: Conglomerate from $C$ facies are the Hinakura Road measured section. Coloured layer to left of hammer is tephra .80

Figure 6.1: Schematic representation of facies recorded in the Hinakura and Longbush Road measured sections .84

Figure 6.2: Deposition as it would have occurred at the Hinakura Road section, representing a relative sea-level fall due to tectonic uplift, and transition from fully marine to fully terrestrial deposition .87

Figure 6.3: Diagram showing correlations made between Hinakura Road measured section and type section for the Pukenui Limestone and Hautotara Formation......93

Figure 6.4: Diagram representing deposition related to sea-level and tectonics at the type locality for the Pukenui Limestone, Hautotara Formation, and Te Muna Formation

Figure 6.5: Diagram representing deposition related to sea level and tectonics at the Popes Head area for the Pukenui Limestone, Hautotara Formation, and Te Muna Formation .99

\section{List of Tables}

Table 2.1 Taphonomic attributes used to describe macrofossils in outcrop for this study, adapted from Hendy et al., 2006 16

Table 5.1: Tabular summary of facies. .82 


\section{Chapter One Introduction}

\subsection{General introduction}

The Pukenui Limestone Formation is an early to mid-Nukumaruan (2.40-1.63 Ma) sequence of limestones, sandstones, mudstones, and other minor lithologies, outcropping from the Aorangi Range in the Southern Wairarapa to Mangamahoe Road northeast of Mauriceville in the north (Beu, 1995). It is considered part of the Onoke Group, a complex series of limestones and other sedimentary units which can be found along the east coast of the North Island from the Southern Wairarapa to Hawkes Bay (Beu, 1995). The limestone covers an area approximately $80 \mathrm{~km}$ long and $6 \mathrm{~km}$ wide (Beu, 1995; Dobbie, 1982).

The type section, at Birch Hill (PL, Fig. 1.1) near the southern end of the Nga-Waka-AKupe Range (Fig. 1.1, ridgeline shown by Windy Peak Anticline, WPA), comprises three limestone members informally referred to as, in ascending order, limestone members A, B, and C (this study, following Nowland, 2011). The limestones are typically hard coquina beds, well-cemented and with abundant macrofossil content. Post-depositional carbonate diagenesis is evident in all members of the Pukenui Limestone. The three coquina beds are separated by the A-B and the B-C Interbeds which are typically sandy mudstones with patchy macrofossil content. Each limestone member contains roughly the same assemblage of molluscan macrofossils, and there is no species unique to any member. The base of the Pukenui Limestone is placed at a dense layer of Psychrochlamys delicatula (large scallop), and Tawera subsulcata (small Venus clam) is abundant in a highly cemented layer at the top of the $\mathrm{C}$ limestone, but both species can be found throughout other members and other units in the area (Beu, 1995).

The overlying Hautotara Formation is an estuarine and shallow marine unit typically identified at the base by a sharp change from a hard coquina to a medium sandstone lithology and an influx of Zethalia zelandica (small wheel shell). The Hautotara 
Formation is generally interpreted as representing the transition from the marine Pukenui Limestone below to the terrestrial Te Muna Formation above (Gammon, 1995). Post-depositional carbonate cementation has occurred within this unit, although not to the extent seen in the Pukenui Limestone, and is limited to coquina beds (Vella \& Briggs, 1971; Collen \& Vella, 1984). At the southern end of the range near Hautotara Bridge (Fig. 1.1) there are occasional coquina beds in the Hautotara Formation, however, due to strong lateral variability they are not as obvious at the northern end. Due to their similar appearances, the coquina beds of the Pukenui Limestone and Hautotara Formation are difficult to separate.

At the northern end of the Nga-Waka-A-Kupe Range the Pukenui Limestone and Hautotara Formation are represented by a different suite of lithologies than are seen at the respective type sections. Outcrops of typical lithologies of the underlying Greycliffs Formation and overlying Te Muna Formation are observed, but between them the observed lithology is extremely sandy and individual limestone units are not clearly recognisable. At many locations near the intersection of Cannock Road and Hinakura Road (Fig. 1.1), sandstones and coquinas of the Hautotara Formation are difficult to distinguish from sandstones and coquinas of the Pukenui Limestone. This dramatic change in lithology has occurred over less than the $10 \mathrm{~km}$ that separates the two locations. The Pukenui Limestone in the northern area of the Nga-Waka-A-Kupe Range displays rapid local lateral variation (Rampton, 1997), and this project focuses primarily on the complex stratigraphy of this locality.

\subsection{Aims}

At the southern end of the Nga-Waka-A-Kupe Range, a transition from marine to terrestrial sediments is documented in three early Pleistocene units. The fully marine Pukenui Limestone is overlain by the marginal marine Hautotara Formation, which is in turn capped by the terrestrial Te Muna Formation (Gammon, 1995). $10 \mathrm{~km}$ north, at the northern end of the range, a depositional change has occurred, causing units between the hard base of the Pukenui Limestone and the river gravels of the base of the Te Muna Formation to be almost lithologically indistinguishable. 
The aims of this project are:

A. Determine what depositional change occurred along the Nga-Waka-A-Kupe Range that caused this facies change. This will be accomplished by:

1. Documenting the lithostratigraphy and macropaleontology of two long measured sections at the northern end of the range

2. Integrating the lithostratigraphic and paleontological data to determine the paleoenvironment

3. Comparing the results to the well-documented sections at the southern end of the range

\subsection{Field Area}

The area of research for this study is located approximately $10 \mathrm{~km}$ southeast of Martinborough in the Southern Wairarapa. The field area is approximately $20 \mathrm{~km}^{2}$, which includes two measured sections and the areas that surround them (Fig. 1.1).

The two main road cuttings are located on Hinakura Road (HR) and Longbush Road (LR) (Fig. 1.1). These outcrops were chosen for the following reasons: While stratigraphically equivalent to the Pukenui Limestone and Hautotara Formation, the facies present in both outcrops appear unrelated to those found at the respective type sections. Both study outcrops are easily accessible and provide mostly continuous exposure. The type sections for the represented units are not far from the study area, and are well-documented, allowing for easy comparisons.

While not actively included in the field area, data from the southern end of the NgaWaka-A-Kupe Range is included. This forms the main point of comparison for the data collected in this study. 


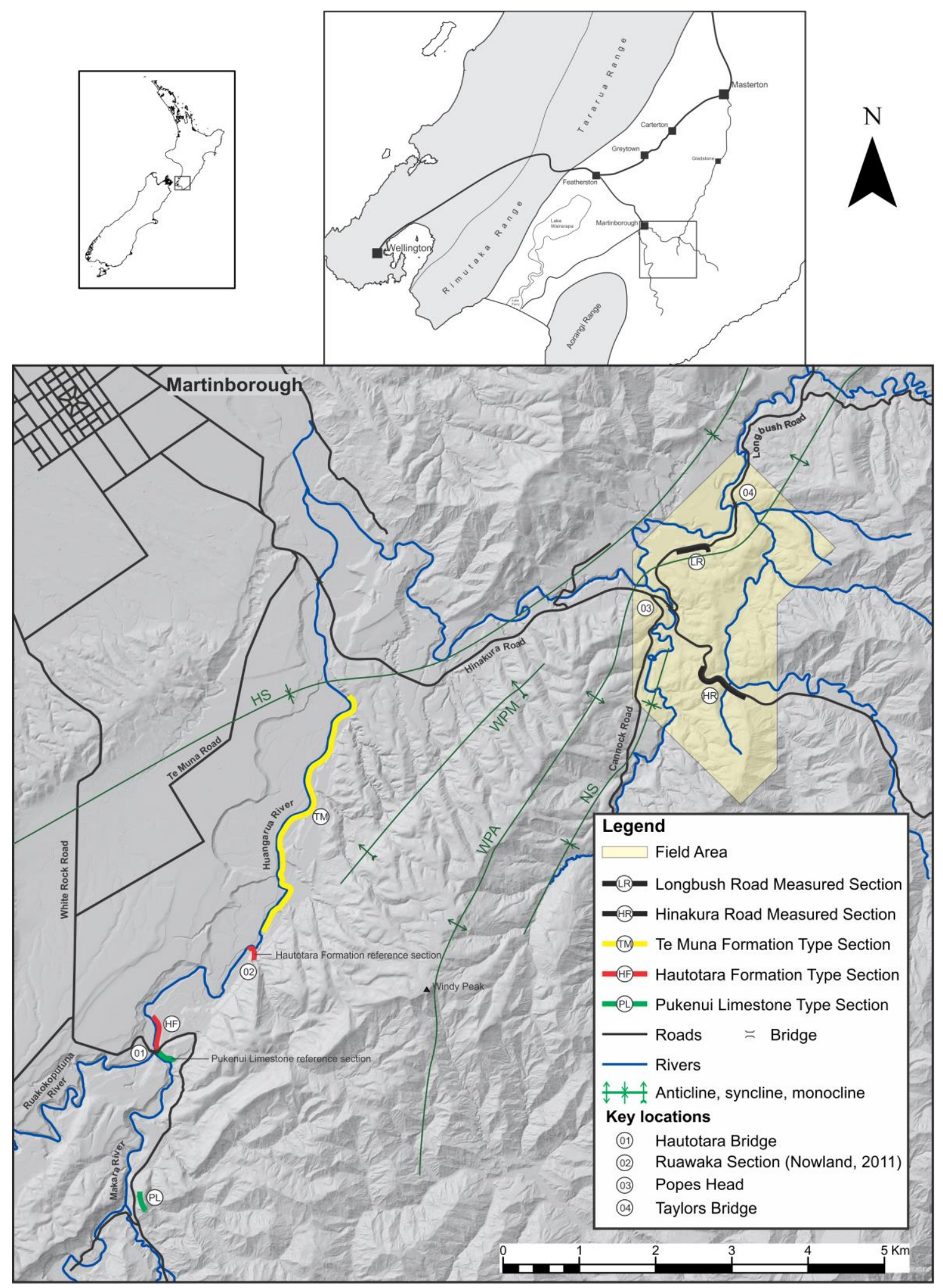

Figure 1.1: Map showing the location of both relevant measured section outcrops in the field area in relation to the wider Wairarapa area and New Zealand. Included are formation type sections, reference sections, and key locations. Green abbreviations refer to structures from left to right: HS - Huangarua Syncline, WPM - Windy Peak Monocline, WPA - Windy Peak Anticline, NS - Ngarara Syncline. The Windy Peak Anticline runs along the ridge of the Nga-Waka-A-Kupe Range until it ends to the north at Hinakura Road. PL (Pukenui Limestone type section) also refers to Birch Hill. 


\subsection{Geological setting}

The Wairarapa is located adjacent to the Hikurangi Margin subduction zone (Fig. 1.2). Here the Pacific Plate oceanic crust is subducting beneath the continental crust of the Australian Plate, converging obliquely at $\sim 40 \mathrm{~mm} / \mathrm{yr}$ (Fig. 1.2; Little et al., 2009). This activity began c. $20 \mathrm{Ma}$ (Nicol et al., 2002). As a result of the convergent plate boundary, compressional forces affect the Wairarapa. The Wairarapa Fault is a dextral strike-slip fault with a component of uplift that runs along the western edge of the Wairarapa at the base of the Rimutaka Ranges. The Rimutaka and other ranges flanking the Wairarapa are made up of highly deformed basement rocks, Mesozoic indurated sandstones and mudstones of the Pahau Terrane.

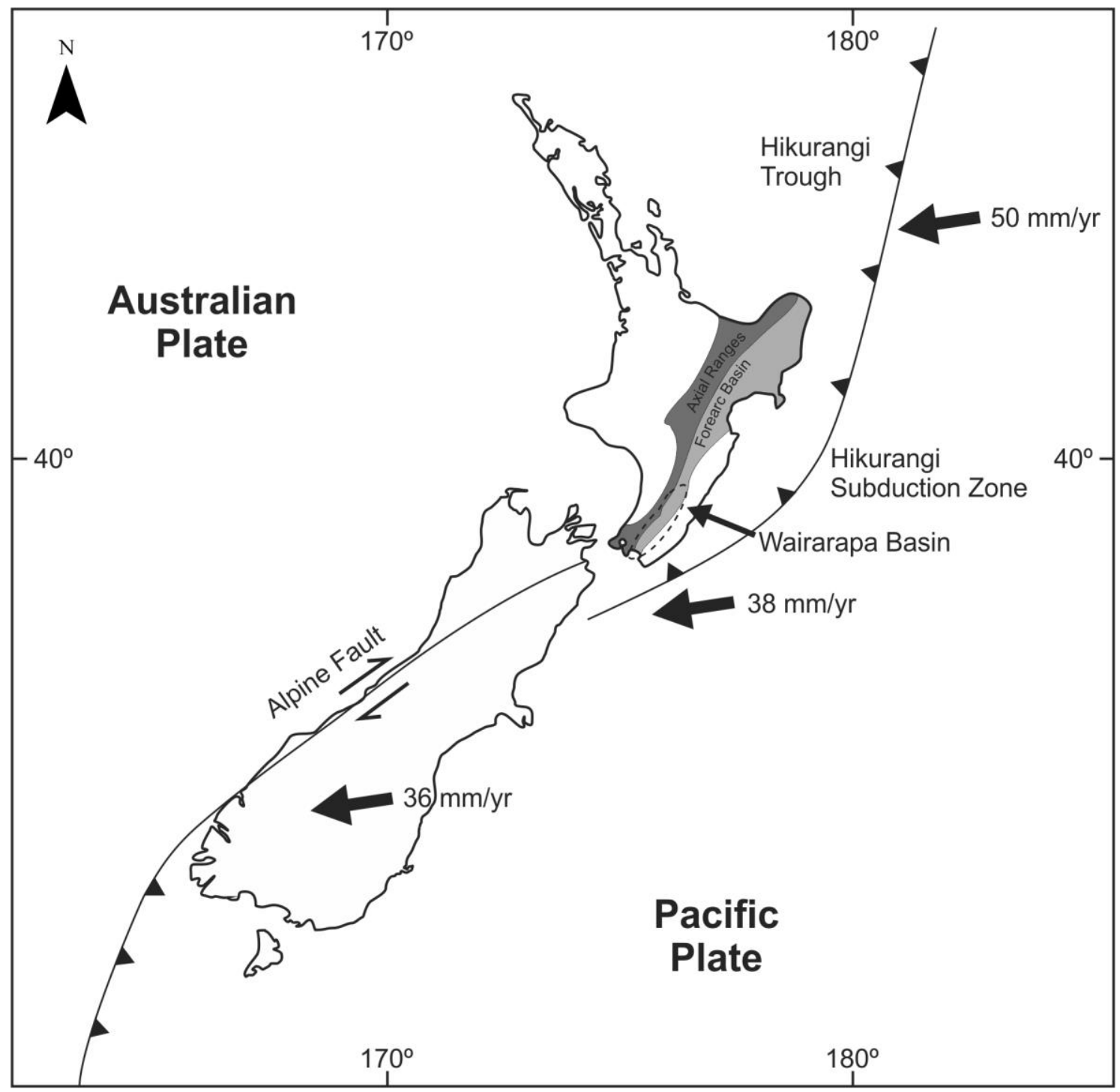

Figure 1.2: Regional tectonic setting of New Zealand, showing relative plate tectonic movements (modified from Lee \& Begg, 2002 and Little et al., 2009) 


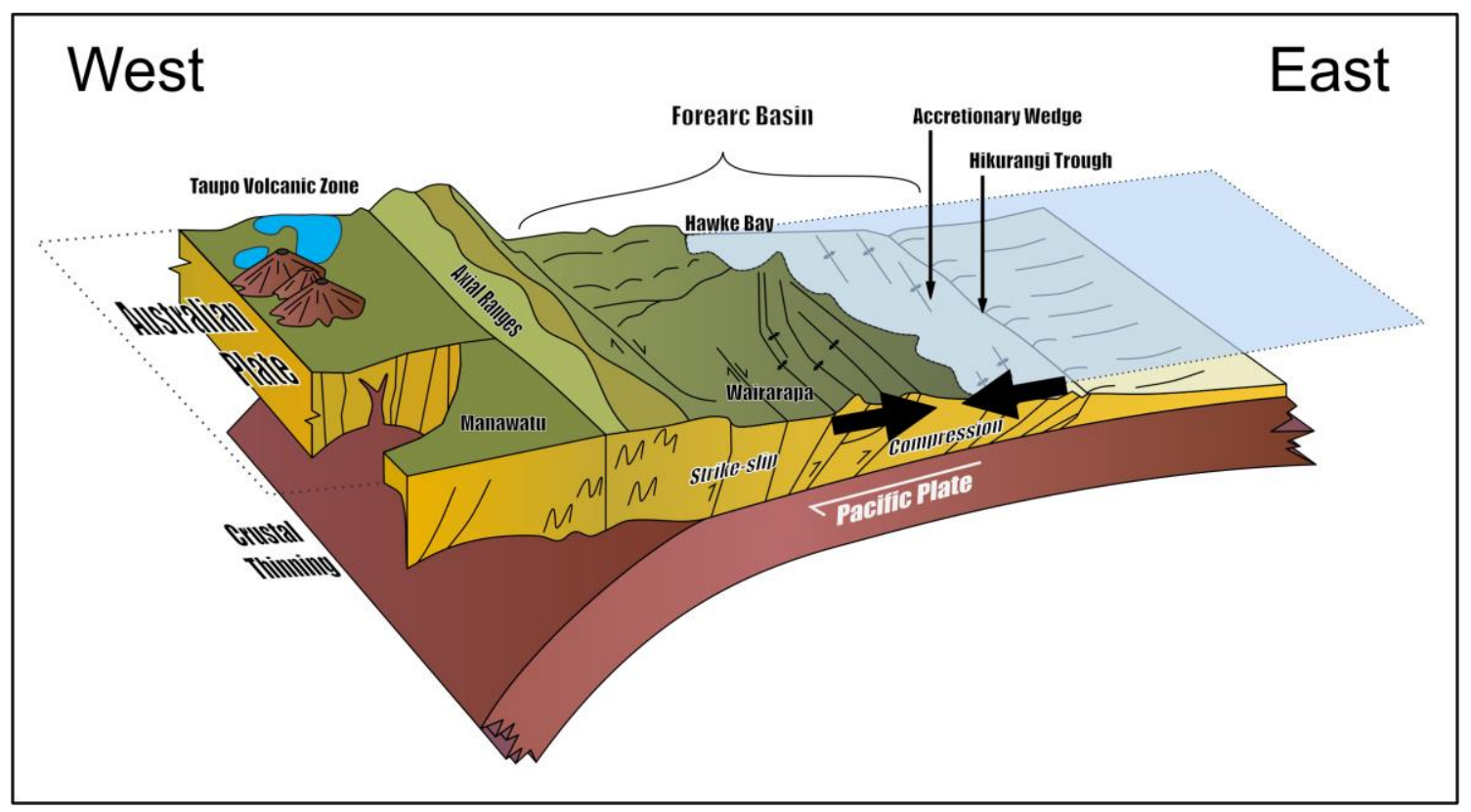

Figure 1.3: 3-D representation of the tectonic setting of the Wairarapa, showing the Pacific Plate subducting beneath the Australian Plate, resulting in deformation in the form of faulting and folding due to compression. Adapted from Lee and Begg (2002)

Accelerated deformation occurred during the latest Miocene and mid-Pliocene, lasting approximately two and one million years respectively (Nicol et al., 2002). The present deformation began c. 1.8 Ma. The last $10 \mathrm{~m}$.y. of deformation has been contractional, due to the convergence of the two tectonic plates.

The surrounding topography throughout southern Wairarapa is made up of small rolling hills and basins, which are commonly formed due to anticlines and synclines in Neogene sediments. Formation of the Windy Peak Anticline and Ngarara Syncline (Fig. 1.1) began during deposition of the Pukenui Limestone (Rampton, 1997). Deformation then shifted westward, forming the Windy Peak Monocline and Huangarua Syncline.

The Windy Peak Anticline is the main structural feature of the field area, dominating the landscape, and forms the Nga-Waka-A-Kupe Range. The anticline plunges to the northeast and is composed of Plio-Pleistocene sediments. Associated with this anticline is the Windy Peak Monocline, on the west flank of the anticline. The Ngarara Syncline flanks the eastern side of the anticline, and the Huangarua Syncline flanks the western side of the monocline. Both synclines also trend northeast/southwest. 
The most significant fault in this area is the Huangarua Fault, located to the west of the Huangarua Syncline (Begg \& Johnston, 2000). There are numerous other small faults present in and around the broader area, which do not significantly affect the study sections.

The Pukenui Limestone was deposited on the eastern side of the Ruataniwha Strait (now the Wairarapa Plains) which ran from South Wairarapa near present-day Palliser Bay to Hawke's Bay (Fig. 1.4; Trewick \& Bland, 2012). The strait was bounded on the west by the Rimutaka, Ruahine, and Tararua Ranges and to the east by the Aorangi Ranges and East Coast Ranges. Conditions in the strait during deposition of the Pukenui Limestone ( 2 Ma) have been compared to the modern-day Foveaux Strait between the South Island and Stewart Island (Dobbie, 1982).

Sea temperatures in the Ruataniwha Strait cooled prior to the deposition of the Pukenui Limestone, indicated by the presence of cold-water species such as Psychrochlamys delicatula which first appear in the Mangaopari Mudstone (underlying the Greycliffs Formation), and Jacquinotia edwardsii (giant spider crab) first appearing in the Greycliffs Formation (Orpin, Gammon, Naish, \& Carter, 1998). At a first-order scale, fluctuating sea-level was responsible for the deposition of the limestones and interbeds, with periods of low sea level depositing the limestone beds and periods of high sea level depositing the clastic interbeds. Additionally, tectonism in the area played a role in controlling the deposition of the local limestones, by influencing the terrigenous sediment supply rates (Atkins \& Collins, 2015). Tectonism was also responsible for the shift from marine to terrestrial formations. Throughout the Plio-Pleistocene unidirectional uplift resulted in apparent shallowing throughout each unit, eventually leading to the change from marine to terrestrial deposition as the Ruataniwha Strait emerged. 


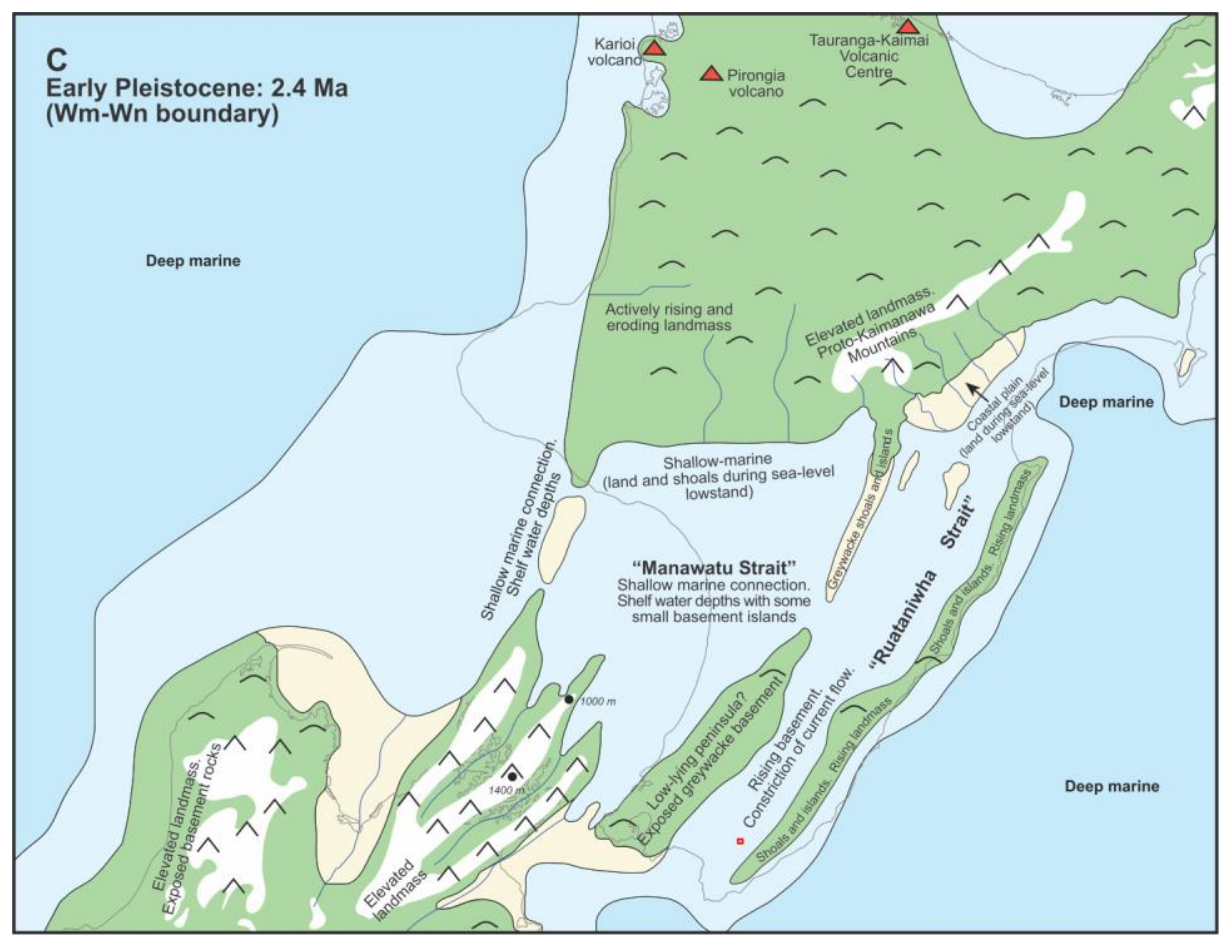

Figure 1.4: Paleogeography of the lower North Island during the early Nukumaruan (2.4 Ma), from Trewick and Bland (2012). Red square indicates field area.

\subsection{Previous work}

A significant number of geological studies have been completed in the southern Wairarapa dating as far back as the late $19^{\text {th }}$ century. These include a number of scientific papers, but predominantly Masters theses from Victoria University of Wellington (VUW), with a majority being undertaken at the southern end of the NgaWaka-A-Kupe Range. Extensive lithologic, stratigraphic, and paleontologic studies on the Pukenui Limestone, Hautotara Formation, and adjacent units have been conducted around the type sections and in areas such as the Ruakokoputuna and Makara Rivers. Little work has been completed on the Pukenui Limestone and Hautotara Formation equivalents at the northern extent of the range.

The earliest work in the area was carried out by Crawford (1871) and McKay (1878, 1879), who provided general observations of the Wairarapa Tertiary sediments north of the Aorangi Range. Several studies in the early $20^{\text {th }}$ century placed a greater focus on paleontology. These include Thomson (1919), Waghorn (1926) and King (1933). King (1933) defined two lithostratigraphic "Series": the Late Miocene Hurupi and Plio- 
Pleistocene Onoke Series. The Onoke Series has since been elevated to a group by Vella and Briggs (1971) and includes sediments covered in this thesis. Waghorn (1926) and King (1933) produced several early faunal lists from an assortment of formations in areas relevant to this study.

Couper (1948) mapped an area due south of Martinborough around the Ruakokoputuna and Makara Rivers, including a 'Hautotara Formation' which included the modern Greycliffs through Te Muna Formations. Due to a misunderstanding of the local geological structure, Couper recognised eight limestones where the Ruakokoputuna and Makara Rivers meet, which was modified by Rodley (1961) to six.

In his 1949 Master's thesis, Paul Vella studied an area that overlaps the area covered in this study. His thesis mapped and described sediments in the Hinakura District, with particular attention to macrofossil assemblages. After his MSc, Vella conducted almost fifty years of geologic research in the Wairarapa, publishing numerous papers with a focus on sedimentology and paleontology. His research is particularly relevant to this thesis.

The bulk of the macrofossil analysis was carried out by Vella $(1953 ; 1954)$ in a detailed analysis of the Plio-Pleistocene strata. Vella (1953) defined five biostratigraphic zones along the Makara Stream using six species of the genus Pelicaria. The zones are no longer applicable, as the six species of Pelicaria have since been shown to be morphotypes of Pelicaria vermis (Neef, 1970; Beu, 2010)

Geology surrounding the convergence of the Ruakokoputuna and Makara Streams was studied by Rodley (1961). Her geological and paleontological work on the local sediments has been used by many of the researchers who came after her. Rodley (1961) used the Pelicaria zones defined by Vella (1953) to correlate two of the limestones identified by Couper (1948). This reduced the number of limestone to six, which Rodley (1961) included in her interpretation of the Hautotara Formation.

Vella (1963a) used cyclothems to explain repeated lithological patterns observed in Plio-Pleistocene sediments. Vella continued using cyclothems to define sedimentary packages in his following publications rather than using the formal lithostratigraphic unit. 
Several units, including the Pukenui Limestone, were formally defined for the first time by Vella and Briggs (1971). A sequence of twelve upper Cenozoic (MiocenePleistocene) units were described, the youngest being the Pukenui Limestone. Vella \& Briggs (1971) discussed lithostratigraphic and interfacies relationships, including ages and biostratigraphic zones.

An important and particularly useful MSc thesis was completed by Dobbie (1982), which investigated the sedimentology and diagenesis of the Pukenui Limestone over a larger area than any other study. Dobbie (1982) identified the Foveaux Strait (between the South Island and Stewart Island) as a modern analogue for the depositional environment of the Pukenui Limestone. Other areas of importance were the relationship between deposition and tectonism, as well as how terrigenous content affects carbonate deposition. Both are important to this study.

Collen \& Vella (1984) extended on the work of Vella \& Briggs (1971) by formally describing for the first time the three units immediately above the Pukenui Limestone. These were the Hautotara, Te Muna, and Ahiaruhe Formation. They interpreted the facies as indicating basin emergence, to the point where deposition was non-marine.

Rataul's (1988) study focused on the Hautotara and Te Muna Formations, but she also included the Pukenui Limestone. With the original type section of the Hautotara having been mostly obscured by earthworks, her thesis described additional areas to supplement the original type section. Environments of deposition were described for the Hautotara and Te Muna Formations, with an indication of age and tectonic activity.

Foraminifera and magnetostratigraphy of the late Neogene were studied by Edwards (1987). The magnetostratigraphy has been useful as an additional means for confining the age of the Pukenui Limestone and its associated members.

The geological structure of the Wairarapa Valley was mapped using seismic reflection profiling by Cape et al. (1990). One focus area of their study was the Huangarua Syncline, near the type section of several formations included in this study. They interpreted the Hautotara Formation as increasing in thickness from $35 \mathrm{~m}$ near the type section to $>100 \mathrm{~m}$ at the northern extent of the Huangarua Syncline. 
Beu (1995) conducted an in-depth review of Pliocene limestones from the eastern North Island, including revising stratigraphic nomenclature, covering lithostratigraphy, paleogeography, and biostratigraphy. He compiled material from all of the eastern North Island limestones and the fauna found within.

The sequence stratigraphy within the Hautotara Formation was studied by Gammon (1995). His study included identifying a minimum of five glacio-eustatically controlled cycles and recognising that the formation represents a regression from marine to nonmarine. He further reinterpreted the type section and proposed a new reference section. Gammon (1995) revised the Pukenui Limestone/Hautotara Formation contact, placing it at the top of the 'Limestone C' used in this study.

Detailed analysis of the Pukenui "A" Limestone was carried out by Atkins in his Honours thesis (1995), with a focus on the depositional environment. His study included informally redefining the base of the Pukenui Limestone to that used in subsequent studies, including this one. The new boundary is easier to observe in the field, greatly aiding mapping the Pukenui Limestone. Atkins (1995) observed that lower units of the Pukenui Limestone show significant lateral variation, particularly thickness.

A Master's thesis notably relevant to this one with a focus on the Late Neogene geology along the Ngarara and Huangarua Rivers was completed by Rampton (1997). The stratigraphy studied in his thesis extended from the Mangaopari Mudstone up to the Ahiaruhe Formation, including the formations covered in this study. He provided evidence that the tectonic deformation producing the Windy Peak Anticline began during deposition of the Pukenui Limestone. Although not as detailed as other studies conducted in the area, Rampton's (1997) thesis provides depositional environments for each of the units studied, as well as links to tectonic activity.

Biostratigraphy, lithostratigraphy, and a series of biofacies were used to infer depositional environments within the Pukenui Limestone by Clarke (1998). Relative sea-level curves were produced for each of his measured sections. Clarke's work further noted the growth of the Windy Peak Anticline during the deposition of the Pukenui Limestone.

Andrews (2001) studied the geology of outcrops along Hinakura and Longbush Road, including outcrops and mapping areas included in this study. Her honours thesis 
investigated the depositional environment of the Pukenui Limestone in a similar manner to this study. Due to several constraints such as a lack of structural data and biostratigraphic markers, Andrews (2001) did not correlate her work with the type section.

A study of the emergence of the southeastern Wairarapa was completed by Nowland (2011) by analysing in detail the facies and sequence architecture of the Hautotara and Te Muna Formations. Nowland further used microfossils, tephra, and calculated cycles to constrain ages for contacts and formations. 


\section{Chapter Two \\ Methods}

\subsection{Fieldwork}

Fieldwork for this thesis was carried out between February of 2018 and July of 2019. Data collection was by detailed section logging of chosen outcrops, and mapping the surrounding area.

\subsubsection{Measured section}

Sections were measured and logged using tape \& compass (Fig. 2.1). Where required the outcrop was cleared using a spade. A 50 m measuring tape (base tape) was laid down at the base of the outcrop along the road, with the $1 \mathrm{~m}$ mark at the point where logging was set to begin ( $1 \mathrm{~m}$ of the tape was wrapped around a hammer to anchor it to the ground). Bearing and inclination of the tape were recorded at the beginning, and at each point where values changed. At $49 \mathrm{~m}$ (50 m on the tape, less the $1 \mathrm{~m}$ attached to hammer), the tape was laid out again, starting with $1 \mathrm{~m}$ at the previous $49 \mathrm{~m}$ mark (Station 1, 2, 3 etc.). Outcrop descriptions are often small and frequent, requiring a second tape measure placed on the outcrop, perpendicular to the dip of the beds. The distance along and height above the base tape was recorded, and the measurements used to calculate stratigraphic height. 


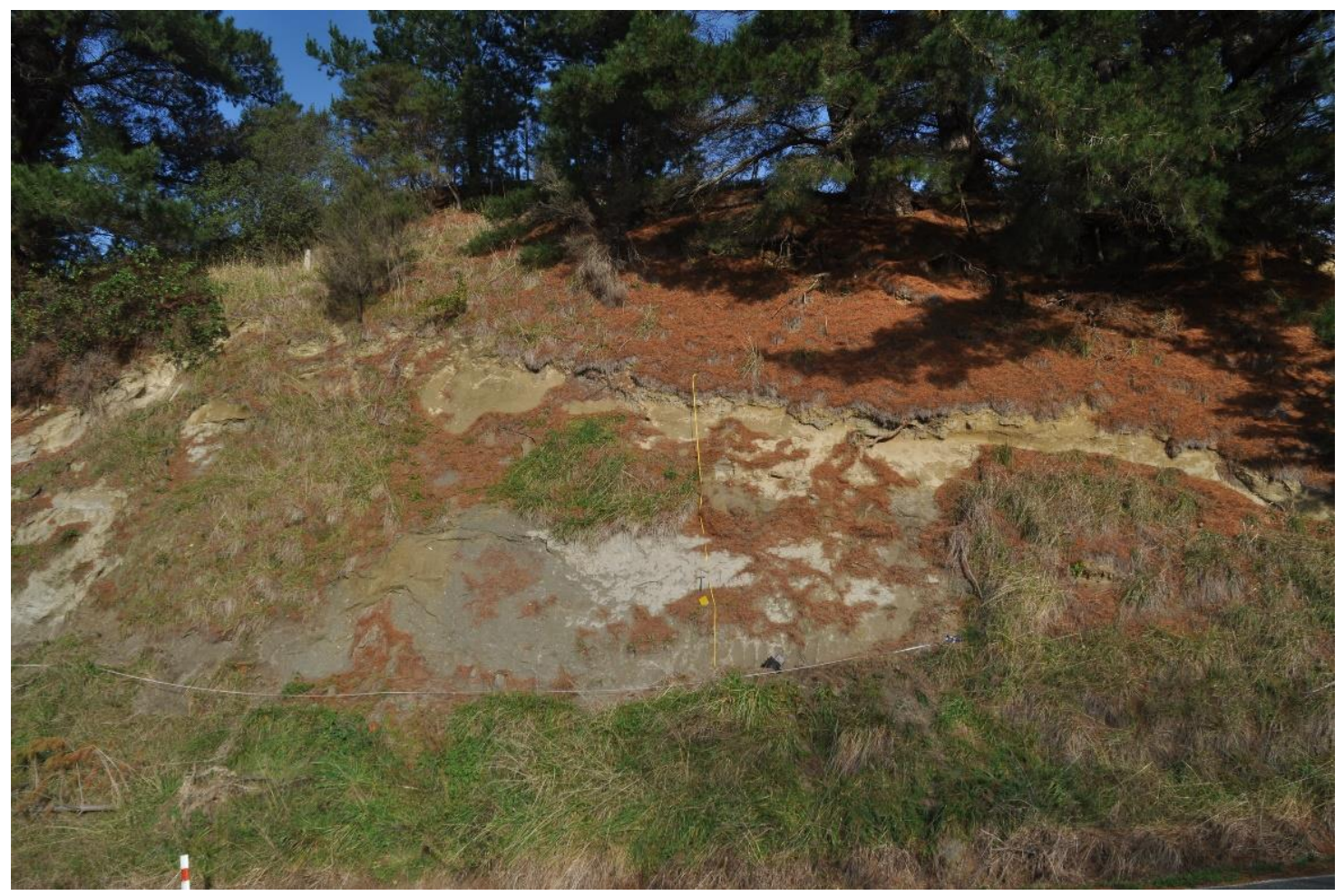

Figure 2.1: Fieldwork setup. Photograph showing horizontal (white) and vertical (yellow) tape measure setup. Vertical tape is showing $5 \mathrm{~m}$ of outcrop at $16.9 \mathrm{~m}$ along Station 9 tape (photograph from Ben Hines).

Each data point (distance along and above the tape, bearing and inclination of tape, strike and dip of outcrop) was input into a spreadsheet (Crampton, 2019, pers. comms) which calculated the stratigraphic height of each description. Due to slight errors in measurements, vertical sections sometimes overlapped. In this case, adjustments had to be made manually.

The tape \& compass method was chosen for several reasons. Mistakes are accounted for and can easily be corrected without having to remeasure any of the sections. Having section data in this standardised format allows sections to be double-checked, re-logged in greater detail if needed, more samples to be taken, and subsequently easily integrated with existing data.

Lithology, colour, grainsize, sorting, sedimentary structures, bedding, and fossil data were described in the field. This meant splitting the outcrop into as many different horizons as possible. No single criterion was used to differentiate between, and the 
thickness of each varied. A new horizon was defined when any observable change occurred in outcrop. Changes taken into account were usually grainsize and faunal abundance or content. Grainsize was determined in the field using a hand lens and grainsize comparator. Changes had to be easily observable in-field to be considered a new horizon.

\subsubsection{Mapping}

The field area was mapped using GPS and plotted in ArcMap. Due to a lack of outcrop exposure there was difficulty linking the Hinakura and Longbush Road outcrops to one another. Much of the surrounding map was inferred using local structure and topography.

\subsection{Macropaleontology}

Macrofossils were identified in the field. Those that could not were photographed in outcrop and location recorded, before being extracted from the outcrop for later comparison. Due to the friable nature of the outcrop and its state of calcification, many specimens disintegrated when touched. Only examples from well-cemented shellbeds or concretions could be easily and consistently removed.

Macrofossil content was described in-field using a method from Hendy et al. (2004), which included nine taphonomic attributes. A table of these attributes with associated values is included (Table 2.1). Each attribute has five values (1-5), except for abrasion which only has four (2-5). The range, value, and what it determines is specific to each attribute.

Initially, all attributes were used, however, several were discarded due to a lack of application. Abrasion and bio-erosion were difficult to determine in field and were therefore rarely used. Cementation was fairly consistent throughout the sections measured, and therefore was not always recorded. 
Table 2.1 Taphonomic attributes used to describe macrofossils in outcrop for this study, adapted from Hendy et al., 2006

\begin{tabular}{|c|c|c|c|c|c|c|}
\hline $\begin{array}{l}\text { Taphonomic } \\
\text { Attributes }\end{array}$ & & 5 & 4 & 3 & 2 & 1 \\
\hline Packing & $P$ & $\begin{array}{l}\text { Very dense } \\
\text { (skeletal material bioclast } \\
\text { supported) }\end{array}$ & \begin{tabular}{|l|} 
Dense \\
(most skeletal material bioclast \\
supported)
\end{tabular} & $\begin{array}{l}\text { (Skeletal material may be } \\
\text { bioclast or matrix supported) }\end{array}$ & $\begin{array}{l}\text { Loose } \\
\text { (skeletal material matrix } \\
\text { supported) }\end{array}$ & $\begin{array}{l}\text { Dispersed } \\
\text { (skeletal material isolated } \\
\text { within matrix) }\end{array}$ \\
\hline Sorting & $s$ & $\begin{array}{l}\text { Very good } \\
\text { (skeletal material very well } \\
\text { sorted) }\end{array}$ & $\begin{array}{l}\text { Good } \\
\text { (skeletal material well sorted) }\end{array}$ & $\begin{array}{l}\text { Moderate } \\
\text { (skeletal material poorly sorted) }\end{array}$ & $\begin{array}{l}\text { Poor } \\
\text { (skeletal material poorly sorted) }\end{array}$ & $\begin{array}{l}\text { Very poor } \\
\text { (skeletal material very poorly } \\
\text { sorted) }\end{array}$ \\
\hline Fragmentation & $\mathrm{F}$ & $\begin{array}{l}\text { Very high } \\
\text { (all skeletal material } \\
\text { fragmented) }\end{array}$ & $\begin{array}{l}\text { High } \\
\text { (fragmented skeletal material } \\
\text { dominant) }\end{array}$ & $\begin{array}{l}\text { Moderate } \\
\text { (mixture of fragmented and } \\
\text { complete skeletal material) }\end{array}$ & $\begin{array}{l}\text { Some } \\
\text { (complete skeletal material } \\
\text { dominant) }\end{array}$ & $\begin{array}{l}\text { None } \\
\text { (all skeletal material complete) }\end{array}$ \\
\hline Orientation & 0 & $\begin{array}{l}\text { Concave up } \\
\text { (concave-up orientated skeletal } \\
\text { material dominant) }\end{array}$ & $\begin{array}{l}\text { Convex up } \\
\text { (covex-up orientated skeletal } \\
\text { material dominant) }\end{array}$ & $\begin{array}{l}\text { In situ } \\
\text { (most skeletal material } \\
\text { orientated in life position) }\end{array}$ & \begin{tabular}{|l|} 
Mixed \\
(mixed concave-up, convex-up, \\
and perpendicular orientated)
\end{tabular} & $\begin{array}{l}\text { N/A } \\
\text { (orientation cannot be } \\
\text { determined) }\end{array}$ \\
\hline Disarticulation & $\mathrm{D}$ & $\begin{array}{l}\text { Very high } \\
\text { (all skeletal material } \\
\text { disarticulated) }\end{array}$ & \begin{tabular}{|l|}
$\begin{array}{l}\text { High } \\
\text { (disarticulated skeletal material } \\
\text { dominant) }\end{array}$ \\
\end{tabular} & $\begin{array}{l}\text { Moderate } \\
\text { (mixture disarticulated/ } \\
\text { articulated skeletal material) }\end{array}$ & $\begin{array}{l}\text { Some } \\
\text { (articulated skeletal material } \\
\text { dominant) }\end{array}$ & $\begin{array}{l}\text { Conjoined } \\
\text { (all skeletal material articulated) }\end{array}$ \\
\hline Abrasion & A & $\begin{array}{l}\text { High } \\
\text { (most skeletal material abraded) }\end{array}$ & \begin{tabular}{|l} 
Some \\
(abraided skeletal material \\
uncommon)
\end{tabular} & $\begin{array}{l}\text { None } \\
\text { (no abraded skeletal material) }\end{array}$ & $\begin{array}{l}\text { N/A } \\
\text { (abrasion cannot be determined) }\end{array}$ & \\
\hline Cementation & c & $\begin{array}{l}\text { Very high } \\
\text { (skeletal assemblage is hard } \\
\text { limestone, extremely difficult } \\
\text { to crush) }\end{array}$ & $\begin{array}{l}\text { High } \\
\text { (skeletal assemblage requires } \\
\text { some difficulty to crush) }\end{array}$ & $\begin{array}{l}\text { Moderate } \\
\text { (skeletal assemblage crushes } \\
\text { without difficulty) }\end{array}$ & $\begin{array}{l}\text { Some } \\
\text { (skeletal assemblage within } \\
\text { consolidated material, easy to } \\
\text { segregate) }\end{array}$ & $\begin{array}{l}\text { None } \\
\text { (skeletal assemblage } \\
\text { desegregates from matrix with } \\
\text { ease) }\end{array}$ \\
\hline Bioerosion & B & $\begin{array}{l}\text { Very High } \\
\text { (almost all skeletal material } \\
\text { contains surficial encrustation } \\
\text { and/or endolithic boring) }\end{array}$ & \begin{tabular}{|l|} 
High \\
(most skeletal material contains \\
surficial encrustation and/or \\
endolithic boring)
\end{tabular} & \begin{tabular}{l|} 
Moderate \\
(some skeletal material contains \\
surficial encrustation and/or \\
endolithic boring)
\end{tabular} & $\begin{array}{l}\text { Some } \\
\text { (surficial encrustation and/or } \\
\text { endolithic boring rarely } \\
\text { observed) }\end{array}$ & $\begin{array}{l}\text { None } \\
\text { (no evidence of encrustation or } \\
\text { endolithic boring) }\end{array}$ \\
\hline
\end{tabular}

Samples were collected approximately every metre where possible, and more often if greater resolution was required. A list of identified macrofossil species with photographs is shown in Appendix 2.

\subsection{Definitions}

Throughout this thesis the terms "coquina" and "shellbed" are used to refer to different deposits. Coquinas are defined by the American Geosciences Institute Glossary of Geology as "A detrital limestone composed wholly or chiefly of mechanically sorted fossil debris that experienced abrasion and transport before reaching the depositional site." A shellbed is defined as "an increase in the amount of shells within a horizon relative to the horizon above and below, not necessarily cemented or calcified." 


\section{Chapter Three \\ Type Section Stratigraphy}

\subsection{General Introduction}

The formations included in this study have been used for many years and the definitions applied to each have changed considerably in that time. Figure 3.1 shows the development of the lithostratigraphic nomenclature of the area since Rodley (1961). Of note is the significant changes to the original definition of the Pukenui Limestone (Vella \& Briggs, 1971) and the Hautotara Formation (Collen \& Vella, 1984), and the modern and most widely used definition (Nowland, 2011). This study follows most closely the stratigraphic framework set by Nowland (2011).

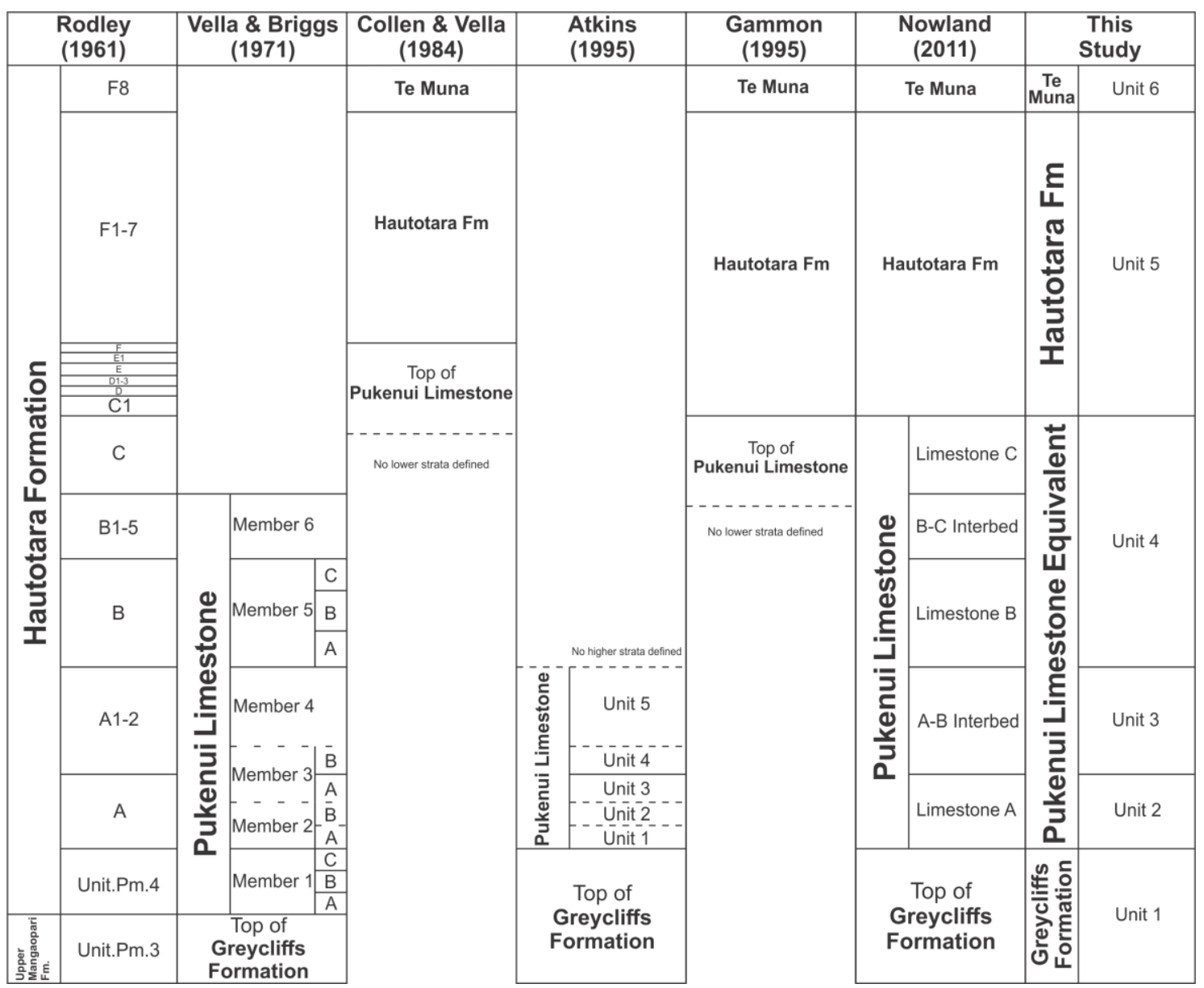

Figure 3.1 Previous uses of formation names and their associations, along with that used in this study. Not inclusive of all prior studies, only those relevant to this study. 
This chapter describes the Pukenui Limestone and Hautotara Formation as they are found at and around the type section, to provide a comparison for the more northern lithologies described in this thesis. It is a compilation of data from Honours theses, Masters theses, and scientific articles that have documented each lithology at the southern end of the Nga-Waka-A-Kupe Range. This level of detail is necessary due to the changing definition of each formation between different studies. An updated description of the type section area is required to represent each formation in the way that it is used by modern studies from VUW that haven't been formalised, and to compare to the units recorded in the field area included in this study.

Several features for each formation are described here. Firstly, the type section location is presented followed by a generalised description of the formation. A compilation of descriptions from multiple previous studies is used to produce a modern and updated description of the type area. Secondly, the contacts of each formation are described, followed by their distribution, including thickness. Paleontology, age, and environment of deposition are also discussed in detail here.

Figure 3.1 sets out how previous authors have defined the Plio-Pleistocene units around the Nga-Waka-A-Kupe Range. In a Masters study, Rodley (1961) included all sediments between what Nowland (2011) calls the Greycliffs Formation to within the Te Muna Formation, in the Hautotara Formation. As this was an unpublished Masters thesis the name Hautotara was informal, however the work completed by Rodley (1961) was used extensively by Vella and Briggs (1971) when they formally defined for the first time the Pukenui Limestone. Vella and Briggs (1971) redefined the bottom part of Rodley's (1961) Hautotara Formation, including the lower two limestones in a new unit they called the Pukenui Limestone. The base of the new unit was placed at the base of P.m.4 (Rodley, 1961), a sandstone underlying the lowermost coquina (Vella \& Briggs, 1971). Collen and Vella (1984) formally described the Hautotara Formation as units F1 to F7 of Rodley (1961), the highest cemented coquina bed (Limestone F of Rodley, 1961) being the lowermost unit. As shown in Figure 3.1 the two studies combined exclude Limestone $\mathrm{C}$ to Limestone $\mathrm{F}$ in either of the original formal descriptions. Subsequent studies are included as they represent the changes made to the interpretation of each of the formations and their respective boundaries. Of particular importance, an alternative lower contact for the Pukenui Limestone was described by Atkins (1995), 
modifying it from that defined by Vella and Briggs (1971) to the modern definition which is easier to identify in the field. Gammon (1995) is included in Figure 3 as he formally redefined the lower contact of the Hautotara Formation from Collen and Vella (1984) to its modern definition. The new formal definition was the top of Limestone C, the same contact now used by Nowland (2011). Also noted by Nowland (2011) was how the multiple coquina beds within both the Pukenui Limestone and Hautotara Formation are easily confused. The most widely used definition of the Pukenui Limestone is that shown in Figure 3.1, from Nowland (2011). The changes to each formations boundaries and why the respective author made the change are further detailed in sections 3.2.3 and 3.2.4 for the Pukenui Limestone, and 3.3.3 and 3.3.4 for the Hautotara Formation.

Rather than separate units based on observable changes such as lithology or macrofauna, sediments were divided by Vella and Briggs (1971) and Collen and Vella (1984) into complete cyclothems, each representing an entire glacio-eustatic sea-level cycle. This meant the "contact" between units was difficult to identify in the field, as it was often at a change that was unobservable to the naked eye.

\subsection{Pukenui Limestone}

\subsubsection{Type Section Location}

The Pukenui Limestone type section is located to the northeast of White Rock Road, opposite Birch Hill Homestead (Fig. 1.1) and was originally identified and described by Vella and Briggs (1971). They mapped cyclothems rather than formations, with the boundaries determined by inferred sea-level cycles which were not always easily observable in outcrop. The original definition of the Pukenui Limestone excluded the Limestone $\mathrm{C}$ that modern studies include as it was not considered part of the Eringa Cyclothem (Early Nukumaruan).

Nowland (2011) notes that the type section is now overgrown, and suggests other outcrops which are accessible and represent the Pukenui Limestone in its entirety as it is defined in modern studies. These outcrops are located in streams adjacent to the original type section, as well as in the Makara River upstream of its confluence with the Ruakokoputuna River (Fig. 1.1). 


\subsubsection{Generalised Pukenui Limestone Description}

This summary description of the Pukenui Limestone is a compilation from several previous authors who have described the original type section and other outcrops in the surrounding area following the original description from Rodley (1961), and formal description by Vella and Briggs (1971). It includes descriptions from proposed reference sections in Clarke (1998), Nowland (2011), and Anderson-Scott (2017). The description is from outcrops along the Makara River, immediately upstream of Hautotara Bridge (Fig. 1.1), as this is the most complete exposure of the Pukenui Limestone at the southern end of the Nga-Waka-A-Kupe Range (Rodley, 1961; Clarke, 1998; Nowland, 2011; Anderson-Scott, 2017). Other sections in the area provide additional material for specific members.

At its type section, the Pukenui Limestone is identified by Nowland (2011) as three mildly to moderately calcified coquina beds separated by calcareous muddy sandstones. These beds are labelled in ascending order: Limestones A to C, separated by Interbeds A-B and B-C (Figure 3.1). The official description of the Pukenui Limestone by Vella and Briggs (1971) contains six members each split into multiple sub-members. The description provided here does not directly correlate with the description provided by Vella and Briggs (1971), instead with the modern description by Nowland (2011). Section 3.2.4 describes the problem with the top contact, however the unit itself is described in this section.

Limestone $\mathrm{A}$ is an orange to brown coquina with calcification increasing upwards (Anderson-Scott, 2017). The base of the Limestone A is marked by an increase in the abundance of Psychrochlamys delicatula from sparse to well packed (Unit 1, Atkins, 1995). The shells are well preserved in a muddy sandstone matrix, predominantly disarticulated, and orientated with a mixture of concave up and concave down (Atkins, 1995; Clarke, 1998). The barnacle Austromegabalanus decorus is found on all sides of the majority of macrofauna (Clarke, 1998). The macrofauna in this unit, particularly Psychrochlamys delicatula, are typically found protruding from the outcrop. Rodley (1961) records this member as calcite cemented shelly sandstones and shellbeds with no observed pebbles. This member is approximately $7 \mathrm{~m}$ thick (Rodley, 1961; AndersonScott, 2017). 
The A-B Interbed is a blue-grey, massive, muddy sandstone, with a sharp lower contact (Rodley, 1961; Anderson-Scott, 2017). The lithology coarsens upwards, particularly near the upper contact with Limestone B, and concretionary bands become more prominent (Anderson-Scott, 2017). Macrofauna content is sparse, and bivalves are dominantly disarticulated and isolated within the matrix (Clarke, 1998). This member ranges between $16.5 \mathrm{~m}$ (Ruakokoputuna River, Rodley, 1961) and $29.5 \mathrm{~m}$ thick (Makara River, Anderson-Scott, 2017)

Limestone B is poorly exposed and weathered where it outcrops along the Makara River and surrounding areas (Clarke, 1998). Where exposure is recorded, a second orange to brown, well cemented, coquina interbedded with sandstone layers is described (Rodley, 1961; Anderson-Scott, 2017). Calcification and macrofossil content increases upwards. The faunal assemblage is similar to Limestone A, however less Psychrochlamys delicatula are present. Panopea zelandica (New Zealand geoduck) are more abundant than in underlying units, and Glycymeris shrimptoni (small dog cockle) make an appearance (Clarke, 1998). Shells are dominantly broken and worn, set within a matrix of coarse sandstone and shell fragments, in places bioclast supported (Rodley, 1961; Clarke, 1998). The recorded thickness for this unit varies greatly around the type section, from $4.5 \mathrm{~m}$ (Rodley, 1961) to $22.6 \mathrm{~m}$ (Vella \& Briggs, 1971).

The B-C Interbed is very similar to the A-B Interbed: blue-grey, moderately to wellsorted, muddy sandstone. Grainsize and faunal content increases upwards through the member, and concretionary layers are evident near the top. Faunal content is dominantly fragmented. Gastropods are scattered throughout the member, dominantly Stiracolpus symmetricus (small turret shell), and including Pelicaria vermis (ostrich foot shell) and Alcithoe brevis (large sea snail) in the top two metres (Clarke, 1998). Rodley (1961) identified Zethalia zelandica in the highest $4 \mathrm{~m}$. The top two metres marks an increase in cementation, bivalve fragments, and whole bivalves although still matrix-supported, including disarticulated Panopea zelandica and Tawera subsulcata (Clarke, 1998). The B-C Interbed is approximately $17 \mathrm{~m}$ thick at the type section (Rodley, 1961; Clarke, 1998; Anderson-Scott, 2017), with one anomalous measurement of $29.2 \mathrm{~m}$ at Woolshed Creek (Anderson-Scott, 2017).

The lower section of Limestone $\mathrm{C}$ is an orange to brown sandy coquina similar to the other coquina members. The macrofossil content is similar to Limestone B, with the 
addition of Tucetona laticostata (small dog cockle) and abundant Tawera subsulcata. Psychrochlamys delicatula is present, however in lower numbers than in the underlying coquina members (Anderson-Scott, 2017). The uppermost one to three metres is a wellcemented, solution-pitted cap dominated by bioclast supported Tawera subsulcata. Rodley (1961) identified occasional greywacke pebbles but notes that they are not conspicuous. The overall thickness of Limestone C is 6 to 15 m (Rodley, 1961; Anderson-Scott, 2017). 


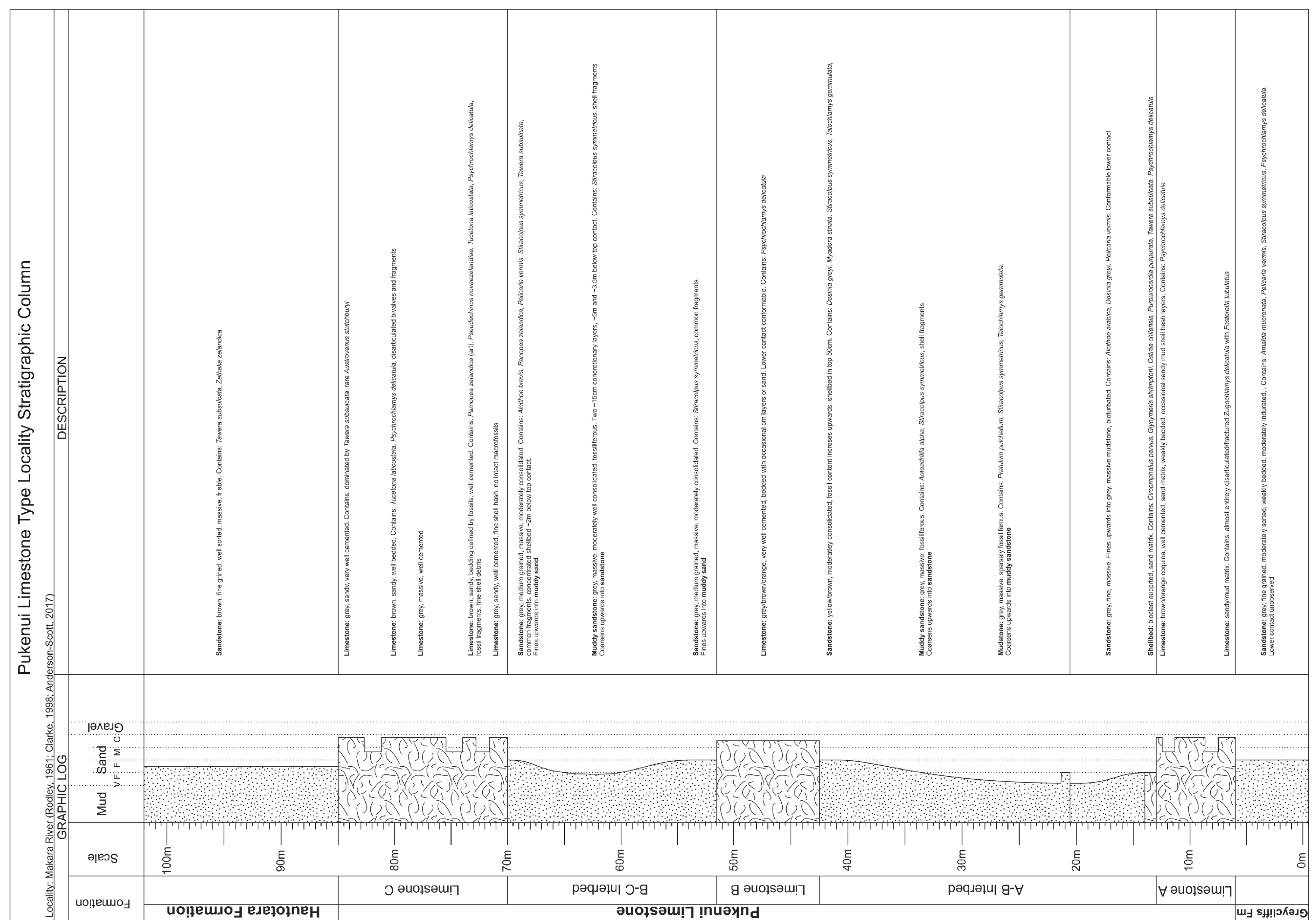

Figure 3.2: Stratigraphic column for the Pukenui Limestone type section. Data from the type locality, retrieved from Rodley (1961), Clarke (1998), and Anderson-Scott (2017) 


\subsubsection{Lower Contact}

The formal contacts of the Pukenui Limestone (Vella \& Briggs, 1971) differ to those described in in Nowland (2011). Both the lower and upper contacts were identified by geologists who defined contacts in a different sense. Below is the contact used by other researchers, followed by the definition used throughout the course of this study.

Vella and Briggs (1971) described the lower contact between the Pukenui Limestone and underlying Greycliffs Formation as sharp and wavy, separating underlying bluegrey sandy mudstone of the Greycliffs from the overlying discontinuous hard blue-grey basal sandstone of the Pukenui Limestone. However, the location of the lower contact based on Vella and Briggs (1971) description has not been used in more recent times as the rocks above and below the contact are often indistinguishable and difficult to identify in the field (Atkins, 1995; Nowland, 2011; Anderson-Scott, 2017). Paul Vella was known for separating units using complete cyclothems rather than standard field practices that are in use today. More recent studies make use of lithology and macrofossil assemblages to distinguish units and the contacts between them. Following previous workers (e.g. Atkins, 1995; Nowland, 2011), an emended definition for the formation at its type locality places the base at a conspicuous lithological and paleontological change marked by an increase in the abundance of Psychrochlamys delicatula from sparse to densely packed over a stratigraphic thickness of 1-2 m.

Nowland (2011) placed the base of the Pukenui Limestone where the abundance of Psychrochlamys delicatula increases from a sparse to a dense bed of fossils, forming an obvious exposure on weathered outcrops. The concentration of Psychrochlamys delicatula is located several metres above the formal base, however, due to the ambiguous definition provided by Vella and Briggs (1971) the actual thickness is uncertain. The informal definition used by Atkins (1995) and Nowland (2011) is firmly based on observable lithostratigraphic and macrofaunal changes. This is essential for any fieldwork, particularly mapping, as it is easily recognised. The dense bed of scallops represents a strong influx of cold-water species, which is in agreement with when the Pukenui Limestone would have undergone deposition.

In other areas, the Psychrochlamys delicatula base is replaced with a dense bed of other species of molluscs. At least two other species have been observed densely populating 
the base of the Pukenui Limestone. The author has observed Austrovenus stutchburyi (New Zealand cockle) as the main species in the base of Limestone A on the hill east of Cannock Road. Ostrea chilensis (dredge oyster) has also been observed and photographed (Tom Womack, personal communication, 2019) forming a dense bed where Psychrochlamys delicatula would be expected (location).

\subsubsection{Upper Contact}

The formal top contact of the Pukenui Limestone has suffered from a similar problem as the lower contact. Vella and Briggs' (1971) formal contact is well below what is commonly used. This is due again to the cyclothem method Vella and Briggs (1971) used. Because of this, the entire Limestone $\mathrm{C}$ was not included in Vella and Briggs' (1971) publication but was incorrectly included in Collen and Vella (1984).

The modern definition includes the Limestone $\mathrm{C}$ within the Pukenui Limestone, placing the contact between this hard coquina cap and the overlying friable sandstone. This is detailed further in section 3.3.3.

\subsubsection{Distribution and Thickness}

The Pukenui Limestone outcrops over an area approximately $80 \mathrm{~km}$ long and $6 \mathrm{~km}$ wide from the south coast of the North Island near Palliser Bay to north of Mauriceville (Beu, 1995; Dobbie, 1982). At the type section it is $73 \mathrm{~m}$ thick. Further to the north the thickness generally increases and the number of limestones decreases, so that near the northern extent the Pukenui Limestone is a single 80-90 m thick basal limestone bed (Beu, 1995). The coquina beds are prominent ridge formers (Vella \& Briggs, 1971) and form cuestas along the eastern side of the Wairarapa Valley (Beu, 1995).

\subsubsection{Paleontology, Age, and Environment of Deposition}

As with other characteristics, the paleontology of the Pukenui Limestone varies between members. Each of the coquina members typically contains similar faunal assemblages, while each of the interbeds share similar assemblages, indicating repeating depositional environments. 
The members of the Pukenui Limestone represent a repeated change in depositional environment as a result of glacio-eustatic sea-level change. As detailed below, previous interpretations have inferred that the three coquina beds and two sandy interbeds are deposited in upper shoreface and inner shelf environments respectively. Each of the coquina members was deposited during a period of low sea level while the interbeds were deposited during periods of high sea level (Nowland, 2011) On top of the glacioeustatic signal, the facies within the Pukenui Limestone represent an overall shallowing due to tectonic uplift and ongoing sedimentation (Nicol et al., 2002; Nowland, 2011).

Rodley (1961) interpreted the fauna within each coquina member as representing a shallowing, the mean depth being $\sim 20 \mathrm{~m}$. A similar water depth was also noted by Anderson-Scott (2017). The interbeds are interpreted by Rodley (1961) as being deposited below active wave base, and undisturbed by currents, in 30 to $45 \mathrm{~m}$ of water.

The faunal assemblage found within the Pukenui Limestone contains several species that are more useful and important for paleoenvironmental analysis than the majority of others. Psychrochlamys delicatula is a subantarctic species whose main environmental control is low temperature, with a preference for sediment-free conditions. They are currently found in abundance around the Subantarctic Islands and the Otago Peninsula of southern New Zealand at a range of depths (Orpin et al., 1998). Due to their preference for cold water, Psychrochlamys delicatula has been used as an indicator of Plio-Pleistocene glaciations as far north as Hawke Bay (Atkins, 1995). Multiple authors have interpreted the presence of Psychrochlamys delicatula differently (Atkins, 1995; Gammon, 1997; Orpin et al., 1998). Their increase in abundance at the base of the Pukenui Limestone was interpreted by Atkins (1995) as an influx of cold water into the Ruataniwha Strait. Their presence in community beds as disarticulated, randomly orientated, and barnacle encrusted is an indication that they were substantially reworked by storm action above the storm wave base (Atkins, 1995). Due to modern observations of Psychrochlamys delicatula, Gammon (1997) interpreted the base of the Pukenui Limestone as having been deposited in deep water near $300 \mathrm{~m}$ water depth.

The barnacle species Fosterella tubulatus is commonly attached to macrofauna throughout the coquina members of the Pukenui Limestone, most commonly attached to Psychrochlamys delicatula in Limestone A. Atkins (1995) used the presence of 
barnacles on all sides of macrofossils in Limestone A to infer that they must have been deposited near storm wave base.

Species such as Tawera subsulcata are dominant in the top $\sim 1 \mathrm{~m}$ of Limestone C, and Panopea sp. are commonly found in life position in the interbeds, however, both species are found in other members. Previous studies note that Austrovenus stutchburyi and Limnoperna huttoni (estuarine mussel), both estuarine species, have been identified in the Pukenui Limestone (Beu \& Maxwell, 1990; Nowland, 2011).

The Pukenui Limestone was deposited during the early- to mid-Nukumaruan, however there is a lack of age constraining material from which to provide exact dates (Vella \& Briggs, 1971; Beu, 1995; Clarke, 1998; Rampton, 1997; Gammon, 1997; Nicol et al., 2002; Nowland, 2011). Gephyrocapsa sinuosa (calcareous nannofossil) in the A-B Interbed restricts that particular horizon to no older than 1.80 Ma (Edwards, 1987; Nowland, 2011). The base of the Olduvai Subchron has been identified in the Greycliffs Formation (Nowland, 2011) making the base of the Pukenui Limestone younger than $1.942 \mathrm{Ma}$ (Naish et al., 1998).

Deposition was interpreted by Nowland (2011) to have occurred over the course of three $40 \mathrm{kyr}$ glacio-eustatic sea-level cycles. Using 1.80 Ma for the A-B Interbed, he gave a time range of $1.86-1.73 \mathrm{Ma}$ for the Pukenui Limestone.

The foraminifera content of the Pukenui Limestone is typically benthic species, most commonly recovered from the interbeds. Some planktonic species are also recorded in the interbeds (Clarke, 1998). The A-B Interbed contains species such as. Astrononion novozelandicum, Bolivina parri, Bulimina aculeate, Cassidulina laevigata, Elphidium charlottensis, Evolvocassidulina orientalis, and Nonionellina flemingi (Clarke, 1998). The B-C Interbed contains dominantly Elphidium charlottensis, Nonionellina flemingi and Quinqueloculina spp., which increase in abundance markedly up section (Clarke, 1998).

\subsection{Hautotara Formation}

The name Hautotara has been used previously for sediments in the Manawatu Gorge, which were believed to correlate with sediments at Hautotara (Hector, 1884). Collen 
and Vella (1984) used the name for sediments along Huangarua River downstream of Hautotara Bridge.

\subsubsection{Type Section Location}

Collen and Vella (1984) describe a section extending along the eastern bank of the Huangarua River for 400 m downstream of the junction between the Ruakokoputuna and Makara Rivers as the type section for the Hautotara Formation. Collen and Vella (1984) supplemented their type section with data from Rodley (1961) and Vella (1963), who had previously described the section. The type section described by Collen and Vella (1984) accepts the "highest cemented coquina bed as representing the top of the underlying Pukenui Limestone", initially used for mapping convenience. The coquina bed they refer to is actually Limestone F of Rodley (1961). As this does not align with modern studies, the type section outcrop only partially covers the current definition of the unit. Additionally, the construction of Hautotara Bridge has removed part of the exposure, and earthworks to protect the eastern side of the river has left the remainder of the type section overgrown.

Several other reference sections for the Hautotara Formation have been proposed (Rataul, 1988; Gammon, 1995) however the section proposed by Nowland (2011) is believed to be the best option for this study. This section is located between the Ruawaka and Huangarua Rivers (Fig. 1.1), presenting a near continuous 71 m outcrop section, representing a wide range of facies, and including both the lower and upper contacts. These features are not found together in any other observed outcrop of the Hautotara Formation, making this the best exposure known.

\subsubsection{Generalised Hautotara Formation Description}

The Ruawaka Section measured by Nowland (2011) is considered to be the most complete and current description of the Hautotara Formation. The section between the original Pukenui Limestone and Hautotara Formation type sections not accounted for in any formal publication (Vella \& Briggs, 1971; Collen \& Vella, 1984) is included in this description. The following description is adapted mostly from the Ruawaka Section of Nowland (2011). Additional notes are taken from Section 5 of Gammon (1995) and 
supplemented with the original material from Rodley (1961), and Collen and Vella (1984).

At its simplest, the Hautotara Formation is made up of three coquina members interbedded with silts, sandstones, and conglomerates (Rodley, 1961, using the modern definition of the contacts; Nowland, 2011). Individual beds exhibit a large amount of lateral variation (Gammon, 1995). Obvious lateral changes in facies are observed when comparing several of the measured sections compiled for this description. Of note is the lack of multiple coquina beds in Nowland's (2011) Ruawaka Section, which are evident in Rodley's (1961) descriptions from the Ruakokoputuna and Makara Rivers. Only the lowermost coquina bed of Rodley (1961) is identified in Nowland's (2011) Ruawaka Section. The lateral facies change is explained in Chapter 6 and is not considered a problem as the Ruawaka Section of Nowland (2011) shows the relative facies changes for the majority of the Hautotara Formation. Despite not appearing directly identical to other sections described by previous authors, the Ruawaka Section (Nowland, 2011) and Makara River section (Rodley, 1961) remain the most complete and useful for describing the Hautotara Formation at the southern end of the Nga-Waka-A-Kupe Range, when supplemented with data from other sections in the area.

Nowland's (2011) Ruawaka Section consists of a repeated sequence of sandstones, shellbeds, and gravel shellbeds. Nowland (2011) separated the sandstones and shellbeds of the Hautotara Formation at the Ruawaka Section into a variety of different facies for the purpose of determining sea-level cycles. The description provided here does not require that level of detail, and only the gross lithology and faunal content is described (Fig. 3.3).

Where the Hautotara Formation conformably overlies the Pukenui Limestone the lowermost member is a fine, friable sandstone (Rodley, 1961; Nowland, 2011). The only macrofossil species consistent between sections is Zethalia zelandica. Lenses of $<1 \mathrm{~cm}$ clasts are present in the upper $3 \mathrm{~m}$ of the member. This sandstone ranges from 7.5 m to 15 m thick (Rodley, 1961; Nowland, 2011).

The only coquina recorded at the Ruawaka Section (Fig. 3.3, $16.95-19.5 \mathrm{~m}$ ) by Nowland (2011) is here inferred to be equivalent to Limestone D of Rodley (1961). It is made up of well-cemented shell fragments, whole shells, and occasional 10-60 mm 
indurated sandstone pebbles (Rodley, 1961; Nowland, 2011). The faunal assemblage is dominated by Tawera subsulcata, with minor occurrences of Purpurocardia purpurata (clam), Myadora striata (clam), and Zethalia zelandica. Thickness ranges from $4.5 \mathrm{~m}$ to 2.5 m thick (Rodley, 1961; Nowland, 2011).

Overlying the lowermost coquina is a 9 to $14.5 \mathrm{~m}$ section of sandstone (Rodley, 1961; Nowland, 2011). This sandstone is brown, fine-grained, well-sorted, and sparsely fossiliferous. Rare Panopea zelandica and Amalda mucronata (olive shell) occur in the sandier sections. Macrofauna density increases to form occasional shellbeds, dominated by the estuarine species Austrovenus stutchburyi and Limnoperna huttoni. This sandstone is comparable to the sandstones overlying Limestone D described by Rodley (1961).

Above the sandstone layer at Nowland's (2011) Ruawaka Section (above $35 \mathrm{~m}$ ) the exposure is difficult to compare with Rodley's (1961) section at Makara River. Nowland (2011) describes a consistent repetition of gravel shellbeds and sandstones, usually with one or more shellbeds interbedded within the sandstones. This can be seen in Figure 3.3. Each repetition is usually between one and five metres thick, with the thickest being $13 \mathrm{~m}$.

The shellbeds of each section were split into separate facies by Nowland (2011). Four facies were recorded in the Ruawaka Section: $\mathrm{SB}_{1}$ (limestone), $\mathrm{SB}_{\mathrm{al}}$ (AustrovenusLimnoperna dominated shellbed), $\mathrm{SB}_{\mathrm{t}}$ (Tawera dominated shellbed), and $\mathrm{SB}_{\mathrm{z}}$ (Zethalia dominated shellbed). They share similar matrixes and differ in their faunal content. $\mathrm{SB}_{1}$ is a well-cemented brown coquina, comprised almost entirely of Tawera subsulcata, and with occasional $\sim 5 \mathrm{~cm}$ indurated sandstone clasts (Nowland, 2011). The most obvious species in $\mathrm{SB}_{\mathrm{al}}$ are the estuarine species Austrovenus stutchburyi and Limnoperna huttoni (Nowland, 2011). $\mathrm{SB}_{\mathrm{t}}$ is a moderately cemented shellbed of Tawera subsulcata in a brown sandy matrix (Nowland, 2011). The $\mathrm{SB}_{\mathrm{Z}}$ (Zethalia dominated shellbed) is dominantly Zethalia zelandica (>85\%), with minor assemblages of Tawera subsulcata. The matrix is always sandstone, usually with indurated sandstone clasts.

Above the main coquina in the section, the dominant shellbed is $\mathrm{SB}_{\mathrm{al}}$. Above the second repetition of lithologies, the shellbeds are dominated by $\mathrm{SB}_{\mathrm{t}}$ facies, and one $\mathrm{SB}_{\mathrm{z}}$ occurs in the last package near the top of the Hautotara Formation. 
The gravel shellbeds and shelly conglomerates are grey to brown conglomerates, clast supported and moderately cemented (Nowland, 2011). Clasts are dominantly subrounded to well-rounded greywacke, up to $11 \mathrm{~cm}$, and generally fine upwards. The matrix is sandy and increasingly fossiliferous with increasing height. Macrofauna are often fractured, but identifiable ones are predominantly nearshore species. Bivalves include Austrovenus stutchburyi, Tawera subsulcata, Glycymeris shrimptoni, and Ostrea chilensis. Gastropods include Zethalia zelandica and Antisolarium egenum (small wheel shell). The gravel shellbeds are considered the base of each repetition due to their inference as being deposited at sequence boundaries (Nowland, 2011). 


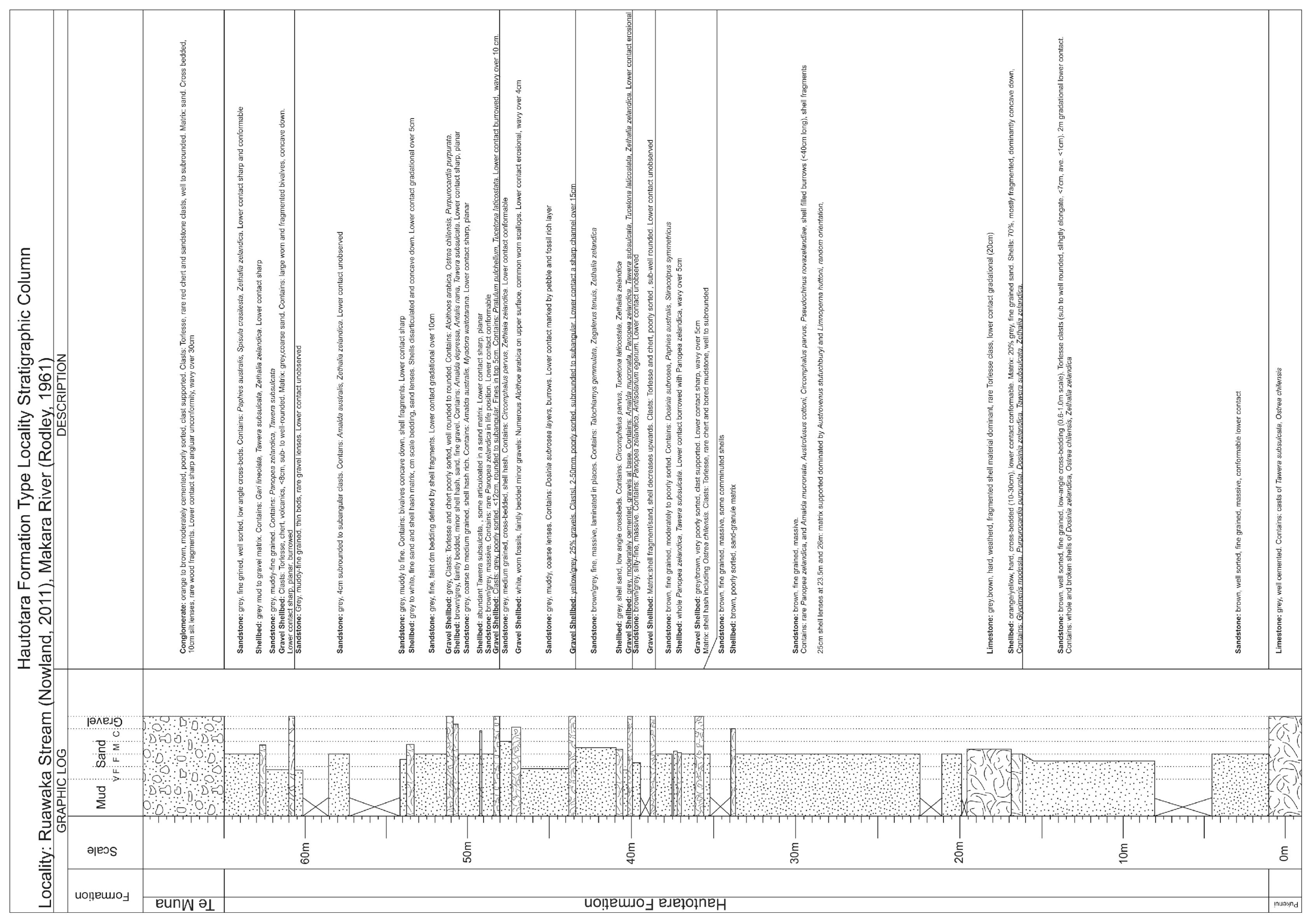

Figure 3.3: Stratigraphic column for the Hautotara Formation type section. Data from the type locality, retrieved from Rodley (1961) and Nowland (2011) 
Chapter 3 - Previous Stratigraphy 


\subsubsection{Lower contact}

Collen and Vella (1984) described the lower contact of the Hautotara Formation at only one location, on the eastern bank of the Huangarua River $1 \mathrm{~km}$ south of Te Muna Station (Fig. 1.1). "Unconsolidated gritty calcareous sandstone rests on a solution pitted surface of hard Pukenui Limestone" (Collen \& Vella, 1984). The Pukenui Limestone they present underlying the 'contact' is not the same as that presented in the type section of Vella and Briggs (1971), nor is it the same as that used in other studies (Rodley, 1961). Their definition of the contact includes "highest cemented coquina bed as representing the top of the underlying Pukenui Limestone" (Collen \& Vella, 1984). Rodley (1961) identified seven coquina beds labelled A through F (Fig. 3.1). Despite Limestones D through F not being included as part of the Pukenui Limestone by Vella and Briggs (1971), Collen and Vella (1984) placed the lower contact of the Hautotara Formation at the top of the F Limestone. Limestone F (Rodley, 1961), exposed only at the intersection of the Makara and Ruakokoputuna Rivers, is similar in appearance to Limestone C (Rodley, 1961). Additionally, the stratigraphic position of Rodley's (1961) Limestone $\mathrm{F}$ is uncertain. These reasons may explain why it was used by Collen and Vella (1984) as the base of the Hautotara Formation, leading to a significant stratigraphic section unaccounted for in any formal publication until Gammon (1995), as shown in Figure 3.1.

Gammon (1995) proposed the top of the Limestone C as the contact between the Hautotara Formation and the Pukenui Limestone. Nowland (2011) used this contact, as does this study. The top of the Limestone $\mathrm{C}$ is known to be a coarse, calcareous, sandy bed, well cemented, dominated by Tawera subsulcata casts. This "Tawera cap" forms prominent beds obvious in many streams in the field area, often forming "boat-ramps" intersecting the stream. Unconformably overlying the Limestone $\mathrm{C}$ is an extremely friable, well-sorted, medium-fine sandstone of the Hautotara Formation, labelled as Zethalia sandstone (Gammon, 1995). This contact likely represents a short hiatus (Nowland, 2011). 


\subsubsection{Top Contact and Te Muna Formation}

The contact between the Hautotara and Te Muna Formations is a slight angular unconformity which is deeply channelled (Collen \& Vella, 1984). Lamb and Vella (1987) described the contact at an area 5km north of the type area, interpreting the Te Muna Formation as conformably overlying the Hautotara Formation. They also describe higher units of the Te Muna Formation as unconformably onlapping onto progressively older units further to the east and west, including at the northern end of the Nga-WakaA-Kupe Range. At its thickest (in the Huangarua Syncline), the Te Muna Formation is $366 \mathrm{~m}$ of terrestrial conglomerate interspersed with siltstone and claystone members. It contains fossil trees in life position and rare decalcified freshwater mussels (Collen \& Vella, 1984).

\subsubsection{Distribution and Thickness}

In the field area, exposures of Hautotara Formation can mostly be found on the western flank of the Windy Peak Anticline. Outcrops extend along the range and around the northern extent of the anticline, following the eastern limb of the Ngarara Syncline to the south (Fig 1.1).

Using their definitions of the boundaries, Collen and Vella (1984) determined the Hautotara Formation was $40 \mathrm{~m}$ thick. As the modern interpretation of the lower contact has changed, the thickness in the region of the reference section is greater than the published value, closer to $70 \mathrm{~m}$. To the north near the intersection between Longbush and Hinakura Roads, the unit thins to less than $5 \mathrm{~m}$, and in places the Te Muna Formation directly overlies the Pukenui Limestone (Collen \& Vella, 1984).

Seismic reflection profiling carried out by Cape et al. (1990) shows the Hautotara Formation thickens from $35 \mathrm{~m}$ at the type area to over $100 \mathrm{~m}$ northwest of the Huangarua Syncline.

\subsubsection{Paleontology, Age, and Environment of Deposition}

There is a lack of age diagnostic species within the Hautotara Formation that could confidently provide dates for the lower and upper contacts (Collen \& Vella, 1984). However, evidence from the adjacent units can be used to constrain time of deposition. 
As such, the best approximation of age is late Nukumaruan to early Castlecliffian (Collen \& Vella, 1984; Nowland, 2011).

Several macrofossil species give evidence for deposition initiating within the Nukumaruan Stage. Zethalia zelandica and Tawera subsulcata, both found in situ within the Hautotara Formation, first appeared during the Nukumaruan (Beu \& Maxwell, 1990). Amalda opima (olive shell), a Nukumaruan restricted species, was identified by Nowland (2011) within a massive sandstone of the Hautotara Formation at Ruawaka. Species identified in the upper Hautotara Formation, including Limnoperna huttoni, Tawera subsulcata, and Barytellina crassidens, support the age of the upper contact as Castlecliffian (Nowland, 2011).

A range of environments from fully marine (fossil bearing mudstones, sandstones, and limestones) to terrestrial (conglomerates) are represented by the sediments and fauna within the Hautotara Formation. The majority of units within the Hautotara Formation were deposited in near-shore beach facies, either estuarine or littoral marine (Gammon, 1995; Collen \& Vella, 1984). Zethalia zelandica is a key species of the lower Hautotara Formation as it is a strong indicator of nearshore deposition, common in 3-5m of water in slightly protected sandstone beaches (Beu \& Raine, 2009). Limnoperna huttoni and Austrovenus stutchburyi, common throughout the formation, are estuarine restricted species (Beu \& Maxwell, 1990). Terrestrial deposits make up a small component of the Hautotara Formation (Gammon, 1995). These are usually in the form of lignites and conglomerates. Foraminiferal assemblages are present in the fully marine sandy facies. The upper units are dominated by benthic species, Notorotalia zealandica, Elphidium novozealandicum, Zeaflorilus parri, and Nonionellina flemingi (Collen \& Vella, 1984). Vella (1963) attributes the changes in depositional environments to glacio-eustatic sea level fluctuations. Later research (Gammon, 1995) attributes the change in environments to a complex combination of tectonics, glacio-eustacy, geography, and hydrodynamics. An apparent drop in sea level due to tectonic uplift, concomitant with sea-level cycles, has produced alternating marine-terrestrial cycles with an upwards shallowing trend (Gammon, 1995). Nowland (2011) interpreted his Ruawaka Section as incorporating seven and a half $40 \mathrm{kyr}$ Milankovitch sea-level cycles, for a total depositional period of $300 \mathrm{kyr}$. Using the $1.73 \mathrm{Ma}$ upper contact of the underlying 
Pukenui Limestone, this puts deposition as occurring between 1.73 Ma and 1.43 Ma (Nowland, 2011). 


\section{Chapter Four \\ Outcrop Stratigraphy}

\subsection{General Introduction}

The two sections that comprise this project's study area are here described in detail, down to the centimetre scale. This level of detail is required because, despite being considered stratigraphically equivalent to the Pukenui Limestone and Hautotara Formation, the new sections measured here are comprised of lithologies that differ from those at the type sections for these units, and contain a slightly different fauna. For this reason, neither of the new sections herein can be described in terms of the members that are observed in the type sections for the respective formations. Instead, the horizons (labelled HR\#\# for Hinakura Road and LR\#\# for Longbush Road) within each new section have been combined into packages (labelled Unit \#, ascending with increased stratigraphic height) based on the presence of similar characteristics and repetitions of features. Some, but not all, are interpreted as correlating with units found in the type sections (see Chapter 6 for discussion). Species included in each description are not necessarily exhaustive. Appendix 2 includes a table showing all species in each horizon.

\subsection{Stratigraphy of the Hinakura Road Measured Section}

The Hinakura Road outcrop (HR) was measured over a 700 m section of road, covering $\sim 130 \mathrm{~m}$ of stratigraphic height. See Enclosure A for the section and Figure 1.1 for its location. Figure 4.1 shows each of the stations along the outcrop.

Grid Reference: BQ34 1489.0 3017.0 to BQ34 1442.7 3048.0 


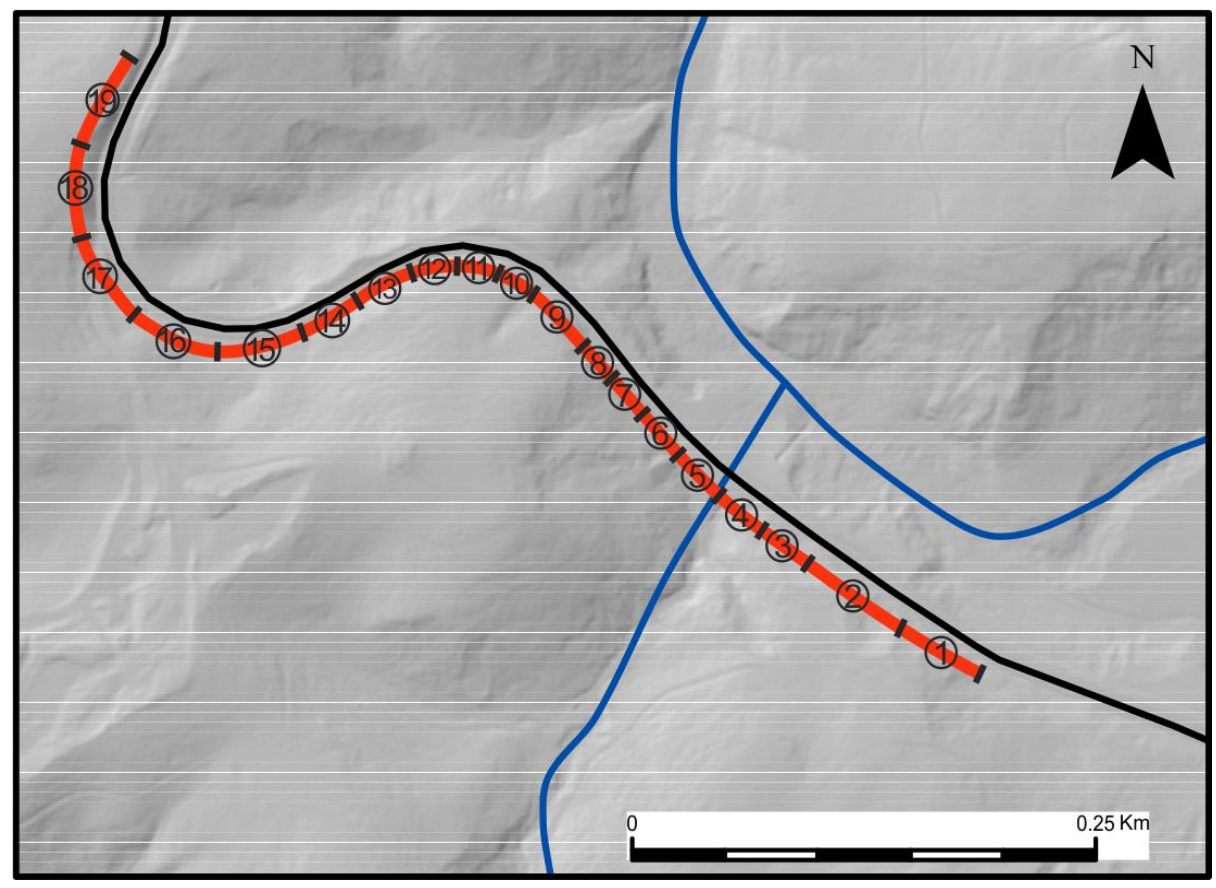

Figure 4.1: Hinakura Road measured section showing station numbers

This outcrop provides almost continuous exposure from the base of the Pukenui Limestone to well into the Te Muna Formation, including the lower contact of the Hautotara Formation. Unfortunately, it does not include the lower contact of the Te Muna Formation.

This measured section follows the work of Rampton (1997), Andrews (2001), and Nowland (2011). Rampton (1997) and Andrews (2001) produced measured sections analogous to a large portion of the Hinakura Road measured section in this study. Nowland (2011) focused on the Hautotara and Te Muna Formations, producing a section analogous to the section between $86 \mathrm{~m}$ and the top of the Hinakura Road Section.

The section along Hinakura Road is the southeastern limb of the Ngarara Syncline. Near the southeastern end of the outcrop, the beds dip $11^{\circ}$ towards the north (Fig. 4.15). Between the intersection of Cannock Road and Longbush road with Hinakura Road the same beds dip back towards the south at $\sim 2^{\circ}$.

\subsubsection{Unit 1}

The lowermost horizon identified in the Hinakura Road measured section, HR01 (Enclosure A), is a light brown, fine, friable sandstone with no observed bedding, 
sedimentary structures, or fossils (Figure 4.2, C). This unit unconformably underlies the lowermost shellbed of the section and is considered the uppermost Greycliffs

Formation. No lower contact is observed, and a minimum thickness of $4.3 \mathrm{~m}$ of this unit is observed at the Hinakura Road Section. Below this, the outcrop is slumped and overgrown.

A second outcrop, approximately $750 \mathrm{~m}$ to the east along Hinakura Road (down stratigraphic section), exposes the best example of the Greycliffs Formation found in the field area (Fig. 4.2, A). Here it is grey, muddy, massive, and macrofossil rich. The faunal content is almost entirely Stiracolpus symmetricus. The macrofossils are found in numerous densely populated clumps (Fig. 4.2, B). The lithology and faunal content of this outcrop are similar to that found in the type section for the Greycliffs Formation. The stratigraphic height of this horizon in relation to the Hinakura Road section is unknown, except to say that it is lower than HR01.

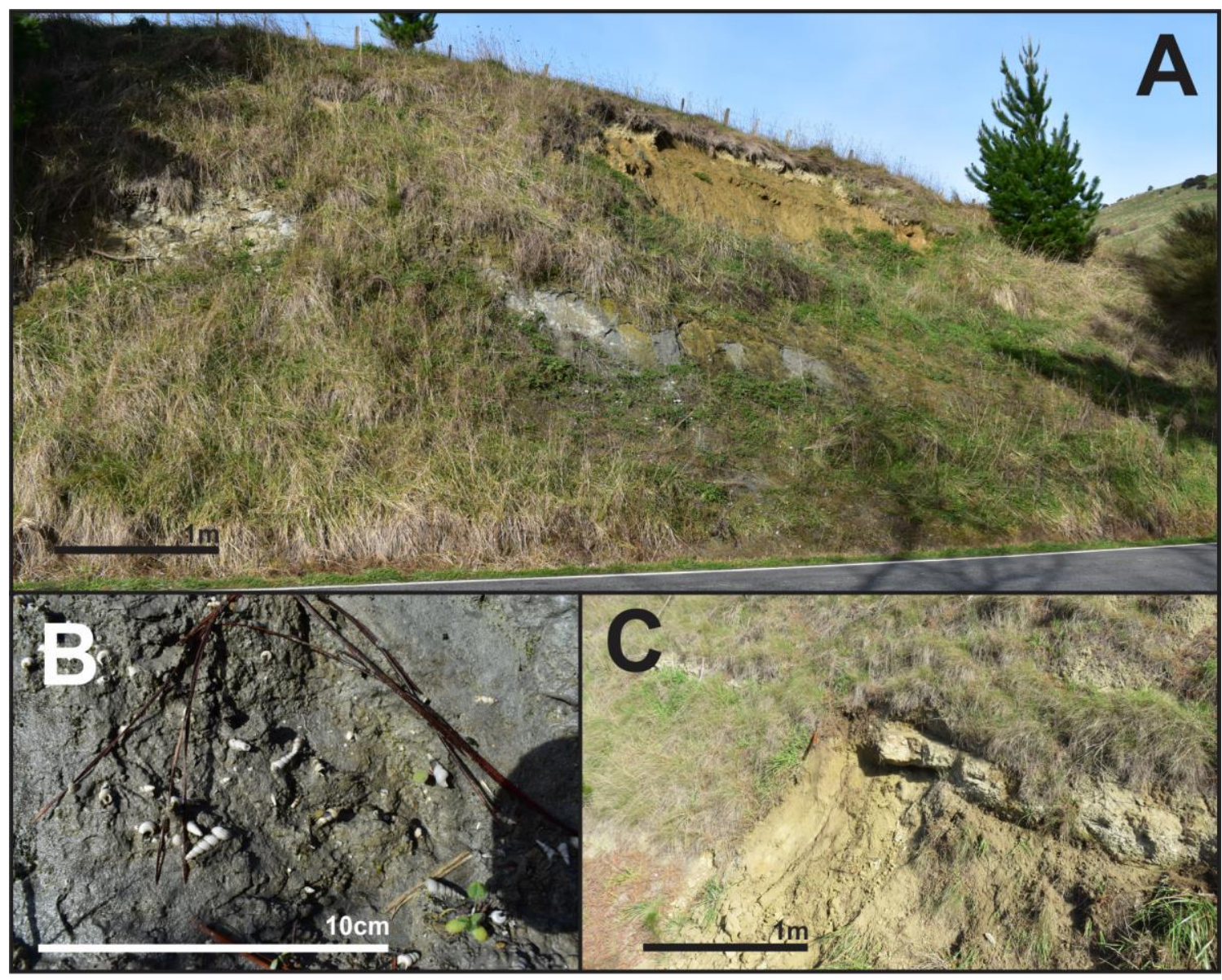


Figure 4.2: A: Greycliffs Formation 750m east of Hinakura Road measured section base. B: close-up of Stiracolpus symmetricus shells, present in common packages of high abundance. C: Friable sandstones of HR01 underlying HR02.

\subsubsection{Unit 2}

The second lithological package of the Hinakura Road outcrop is a combination of sandstone and mudstone beds bounded at the bottom and top by shellbeds HR02 and HR06 respectively, dipping to the northwest at $11^{\circ}$ (Fig. 4.3, B). Overall, the unit is sandstone dominated. This package is $6.4 \mathrm{~m}$ thick, from 4.35 to $10.75 \mathrm{~m}$ (Enclosure A).

Shellbed HR02 (Fig. 4.3, A) has a sharp lower contact. There is no indication of a stratigraphically lower hard shellbed exposed on the Hinakura Road outcrop. The pervasive weathering of units below HR02 supports the lack of a hard horizon, which would hinder slumping. As it is the lowest observed shellbed, HR02 is considered stratigraphically equivalent to the base of the Pukenui Limestone at this location, unconformably overlying the Greycliffs Formation. HR02 is $30 \mathrm{~cm}$ thick, fine to medium-grained, containing very well cemented $2 \mathrm{~mm}$ indurated sandstone clasts and shell hash. The macrofossils present are abundant, and the unit ranges from matrix to bioclast supported. Psychrochlamys delicatula is common within the shellbed, supportive of this horizon being equivalent to the lower Pukenui "A" Limestone (Fig. 4.3, A). Alcithoe arabica, Dosinia subrosea (fine Dosinia), Ostrea chilensis, Pelicaria vermis, Ruditapes largillierti (grooved carpet shell), Stiracolpus symmetricus, and Talochlamys gemmulata (fan shell) are also recorded in HR02. The macrofossils are densely packed, poorly sorted, mostly fragmented, and randomly orientated. Bivalves are occasionally articulated.

Between shellbed HR02 and HR06, the lithology ranges from fine-grained sandstone to mudstone and back to fine sandstone. HR03 is a 1.9 m moderately cemented, brown, fine-grained sandstone (Figure 4.3, C). The lower contact with HR02 is sharp and planar. Macrofossils are moderately dispersed, moderately sorted, randomly orientated, mostly unbroken. Patches of shell hash are present. Species present are Alcithoe arabica (large sea snail), Divalucina cumingii (clam), Nucula nitidula (nut clam), articulated Panopea sp., Pelicaria vermis, Stiracolpus symmetricus, Talochlamys gemmulata, and Zenatia acinaces (trough shell). 


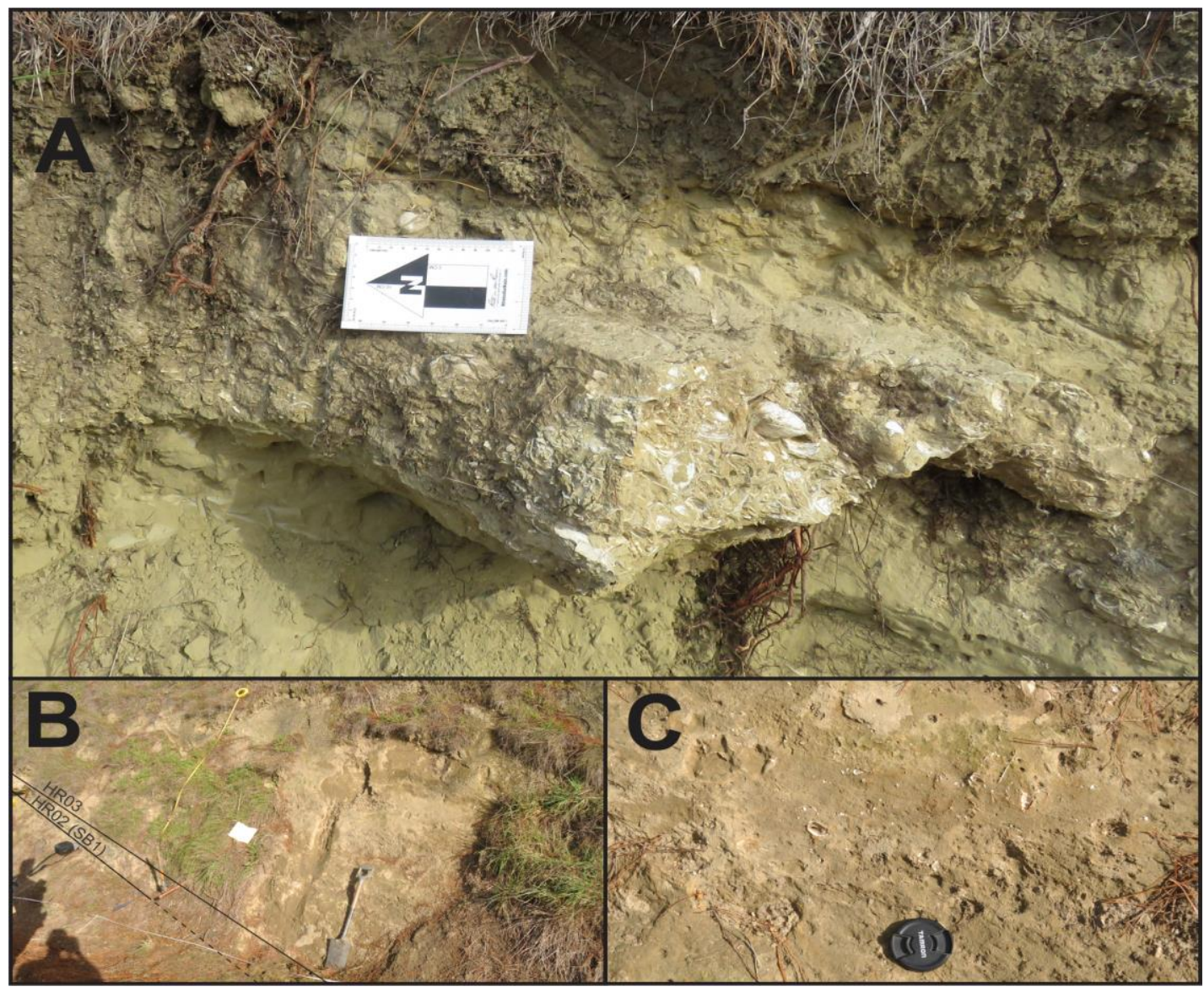

Figure 4.3 A: HR02 block protruding from outcrop (arrow direction irrelevant, scale only). B: HR02 shellbed with overlying HR03 sandstone. Spade is $\sim 1 \mathrm{~m}$ long. C: Closeup of HR03 sandstone.

HR04 consists of a massive, blue-grey $2.3 \mathrm{~m}$ thick mudstone layer. $1.65 \mathrm{~m}$ above the lower contact is a $15 \mathrm{~cm}$ brown, fine- to medium-grained, poorly sorted sandstone with a sharp lower contact. The mudstone between the sandstone layer and the upper contact exhibits platy laminations, becoming massive before the upper contact with HR05.

Above the sandstone layer, the mudstone is non-fossiliferous. Macrofauna present in the lower mudstone includes Atrina zelandica (horse muscle), Pratulum pulchellum (cockle), Scalpomactra scalpullum (small muscle), Sigapatella novaezelandiae (circular slipper limpet), and Zeacolpus vittatus (tower snail).

A $25 \mathrm{~cm}$ thick sandstone (HR05, Fig. 4.4 A \& D) overlies the mudstone of (HR04). This layer is a brown, muddy sandstone, poorly sorted, with a sharp lower contact. Fossil fragments are scattered throughout, but no whole macrofossils were observed.

HR06 exhibits similar lithologic and taphonomic characteristics to HR02 (Fig. 4.4, A \& D). Both shellbeds have similar faunal contents with the exception of only a few 
species, and with the same taphonomic attributes. The faunal assemblage includes Austrovenus stutchburyi, Dosinia subrosea, Jacquinotia edwardsii, Psychrochlamys delicatula, Ruditapes largillierti, and Tawera subsulcata. Only the tip of one Jacquinotia edwardsii claw was identified. The majority of macrofossils are fragmented, which hinders the ability to determine orientation, which is otherwise random (Fig. 4.4 C).

Above HR06 is $1 \mathrm{~m}$ of pale grey/brown coarse sandstone (HR07, Fig. 4.4 D), which fines upwards to a fine, muddy sandstone. $0.5 \mathrm{~m}$ bedding is visible. The lowermost 10 $20 \mathrm{~cm}$ contains the same fossils as HR06 and may be grading from HR06 to HR07. The following $30 \mathrm{~cm}$ contains only Amalda mucronata and Maoricolpus roseus (tower snail), which decrease in abundance rapidly upwards. Bivalve fragments are present, however are unidentifiable. 


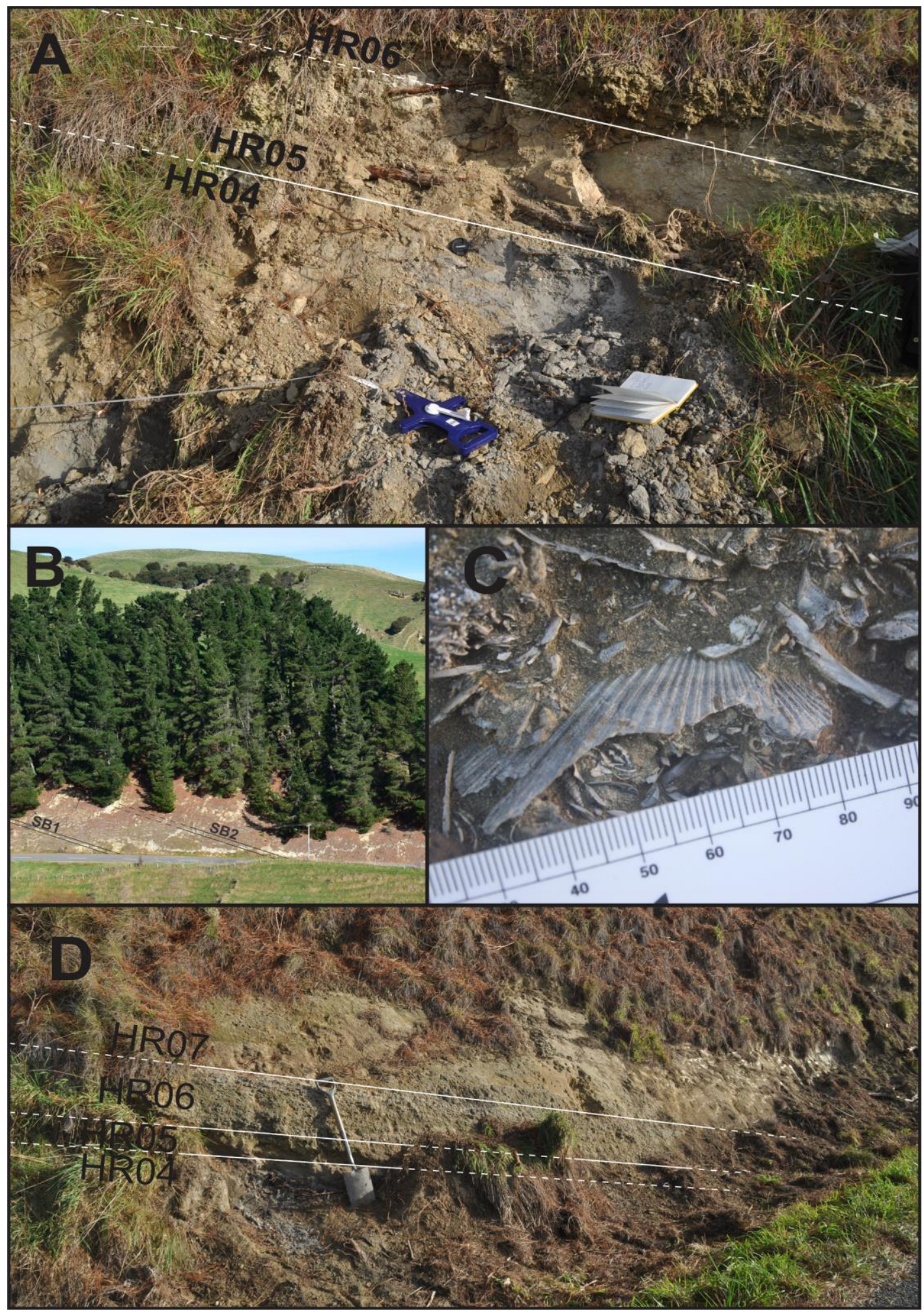

Figure 4.4: A: Freshly exposed mudstones and sandstones of HR04 and HR05 showing the weathered and overgrown nature of this section of the outcrop. B: Photograph from hill opposite outcrop, showing stratigraphic relationship between HR02 and HR06. C: Psychrochlamys delicatula from HR06 showing the state of preservation of many shells within this shellbed. This state of preservation and weathering is common. D: HR06 showing overlying sandstone (HR07), spade is $\sim 1 \mathrm{~m}$ long. 


\subsubsection{Unit 3}

Alternating mudstones and sandstones of varying thicknesses make up the $8.25 \mathrm{~m}$ of Unit 3, between 10.75 and $19 \mathrm{~m}$ on Enclosure A. This presents a shift from sandstonedominated horizons of Unit 2 to mudstone-dominated horizons. The majority of this package is mudstone and sandstone or muddy sandstone, alternating on a $10 \mathrm{~cm}$ scale. No macrofossils were observed throughout this section. The horizons of Unit 3 have been separated predominantly based on bedding. The outcrop section where Unit 3 is exposed is extremely weathered and overgrown.

The lowest horizon of Unit 3 (HR08) is a $1.15 \mathrm{~m}$ thick horizon of mudstone. This horizon is well bedded on a $10 \mathrm{~cm}$ scale, defined by alternating layers of grey mudstone and grey/brown sandy mudstone (Fig. 4.5 A). The contacts between beds are abrupt.

HR08 is overlain by a $1.1 \mathrm{~m}$ blue-grey, massive mudstone (HR09), which is in turn overlain by a $0.65 \mathrm{~m}$ sandstone (HR10). This sandstone is pale brown/grey, fine with a muddy texture, and exhibits faint decimetre scale bedding. The bedding is defined in places by orange weathering.

HR11 and HR12 are $1.4 \mathrm{~m}$ and $1.5 \mathrm{~m}$ thick respectively, both composed of $10 \mathrm{~cm}$ bedded, alternating mudstone and sandstone. HR11 is dominantly mudstone, with alternating beds of grey mudstone and brown, sandy mudstone. HR12 includes the same grey mudstone but alternated with a fine, poorly sorted sandstone.

Separating HR12 and HR14 is a $0.75 \mathrm{~m}$ brown, fine- to medium-grained muddy sandstone. HR14 is $1.75 \mathrm{~m}$ thick, with the same lithological characteristics as HR12 (Fig. 4.5 B).

Between Units 3 and 4, a stream has eroded away the outcrop, resulting in the loss of stratigraphic thickness of $26.45 \mathrm{~m}$. This is between 19 and $45.45 \mathrm{~m}$ on Enclosure A. 


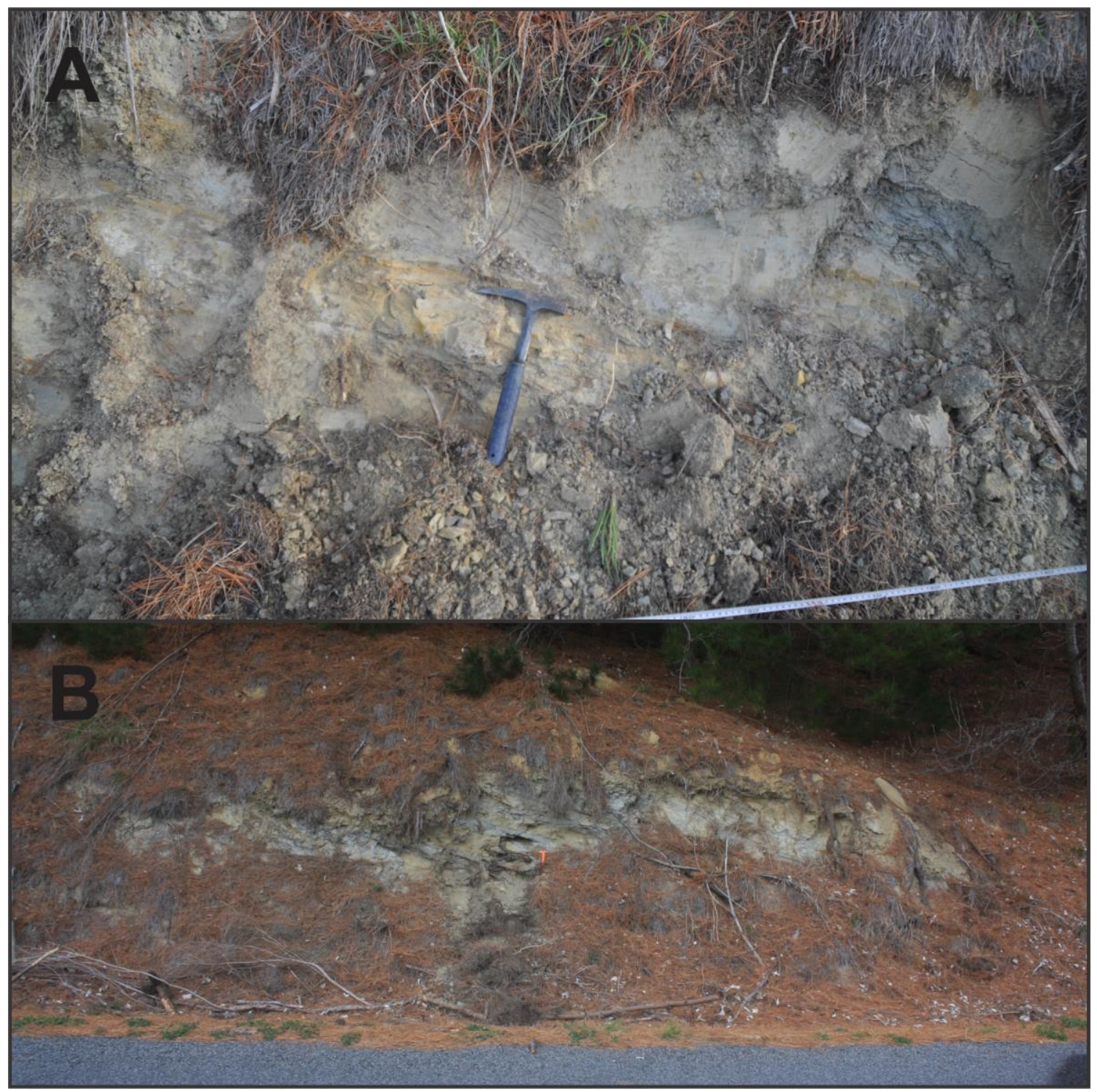

Figure 4.5: A: Interbedded mudstones and sandstones from the lower section of Unit 3. B: Interbedded mudstones and sandstones from the top of Unit 3 . Hammer in both photos is $\sim 30 \mathrm{~cm}$ long

\subsubsection{Unit 4}

This unit is $41.45 \mathrm{~m}$ thick and is almost entirely composed of muddy sandstone, from 45.45 to $86.9 \mathrm{~m}$ on Enclosure A. The majority of variation between horizons is due to differences in faunal content. The contacts between horizons of similar lithology are generally gradational. Due to the section of no exposure, the contact between Unit 3 and Unit 4 is unobservable, and therefore cannot be stratigraphically well constrained. It is placed within the section of no exposure, but no exact height is given. 
Exposure begins in Unit 4 with $1 \mathrm{~m}$ of shell rich sandstone, of which the top $0.4 \mathrm{~m}$ (HR17) is a moderately well cemented shellbed (Fig. 4.6 B). The lower two horizons (HR15 \& HR16) share similar lithological characteristics, differing in their faunal content and state of preservation (Fig. $4.6 \mathrm{~B}$ ). HR 15 is $40 \mathrm{~cm}$ thick containing Amalda mucronata, Austrovenus stutchburyi, and Limnoperna huttoni. The latter species is occasionally articulated. Important species in the middle $0.3 \mathrm{~m}$ horizon (HR16) are Panopea sp., Pelicaria vermis, Talochlamys gemmulata, Dosinia greyi (venus clam), and Tawera subsulcata. The shellbed HR17 is grey, has a muddier texture than the underlying sandstone, is well cemented, and a greater component of the fauna within is articulated compared to the underlying horizon (HR16). Species present are Antisolarium egenum, Austrovenus stutchburyi, Limnoperna huttoni, Patro undatus (oyster), and Scalpomactra scalpullum. As with HR15 below, Austrovenus stutchburyi and Limnoperna huttoni form an important component of the respective horizon (Fig. 4.6 C).

Overlying the HR17 shellbed is a 7.9 m thick grey sandstone (HR18, Fig. 4.6 A). The lithology is a poorly sorted muddy fine- to medium-grained sandstone, coarsening upwards. Laminations are observed, defined by shells, which are sparse throughout the horizon. Key species include Dosinia greyi, Panopea sp., Pelicaria vermis, Talochlamys gemmulata, and Tawera subsulcata. There is a colour change in the top two $m$ of this horizon, from a dark grey to a light brown. This colour change is observed at other outcrops in the field area, where the majority of horizons below are grey, and the majority above are brown. The colour change is covered in Section 4.4.

Upsection in HR19 cementation increases and grainsize decreases conformably from the fine-medium grained sandstone of HR18 to a well-cemented fine-grained but still mudstone horizon, $1.2 \mathrm{~m}$ thick. Shell hash becomes more prominent. Panopea sp. in life position are the most common fossil found in HR19. One example only of Calliostoma sp. (large wheel shell) was observed (Fig. 4.6 D). Other species are Alcithoe arabica and Divalucina cumingii. The overlying $1.55 \mathrm{~m}$ thick HR20 horizon appears to have the same lithology but is devoid of fauna. This may be due to the limited exposure, as fauna are sparse in the adjacent units too. However, there was also a lack of shell hash, which is more common in the adjacent units than whole macrofossils, and should have been obvious if present. 


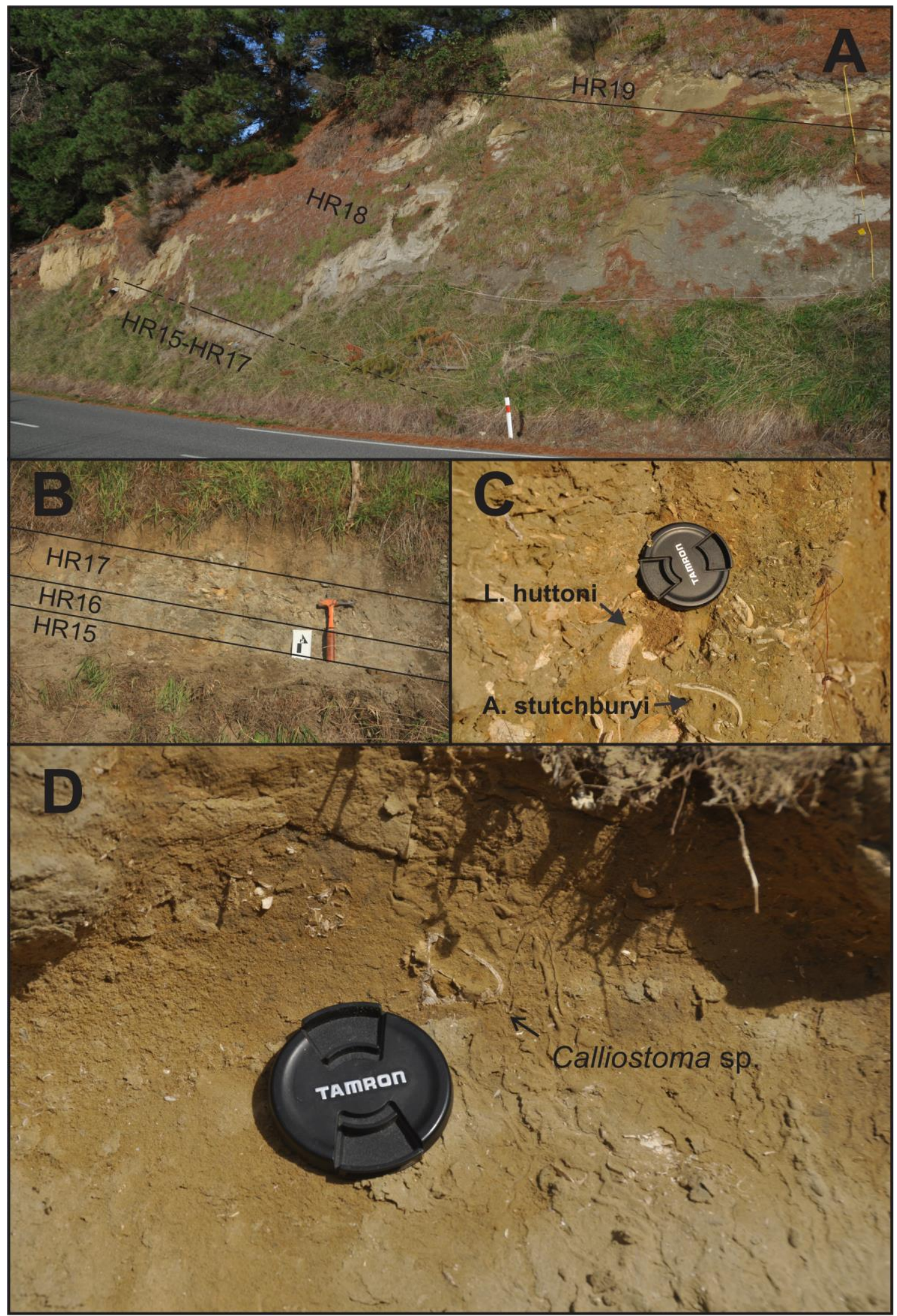

Figure 4.6 A: Outcrop showing HR15 to HR19. B: HR15, HR16, and the shellbed HR17. C: Close-up of shellbed HR17, showing the estuarine clam Austrovenus stutchburyi and estuarine mussel Limnoperna huttoni. D: Close-up of HR19, showing brown sandstone and Calliostoma sp. 
HR20 grades up from fine-grained sandstone to a fine- to medium-grained sandstone horizon with common shell hash and several identified macrofauna species (HR21). These include Dosinia greyi, Panopea sp., Pelicaria vermis, and other unidentified bivalves (Fig. 4.7 A). Panopea sp. are articulated and occasionally in life position. The $6.85 \mathrm{~m}$ thick fine- to medium-grained HR21 grades up to a $9.5 \mathrm{~m}$ thick horizon (HR22), again with similar lithological characteristics. HR22 contains rare shell hash, and no macrofauna were observed.

Where the sandstone of HR22 was well cemented, the overlying $0.5 \mathrm{~m}$ thick, mediumgrained sandstone of HR23 is friable. No fossils were observed in this horizon. Between HR23 and HR24 is a $0.25 \mathrm{~m}$ section of no exposure where the outcrop is obscured by vegetation.

Exposure continues with a $3.65 \mathrm{~m}$ macrofossil and shell hash rich horizon (HR24). Species present are abundant Antisolarium egenum (Fig. 4.7 B), Notomegabalanus sp., and Talochlamys gemmulata. Grainsize fines in the top $1.5 \mathrm{~m}$ of HR24 and the species count increases. Additional species are Aeneator imperator (Fig 4.7 C), Amalda mucronata, Bassina parva (Fig. 4.7 D), Paphies subtriangulata, Pelicaria vermis, and Zenatia acinaces.

HR25 is slightly coarser than HR24 but contains a similar faunal assemblage. Shell hash increases upwards. Important species are Amalda australis, Dosinia sp., Panopea sp. in life position (Fig.4.7 E), Pelicaria vermis, and Zenatia acinaces. 


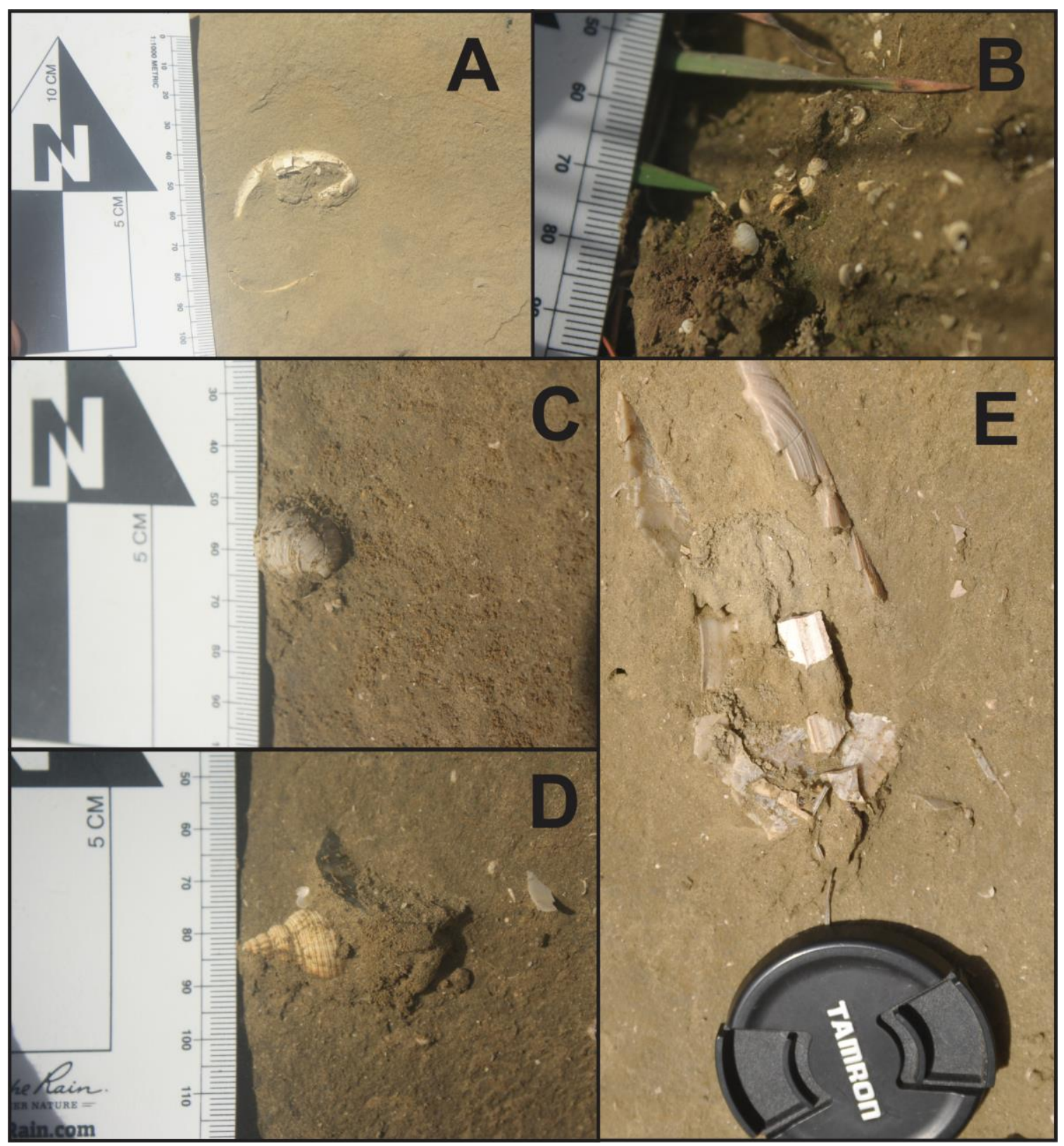

Figure 4.7 A: unidentified bivalve in HR21. B: Antisolarium egenum in HR24. C: Bassina parva in HR24. D: Aeneator imperator in HR24. E: Panopea sp. in life position in HR25. 
The top 4 m of Unit 3 (HR26) is an orange/brown coarse-grained, well-cemented shellbed dominantly composed of Tawera subsulcata (Fig.4.8 A, C, D). Because of this monotypic assemblage, this shellbed has been labelled Tawera Shellbed (TSB). Single examples of four other species were recorded: Alcithoe sp., Myadora striata (Fig. 4.8 B), Pelicaria vermis (Fig. 4.8 B), and Talochlamys gemmulata. The macrofauna within this shellbed are stained the same orange as the sandstone matrix. TSB is the stratigraphically highest well-cemented shellbed observed at this section. The lower $1 \mathrm{~m}$ includes large scale cross-bedding (Fig. $4.8 \mathrm{~B}$ ), and the lower $2 \mathrm{~m}$ includes rip-up clasts. The top $1 \mathrm{~m}$ contains $2 \mathrm{~mm}$ indurated sandstone and quartz clasts. Decimetre scale discontinuous, coarse-grained, well-cemented sandstone lenses are present in the lower $2 \mathrm{~m}$ of HR26. Rare Tawera subsulcata valves are found in the lenses. The lenses share many characteristics with the overall Tawera shellbed, however the faunal content is greatly reduced. The lower contact of this unit is abrupt. As this is the only moderately cemented, Tawera dominated shellbed observed in the section, it is inferred to be stratigraphically equivalent to the Tawera cap present in the top several metres of the Pukenui C limestone.

Figure 4.8 (following page): A: Hinakura Road section Station A offshoot. The very top of HR26 (TSB) can be seen at the top of the yellow tape, $\sim 10 \mathrm{~m}$ above the road. Author is standing at the boundary between HR25 and HR26. B: Photograph of Pelicaria vermis and Myadora striata in HR26 (TSB). These were the only examples of these species found at this horizon. C: part of HR26, showing cross-bedding (indicated by faint dotted lines). Sandstone overlying the cross-bed is base of a sandstone lens. D: Photograph of lower TSB (HR26), showing dense bed of Tawera subsulcata in a coarse matrix. 


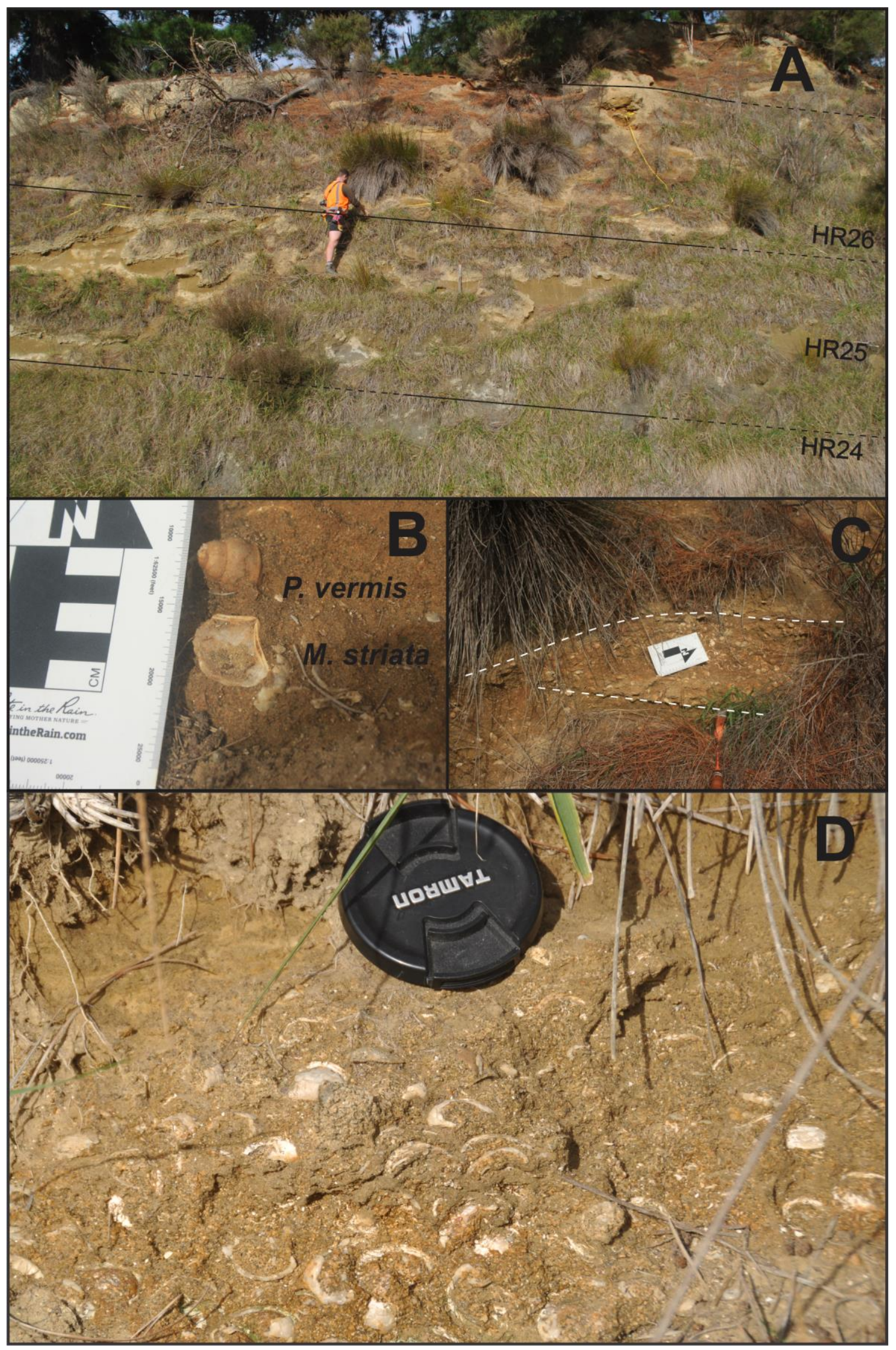




\subsubsection{Unit 5}

The lower contact of Unit 5 is placed between HR27 and the Tawera Shellbed (TSB) of HR26 (Fig. 4.9, A). The friable, shell hash dominated sandstone containing Zethalia zelandica (Fig. 4.9, B) overlying the cemented Tawera rich horizon represents a noticeable change in outcrop appearance. This is observable when comparing Figure 4.9 (B) showing HR27, to Figure 4.8 (D) showing HR26. Unit 5 is between 86.9- and $112.35 \mathrm{~m}$ on Enclosure A, a total of $25.45 \mathrm{~m}$.

The lowest horizon of Unit 5 (HR27, Fig. 4.9, B) is a brown, friable, shell hash rich, fine to medium-grained sandstone. Whole macrofauna are rare and include Austrovenus stutchburyi, Tawera subsulcata and Zethalia zelandica. This horizon marks the first appearance of Zethalia zelandica at the Hinakura Road section. Whole fossils initially appear sparse within the outcrop due to weathering, however, they are moderately common, with some areas being bioclast supported. Degree of fracturing is moderate, orientation is random, and all bivalves are disarticulated. There is a moderate degree of cementation near the lower contact with the underlying TSB (HR26). Occasional 1-4 $\mathrm{cm}$ clasts were observed in this horizon.

Between the lowermost horizon (HR27) and the upper horizons (HR28) of Unit 5 is 19 m stratigraphically of no exposure, where the outcrop is eroded and covered by vegetation. Exposure continues for 4.6 m (HR28-31) with a series of sandstone horizons with similar characteristics to HR27, the majority of which are shell rich.

HR28 is brown, medium-grained sandstone, containing common shell fragments. The sandstone is friable, however, the top $5 \mathrm{~cm}$ is cemented. A $5 \mathrm{~cm}$ long, mudstone lined burrow is present at the top of HR28 (Fig. 4.9 D). The burrow is filled with orange shell hash, lacking any sandstone or other matrices. No whole macrofossils were observed in this horizon. Overlying HR28 is a $20 \mathrm{~cm}$ thick, grey sandstone (HR29) with similar lithological characteristics, and containing Austrovenus stutchburyi, Pleuromeris sp., and Talochlamys gemmulata. Barnacle plates were also observed. The contact between HR28 and HR29 is abrupt.

A 1.25 m friable, medium- to coarse-grained poorly sorted sandstone makes up HR30. This sandstone is bioturbated, contains abundant shell hash, and has a sharp lower contact. The only identifiable species is Gari lineolata. 
The $2.45 \mathrm{~m}$ sandstone overlying HR30 is less coarse and more cemented. Whole bivalves are present, representing a greater faunal assemblage. HR31 contains Pleuromeris sp., Austrovenus stutchburyi, and Dosinia sp.. The faunal content increases in the middle $20 \mathrm{~cm}$ to from a minor shellbed.

Three horizons are found in the next $45 \mathrm{~cm}$ : two $15-20 \mathrm{~cm}$ shellbeds separated by a $15-$ $20 \mathrm{~cm}$ sandstone. The shellbeds share similar lithological characteristics but contain different species. They are orange/brown, medium-grained, poorly sorted, wellcemented sandstone with common shell hash. The lower shellbed (HR32) contains Amalda australis, Austrovenus stutchburyi, Dosinia and Dosina sp., Myadora striata, and Zethalia zelandica. Where decently exposed, the upper shellbed (HR34) is undercut. It contains Dosinia sp., Glycymeris modesta, Penion sp., Tawera subsulcata, Zemysia zelandica, and Zethalia zelandica. The condition of the macrofossils is the same in both shellbeds: the packing is loose, mostly matrix-supported, with a moderate sorting of species, a moderate to high amount are fractured, orientation is random or indeterminable, and disarticulation is dominant. The sandstone bed separating the two shellbeds (HR33) is pale brown, coarser than the shellbeds, and is well cemented. The species of macrofossils present is similar to the two adjacent shellbeds, but are sparsely packed. This horizon contains Amalda mucronata, Aeneator sp., Dosinia and Dosina sp., and Panopea sp., valves.

The uppermost horizon (HR35) is a $0.9 \mathrm{~m}$ brown sandstone. This unit is coarse and poorly sorted, except for a $10 \mathrm{~cm}$ muddy fine sandstone $30 \mathrm{~cm}$ below the upper contact. The overall unit is laminated. 1 millimetre indurated sandstone fragments are common. $10 \mathrm{~cm}$ cross-beds are present in the highest $40 \mathrm{~cm}$, with a $30^{\circ}$ angle (Fig. 4.9, E). 10 x 5 $\mathrm{cm}$ rip-up clasts composed of mudstone are found $10 \mathrm{~cm}$ above the lower contact. Macrofossils in this unit are relatively sparse compared to the underlying shellbeds, however shell hash remains abundant. Dosinia sp. and Dosina sp. valves are found concave down, and Zethalia zelandica are also present. The upper contact is obscured by vegetation. 


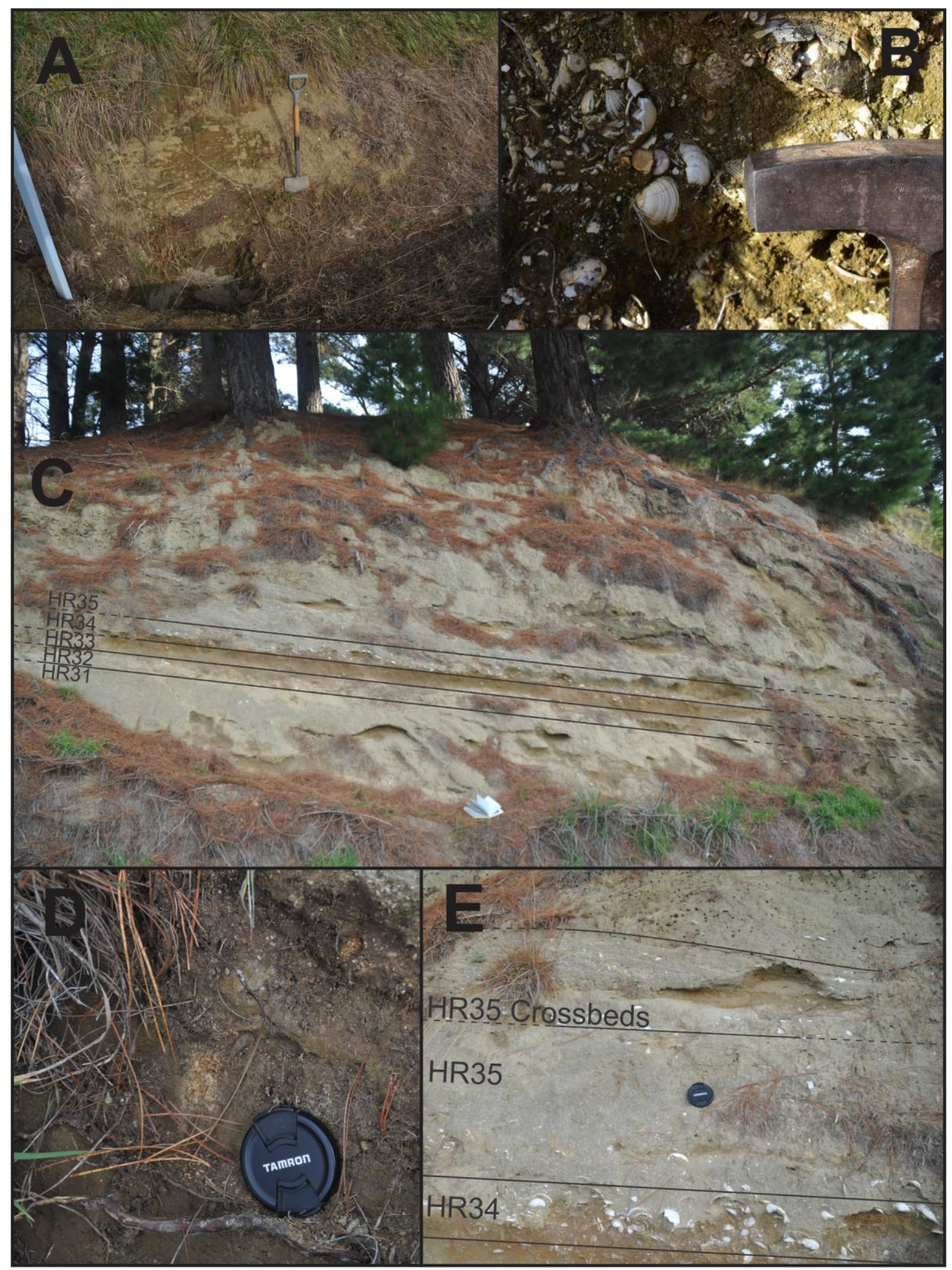

Figure 4.9: A: Unit 5/Unit 4 contact in drain sump, spade is $\sim 1 \mathrm{~m}$ long. B: Close-up of Tawera subsulcata and Zethalia zelandica at Unit 5/Unit 4 contact. C: Outcrop section of Unit 5 showing horizons HR31-HR35. Note the changes that occur between HR32, HR33, and HR34, mostly the colour change and outcrop profile. D: $\sim 5 \mathrm{~cm}$ burrow of HR28. E: Crossbedding in HR35, from far right of tile C 


\subsubsection{Unit 6}

Above HR37 of Unit 5 is a section of no exposure representing $3.1 \mathrm{~m}$ of no exposure between 112.35 and 115.45 metres on Enclosure A. The lower contact of Unit 6 lies within this section of no exposure and cannot be constrained more. Exposure continues with a 2.15-m horizon of matrix-supported conglomerate (HR36). The matrix is a finegrained yellow/brown sandstone. The clasts are indurated sandstone, $0.5-$ to $7 \mathrm{~cm}$ in size, with an average size of $2 \mathrm{~cm}$. They are rounded to subrounded. Faint imbrication indicates a flow direction to the west.

7.15-meters of no exposure separates HR36 and the conglomerates of HR37. This horizon varies between matrix and clast supported. The matrix is fine-grained, yellow/brown sandstone. The clasts are dominantly indurated sandstone with a minor component $(<1 \%)$ igneous. They are $0.5-$ to $9 \mathrm{~cm}$ with an average size of $2 \mathrm{~cm}$. Faint imbrication indicates flow to the north.

A $10 \mathrm{~cm}$ thick horizon of very poorly sorted muddy to coarse-grained sandstone (HR38) overlies the conglomerate of HR37. Clasts smaller than 3-millimetres are present. A 20 $\mathrm{cm}$ thick, laminated, pink/grey tephra (HR39) overlies the sandstone with a sharp lower contact. This tephra is equivalent to the Hinakura Road Lower tephra included in Nowland (2011). HR40 is a pale white/grey, $1 \mathrm{~m}$ thick mudstone. This horizon is clayrich, coarsening upwards to become sandy directly below the upper contact. Iron nodules are present.

HR41 encompasses $1.9 \mathrm{~m}$ of conglomerate, varying between matrix and clast supported. The matrix and clasts are the same as those found in HR37. Overlying HR42 is a $25 \mathrm{~cm}$ muddy to coarse-grained, very poorly sorted sandstone, identical to HR38. A $1.1 \mathrm{~m}$ pale white/grey, clay-rich, sandy mudstone (HR44) identical to HR40 overlies the sandstone of HR42. $15 \mathrm{~cm}$ of yellow/white tephra (HR44; equivalent the Upper Hinakura Road tephra of Nowland, 2011) and $1 \mathrm{~cm}$ of lignite overlies the mudstone before exposure continues with mudstone (HR45 and HR46) similar to HR43. Near the top of this mudstone are centimetre scale laminations.

The upper contact of HR46 is the highest exposure described at the Hinakura Road outcrop. 


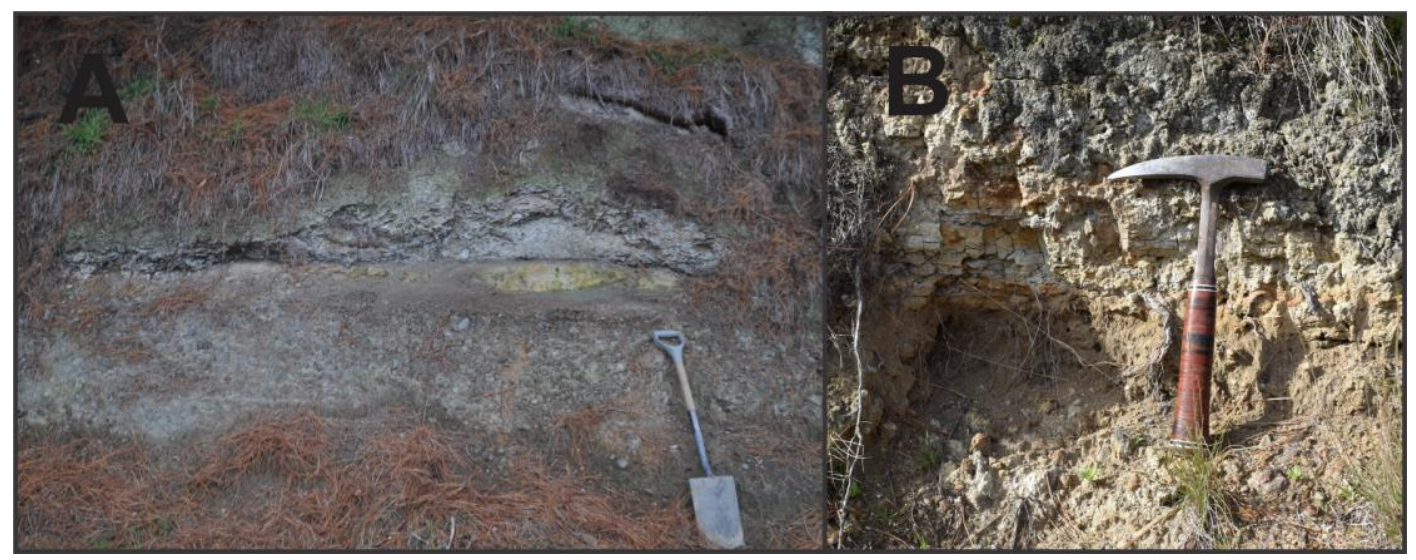

Figure 4.10: A: Lower tephra of the Hinakura Road section, amongst conglomerate of Unit 6. Spade is $\sim 1 \mathrm{~m}$ long. B: Upper tephra of the Hinakura Road section, showing vertical variations in colour and weathering. Hammer is $\sim 30 \mathrm{~cm}$ long.

\subsection{Stratigraphy of the Longbush Road Measured Section}

The Longbush Road (LR) measured section was logged over a $330 \mathrm{~m}$ section of road cutting. See Enclosure B for the section and Figure 1.1 for its location. Figure 4.11 shows the stations along the outcrop.

Grid Reference: BQ34 1420.0 3208.0 to BQ34 1450.0 3208.4

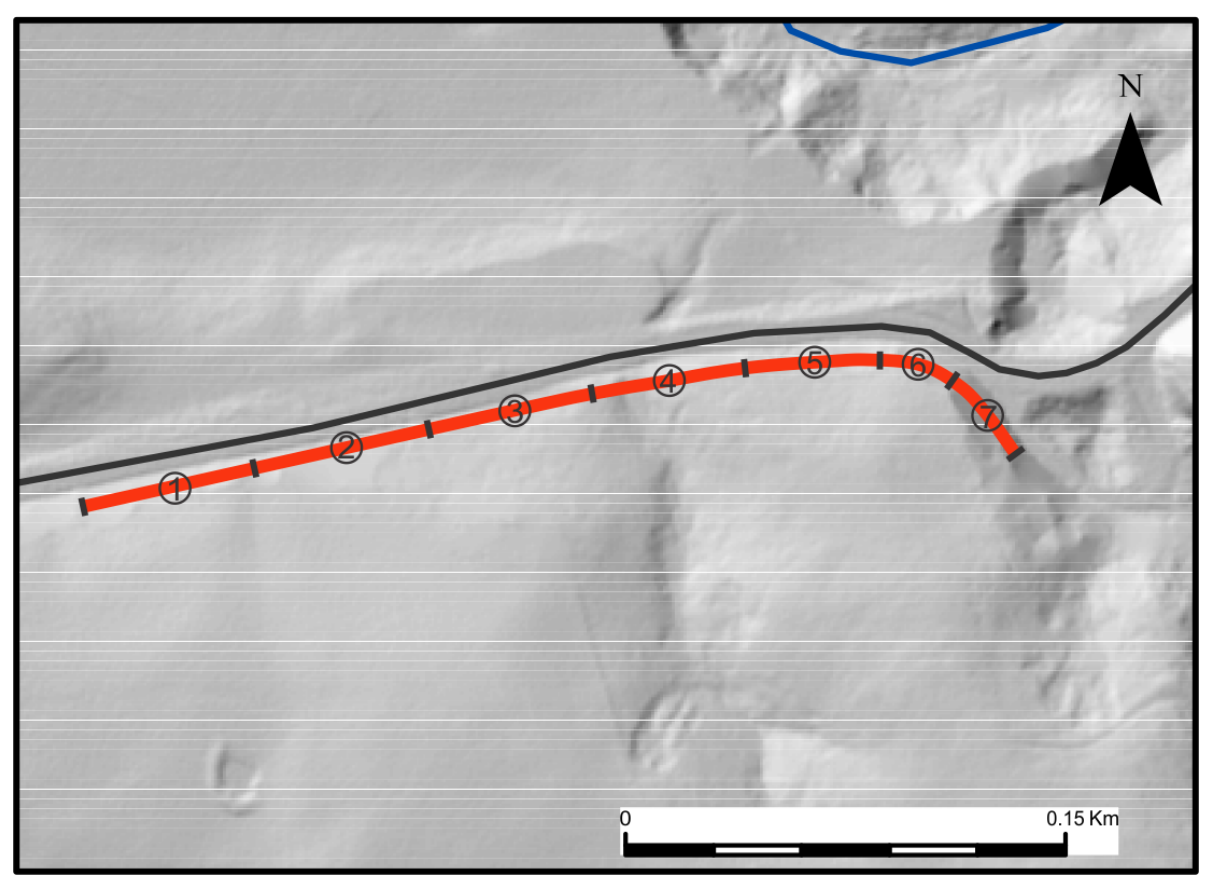

Figure 4.11: Longbush Road measured section showing station numbers 
The road cutting measured for the Longbush Road section continues for a further $\sim 700$ metres, ending on the northern side of Taylors Bridge, and it was initially intended to be described. However, the $700 \mathrm{~m}$ of material nearest to Taylors Bridge is not included. The Longbush Road outcrop was originally thought to include the entire Pukenui Limestone. Unfortunately, further investigation revealed that due to the structure of the area only a small thickness of the stratigraphy is present: $\sim 30$ metres of stratigraphy from the Te Muna Formation down to the upper Pukenui Limestone. The entire proposed section was described, however, the majority was found to be a repeated sequence. In addition, the repeated section is extremely slumped and overgrown. The repetition is due to the relationship between the changing dips and the way the road has been cut into the hillside.

The apparent dip of the outcrop along Longbush Road is approximately parallel to the road. At the southern end at the top of the hill, the dip is close to $0^{\circ}$, while at the northern end below Taylors Bridge (Fig. 1.1) it is $05^{\circ}$ to the northwest. Due to the change in dip and its similarity to the road, there is little change in stratigraphy along the outcrop. This limits the outcrop's usefulness, as it does not include the entire Pukenui Limestone.

The change in dip over the length of this outcrop represents the western limb of a northeast-trending anticline to the west of the Ngarara Syncline. This is likely to be the northern extent of the Windy Peak Anticline (Fig. 1.1), however there is a lack of structural data in the area from which to draw conclusions.

\subsubsection{Unit 1}

The lowermost unit of the Longbush Road measured section is a $10 \mathrm{~m}$ thick package of fossil-rich sandstones and shellbeds. The most obvious variation between horizons within Unit 1 is the species count and density of the faunal assemblages. Faint, discontinuous shellbeds are common throughout most horizons, however many appear to be lenses. This may be due to the weathered nature of the outcrop. Contacts between horizons are usually gradational, making this unit appear as one sandstone with beds defined by concretions and shellbeds (Fig. 4.12, A).

A grey, medium-grained, poorly sorted sandstone makes up LR01, the lowermost horizon observed at the Longbush Road section. This horizon is well cemented. A 
concretionary layer is found in the top $25 \mathrm{~cm}$, parallel to bedding. Macrofossils are sparse and poorly preserved throughout LR01. The most abundant species is Antisolarium egenum. Austrofusus sp., Panopea sp., Pelicaria vermis, and Struthiolaria sp. area also present. Zenatia acinaces were found, occasionally articulate. No regular orientation of fossils is observed and most are fractured. No lower contact was observed, giving a minimum observed thickness of $3.1 \mathrm{~m}$.

Between LR01 and LR02 is an obvious colour change from grey (LR01) to brown (LR02). This colour change is observed at multiple locations along Longbush and Hinakura Road, including both measured sections in this study. A slight increase in grainsize is recorded, and the number of macrofossil species increases. Horizontal, 15millimetre burrows are observed protruding from the outcrop at the contact between LR01 and LR02. Two concretionary layers are present at $\sim 1$ and $\sim 2$ metres above the lower contact. Alcithoe arabica, Amalda mucronata, Bassina parva, Myadora striata, Dosinia greyi, Paphies porrecta, Panopea sp., Pelicaria vermis, Talochlamys gemmulata, Tawera subsulcata, and Zenatia acinaces are recorded in LR02. The fossils are sparsely packed and randomly orientated. They are usually whole with only a small degree of fracturing but bivalves are dominantly disarticulated. This unit is three metres thick.

A $10 \mathrm{~cm}$ shellbed composed of Myadora striata and Tawera subsulcata forms the lower contact of LR03. Overlying the shellbed is $1.5 \mathrm{~m}$ of well-cemented grey sandstone. A concretionary layer is present $50 \mathrm{~cm}$ above the shellbed, which is associated with a layer of fractured Dosinia sp. shells.

LR04 contains three Tawera subsulcata rich shellbeds (Fig. 4.12, C \& D), with a minor component of other species, usually Dosinia greyi. The Tawera subsulcata display a range of articulation, which varies between each shellbed. In the lowermost shellbed, disarticulation is dominant, while in the middle shellbed articulated shells are dominant. The top shellbed contains a mixture of disarticulated and articulated shells. Shells are commonly fragmented and randomly orientated. The matrix throughout this unit and the shellbeds is a brown, medium to coarse-grained sandstone. Overall, the horizon is 3.5meters thick. 


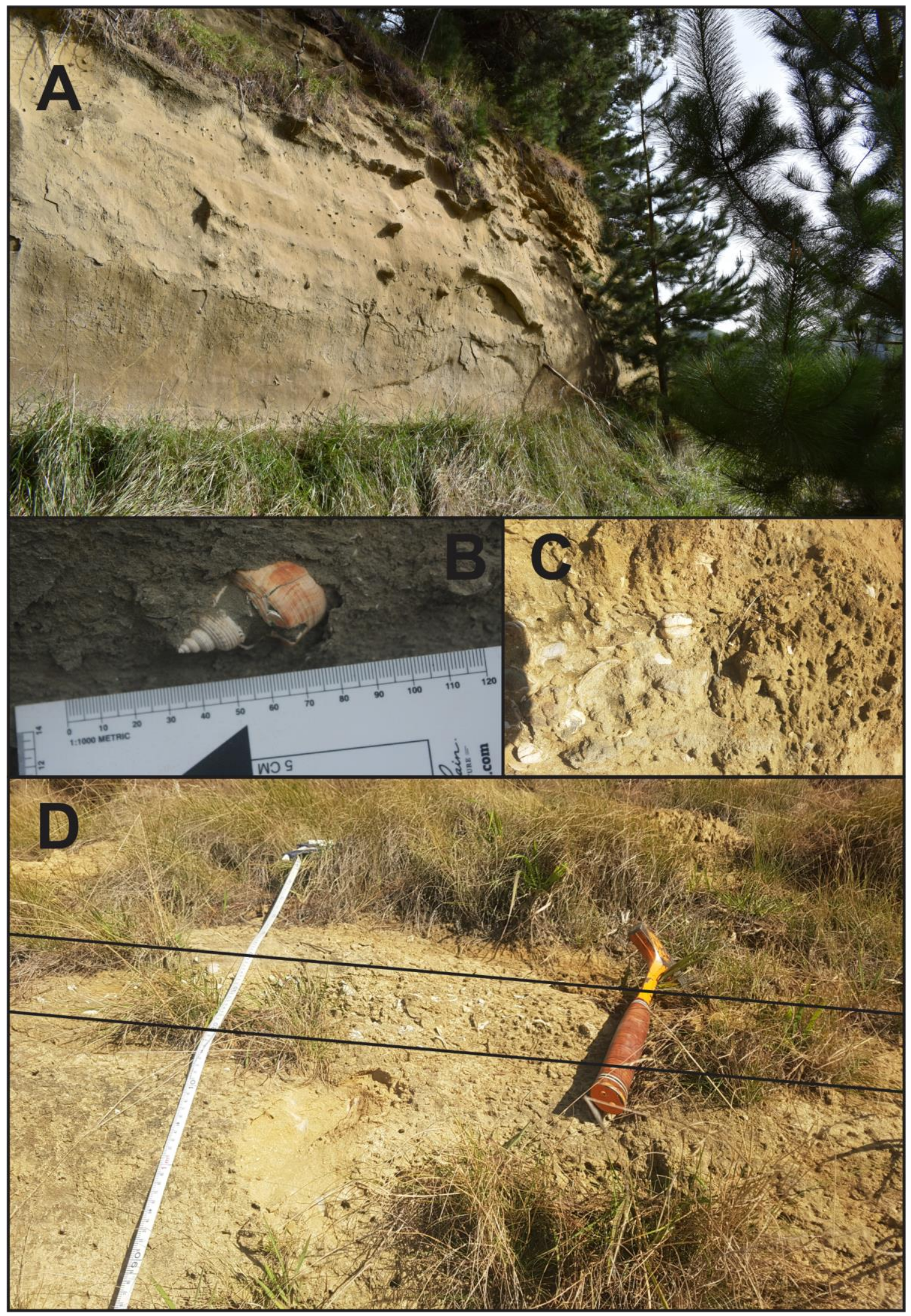

Figure 4.12 A: Concretions in LR01-LR03. B: Struthiolaria sp. in LR02. C: Close-up of a Tawera dominated shellbed from LR04. D: Tawera dominated shellbed (outlined with black lines) in LR04.2 


\subsubsection{Unit 2}

Between Unit 1 and Unit 2 is $4.5 \mathrm{~m}$ of no exposure. Here the outcrop is slumped and overgrown with vegetation.

Unit 2 is $2.7 \mathrm{~m}$ thick, composed of an $80 \mathrm{~cm}$ thick, non-fossiliferous sandstone (LR05) overlain by a $1.95 \mathrm{~m}$ thick, very fossiliferous shellbed (LR06). LR06 is coarser and harder than LR05, which is friable. The shellbed contains a large range of bivalves and gastropods. Key species are Alcithoe arabica, Dosinia greyi, Dosinia subrosea, Gari lineolata, and Tawera subsulcata. Occasional bivalves are articulated, and some Alcithoe arabica are encrusted with barnacles.

\subsubsection{Unit 3}

The highest exposure of the Longbush Road section is a package of sandstones and conglomerates. Unit 3 is $12.6 \mathrm{~m}$ thick, with no observed upper contact.

The lowest horizon of Unit 3, LR07, is a matrix-supported conglomerate (Fig. 4.13, B). The matrix is a fine to coarse sandstone. The clasts are indurated sandstone, less than 5 $\mathrm{cm}$ in size. The contact between this conglomerate and the underlying shellbed (LR06) is undulating with $30 \mathrm{~cm}$ of vertical relief.

Above the lowest conglomerate is yellow/brown, fine-grained sandstone (Fig. 4.13, B). Mudstone cracks were found on a farm track that cuts through LR08. Rare indurated sandstone clasts are found in this sandstone. This horizon is $1.2 \mathrm{~m}$ thick.

Due to vegetation, a $1 \mathrm{~m}$ section above LR08 lacks exposure. The outcrop continues with a second conglomerate (LR09), $2.5 \mathrm{~m}$ thick. This conglomerate ranges between clast and matrix-supported. Clasts are between 5- and 100-millimetres, subrounded to subangular. Over $90 \%$ are indurated sandstone, with occasional $(<10 \%)$ basalt clasts. The matrix is brown, coarse-grained sandstone.

The sandstone at the top of Unit 3 (Fig. 4.13, A) is pale brown with orange weathering. Fine to medium-grained with a silty texture, and bedded on a centimetre to decimetre scale. The upper contact is unobserved, giving a minimum thickness of $5.25 \mathrm{~m}$. 


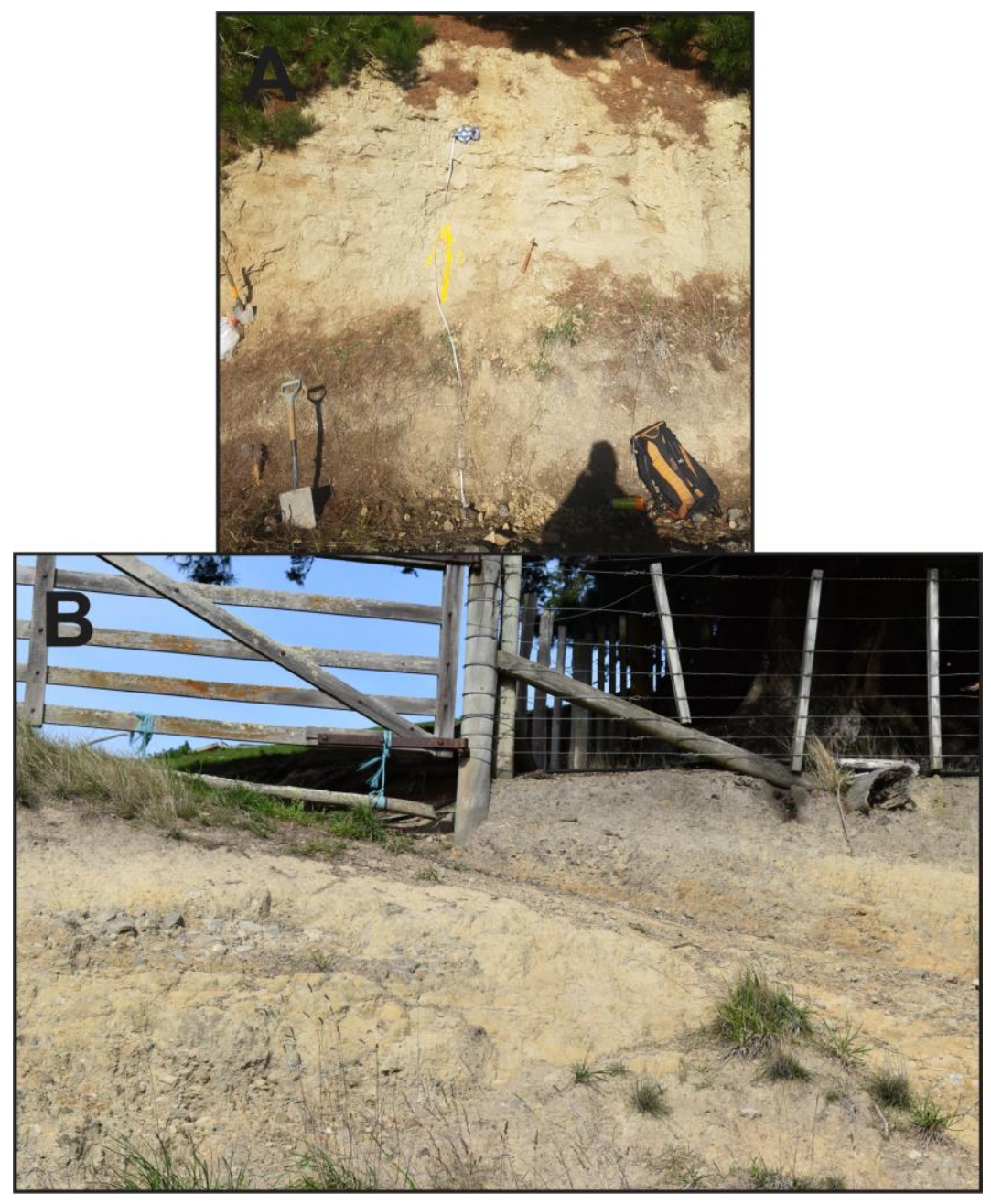

Figure 4.13: A: Sandstones of LR10, the highest exposure of the Longbush Road measured section. B: Sandstones and conglomerates of LR07 and LR08. Mudstone crack structures are present on the surface of the farm track.

\subsection{Correlation between measured sections}

Outcrop exposure between the Hinakura and Longbush Road outcrops is limited. This makes correlating between the two sections difficult. The majority of the exposure is adjacent to the two road outcrops, and only the upper part of the relevant stratigraphy has been identified (Te Muna Formation, Hautotara Formation, and upper Pukenui Limestone).

Fallen blocks of coquina form lines along hillsides, and are inferred to represent approximately in-situ beds of coquina from the Hautotara Formation, specifically the lowermost coquina referred to as the D Limestone (Rodley, 1961; Nowland, 2011). The evidence for this is cross-bedding in a cemented, sandy section at the bottom of blocks which have not been overturned. Nowland (2011) identifies cross-bedding in the $1 \mathrm{~m}$ 
shellbed ( $\mathrm{SB}_{1 \mathrm{x}}$ facies) immediately below the only limestone ( $\mathrm{SB}_{1}$ facies) observed in his Ruawaka Section. He notes that $\mathrm{SB}_{1 \mathrm{x}}$ facies are only observed directly underlying $\mathrm{SB}_{1}$ facies. As the limestone at the Ruawaka section is inferred to be stratigraphically equivalent to the D Limestone of Rodley (1961), the coquina outcropping between the Hinakura and Longbush Road measured sections is also labelled D Limestone.

The D Limestone does not outcrop as a well-cemented coquina at either the Hinakura Road or Longbush Road measured sections. This may be due to erosion, and therefore it would be amongst one of several sections of non-exposure.

The most obvious connection between the Hinakura and Longbush Road sections is the colour change from grey to brown observed in the upper section of the Pukenui Limestone. This is in the top two metres of HR18 of Unit 4 at the Hinakura Road section (Fig. 4.14, A) and between LR01 and LR02 of Unit 1 at the Longbush Road section (Fig. 4.14, B and C). The colour change has also been observed at one location between Hinakura and Longbush Road (Fig. 4.14, D), at Popes Head (Fig. 4.14, E), and other areas around the northern end of the Nga-Waka-A-Kupe Range.

A possibility exists that the observed colour change is a result of surficial weathering. The line representing the colour change appears to be parallel to bedding, providing evidence that it was formed during deposition. 


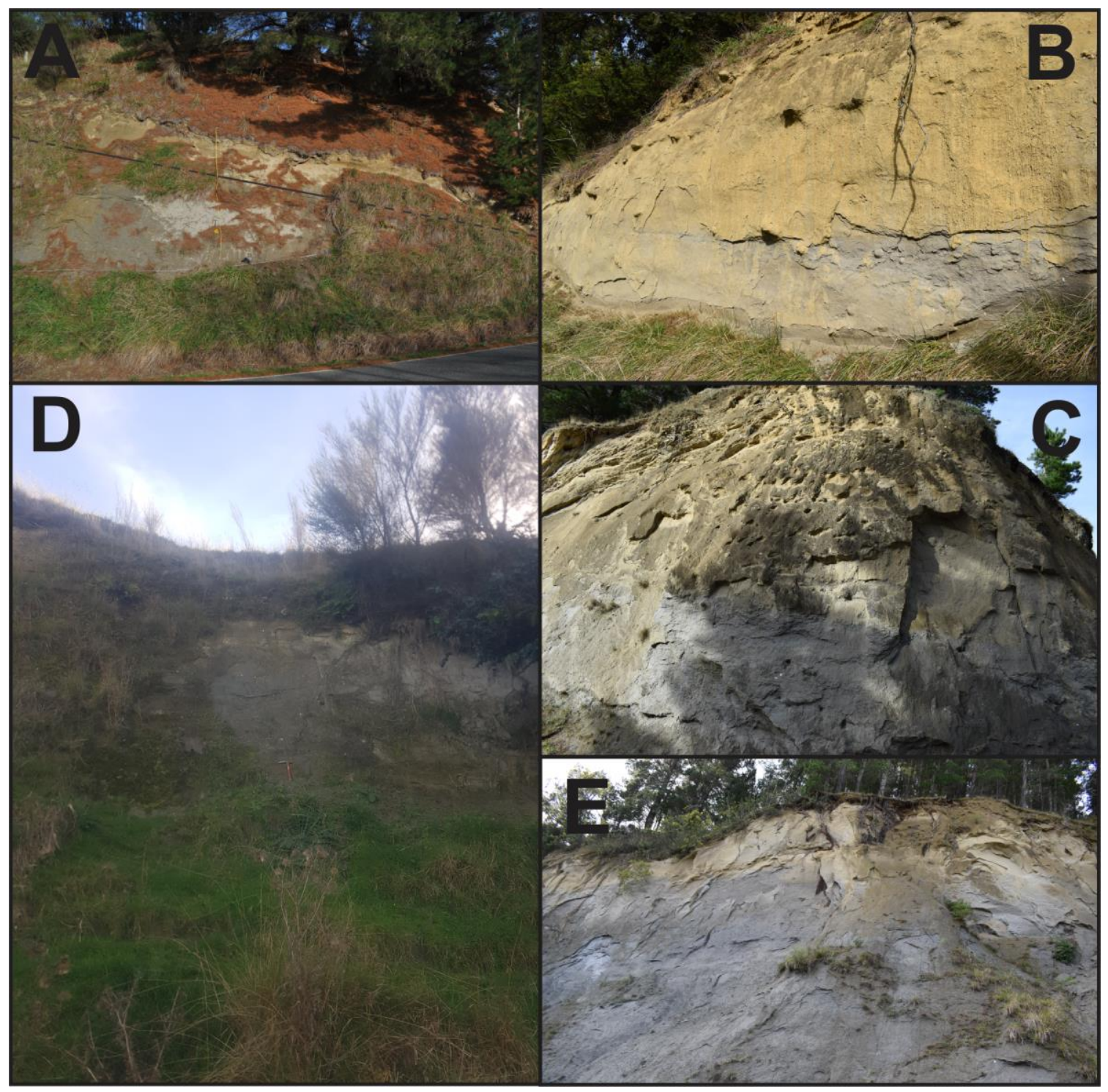

Figure 4.14: Colour change observed in outcrop at A: Unit 4 of Hinakura Road. B: Unit 3 of Longbush Road. C: A repeated sequence at Longbush Road. D: Field area between Hinakura and Longbush Road. E: Pope's Head

Figure 4.15 is a geological map which links the Hinakura and Longbush Road measured sections. Due to the lack of outcrop exposure, the majority of the map is inferred. Inferences were made by projecting layers using strikes and dips measured in field, structural data from previous studies, and the topography. 


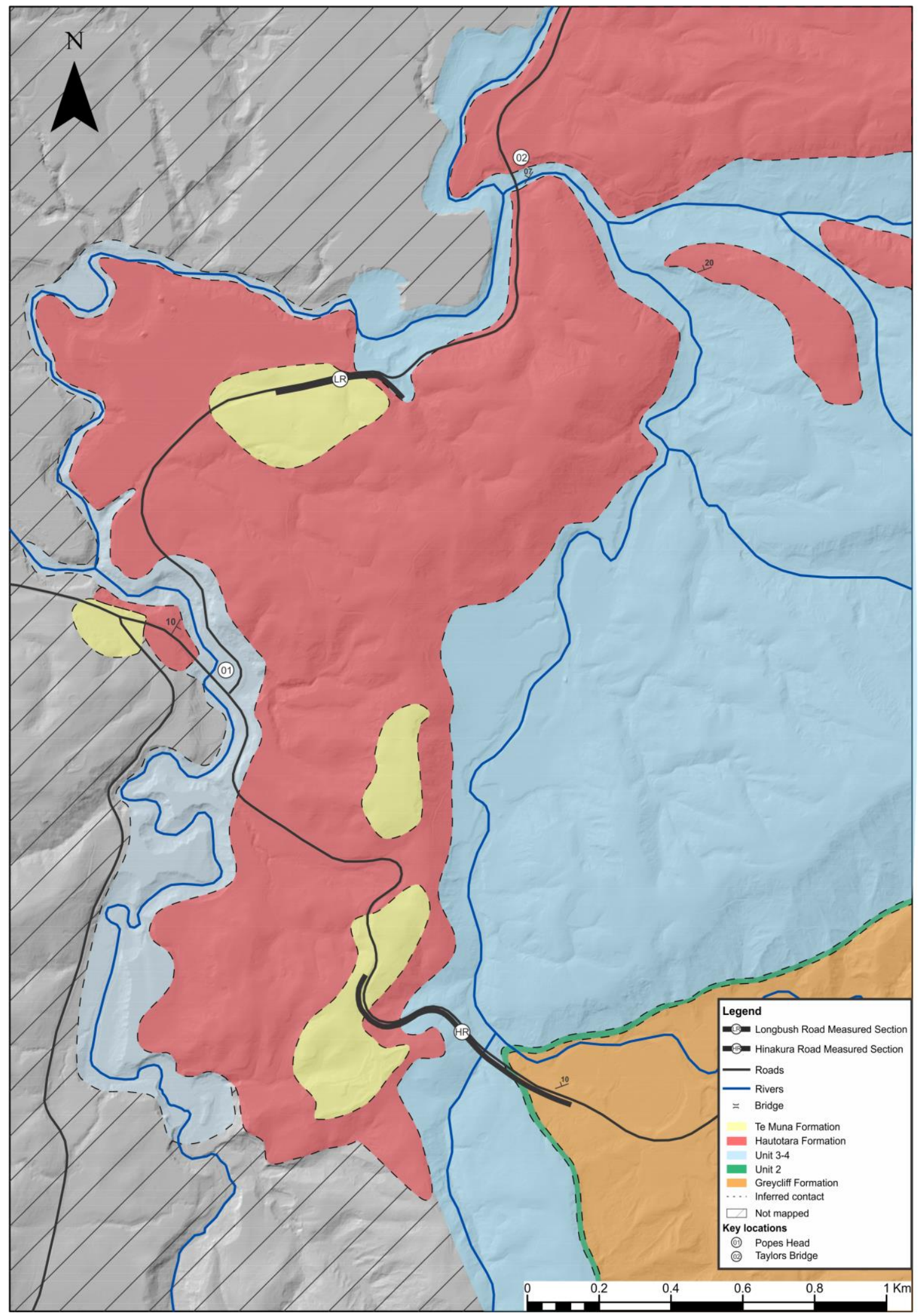

Figure 4.15: Geological map of the Popes Head area, showing Hinakura Road (HR) and Longbush Road (LR) measured sections 


\section{Chapter Five}

\section{Facies}

\subsection{General introduction}

Facies are defined as "a body of rock characterised by a particular combination of lithology, physical and biological structures that bestow an aspect different from the bodies of rock above, below and laterally adjacent" (Walker \& James, 1992).

A facies scheme is developed here to categorise the horizons within each measured section based on properties observable in the field, predominantly lithology and macrofauna content. Each facies reflects a depositional environment, interpreted by recognising lithological and paleontological characteristics and comparing them to the literature. The result of the facies scheme is to relate horizons from within the measured sections, so that deposits formed under similar depositional conditions can be recognised. The analysis was carried out for the Pukenui Limestone, Hautotara Formation, and base of the Te Muna Formation at the Popes Head (Fig. 1.1) area using both measured sections, and together these three analyses are integrated into a single depositional model.

Facies models have been described for the Pukenui Limestone and Hautotara Formation by previous authors, both near the study area and at the southern end of the Nga-WakaA-Kupe Range at the type section of the respective formations (e.g. Vella \& Briggs, 1971; Collen \& Vella, 1984; Rataul, 1988; Gammon, 1995; Rampton, 1997; Clarke, 1998; Nowland, 2011). Having a detailed facies scheme for both locations allows for a comparison of the depositional environment to be made between the type section location and this study.

Cycles found in Plio-Pleistocene sediments of the southern Wairarapa have been linked to glacio-eustatic sea-level change. Vella (1963) was the first to recognise that Wairarapa Plio-Pleistocene sediments are presented in repeated sedimentary packages representing natural cycles, or cyclothems, controlled by sea-level change. 


\subsubsection{Facies scheme}

The Hinakura Road and Longbush sections contain four main lithologies: sandstone, mudstone, shellbed, and conglomerate. In addition, two tephra were recorded within the Te Muna Formation and are included here as a part of the facies scheme. Where required each lithology has been subdivided into a series of subfacies.

\subsection{Sandstone Facies $-\mathrm{S}$}

Sandstone is the most common facies observed in the field area and is found in both measured sections. This facies is subdivided into four subfacies.

\subsubsection{Subfacies 1: Sn - Non-fossiliferous Sandstone}

The non-fossiliferous sandstone facies is typically grey/brown, fine to medium-grained, and very poorly sorted. In places, the Sn facies is silty. Centimetre to decimetre bedding is observed in the thicker $S_{n}$ beds, such as at Longbush Road. The beds at Hinakura Road are too thin to observe anything at this scale. $<5$-millimetre scale argillite clasts are common.

The non-fossiliferous sandstones are restricted to the Te Muna Formation. At the Hinakura Road section, they are between 10 and $25 \mathrm{~cm}$ thick. At the Longbush Road section, they are much thicker, reaching $5.25 \mathrm{~m}$. 


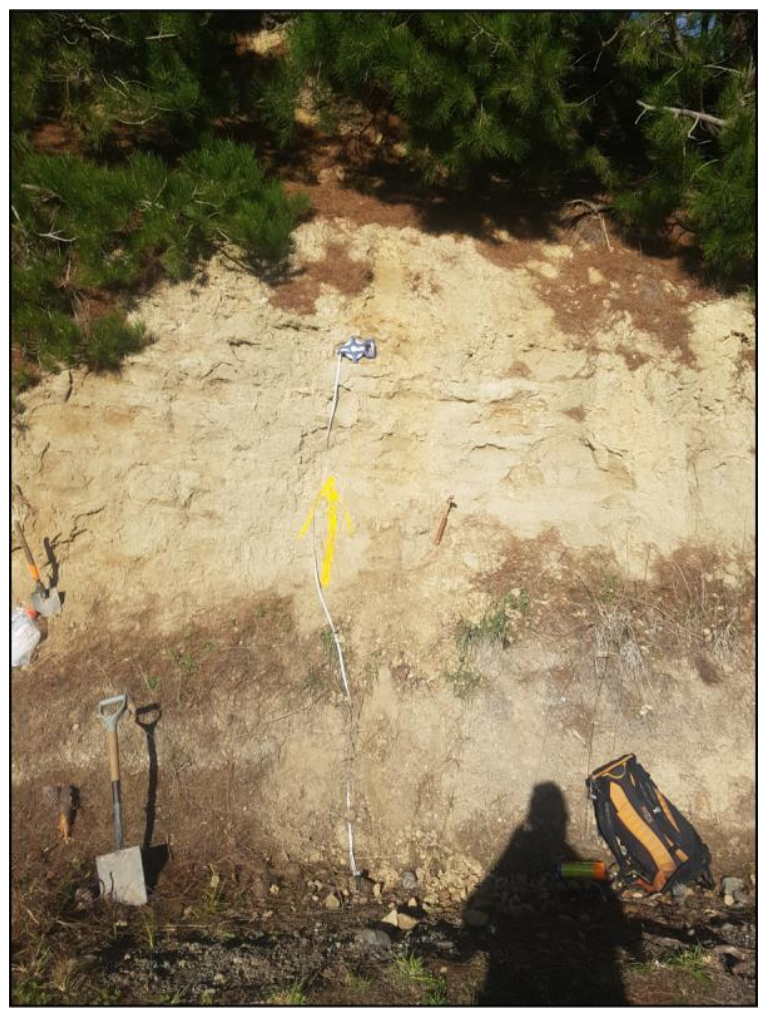

Figure 5.1: Non-fossiliferous sandstone $\left(S_{N}\right)$ facies at the Longbush Road measured section

\section{Depositional environment of $S_{N}$ Facies}

The depositional environment of $S_{N}$ facies is interpreted as occurring within a range of non-marine environments. These depositional settings include channel infill, lateral bars, and delta formation. Their depositional environment may explain the significant thickness variations.

\subsubsection{Subfacies 2: $\mathrm{S}_{\mathrm{D}}-$ Dosinia Sandstone}

The sandstones of this facies are typically brown to grey, fine to medium-grained, commonly muddy, moderately to poorly sorted and mostly firm. Most beds do not exhibit any structures, however, faint bedding is occasionally observed, on a centimetre scale.

$\mathrm{S}_{\mathrm{D}}$ beds contain whole and fragmented shells, including fine shell hash. Macrofossils are generally sparse, with rare whole specimen. Whole specimens are usually disarticulated. Common species are Dosinia subrosea, Dosinia greyi, Panopea sp., Pelicaria vermis, Pleuromeris sp., Talochlamys gemmulata, Tawera subsulcata, and Zethalia zelandica. 
Other fossil features are common in beds of the $S_{D}$ facies. These include burrows and bioturbation.

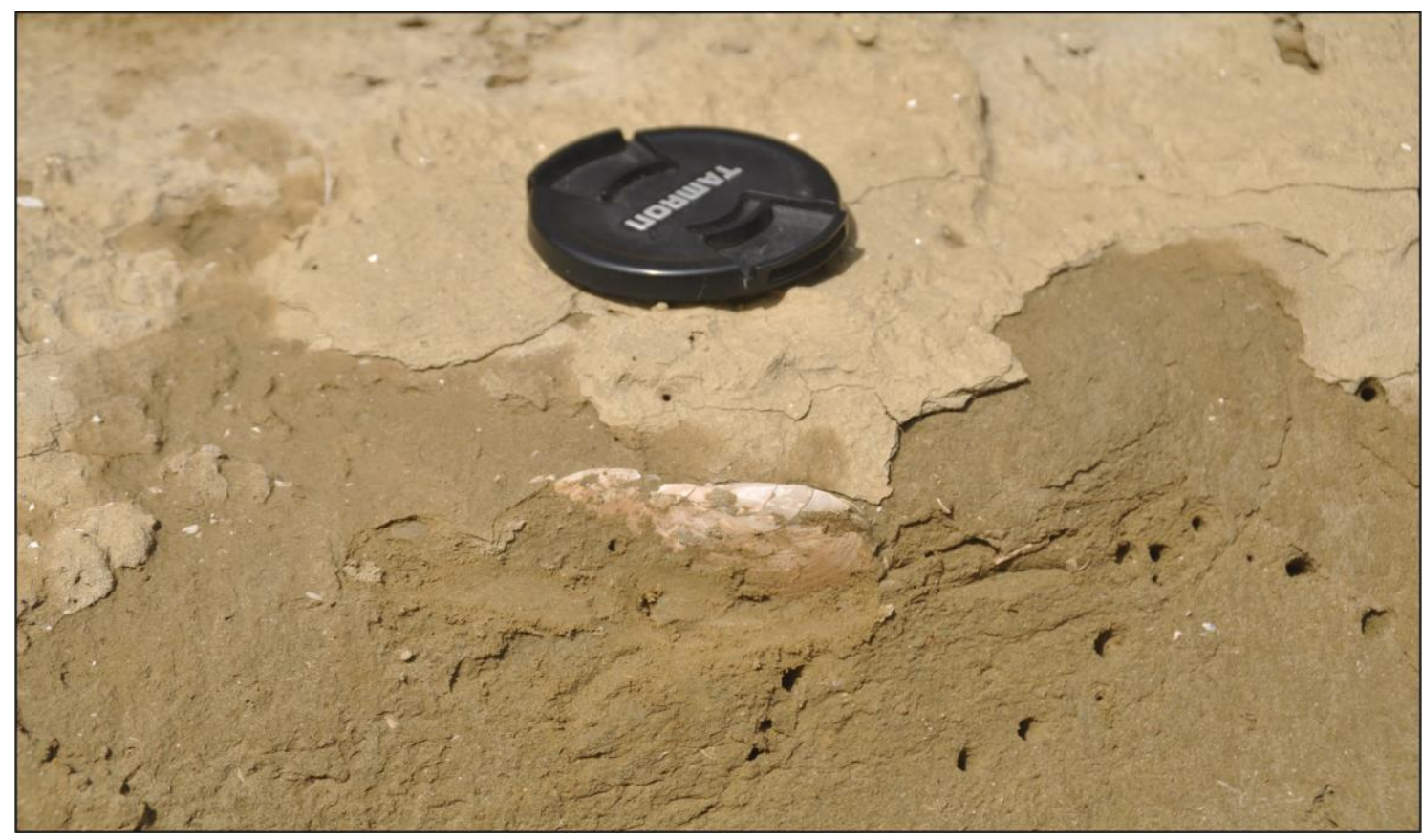

Figure 5.2: Dosinia sandstone ( $\left.\mathrm{S}_{\mathrm{D}}\right)$ facies at the Hinakura Road measured section

Depositional environment of $S_{D}$ facies

The fine to medium-grained lithology indicates a moderate energy within the depositional environment, however the muddy texture indicates low energy.

Talochlamys gemmulata indicate deposition below low tide to bathyal depths (Beu \& Maxwell, 1990). Dosinia subrosea and Zethalia zelandica indicate a near-shore, shallow water deposition off a sandy beach (McKnight, 1969; Beu \& Raine, 2009). Dosinia greyi inhabits a water depth range of 10-60 metres (Hendy \& Kamp, 2004). Pelicaria vermis are commonly found in subtidal depths (Neef, 1970).

The uncommon Austrovenus stutchburyi found in some units are interpreted as having been transported as dead shells from their typical estuarine setting and deposited among the sandstones of this facies.

$\mathrm{S}_{\mathrm{D}}$ facies are interpreted as being deposited in a shoreface setting. This is analogous with the $S_{d}$ facies of Nowland (2011). 


\subsubsection{Subfacies 3: $\mathrm{Sc}_{\mathrm{c}}$ - Coarse sandstone}

The coarse sandstone facies is a brown, coarse-grained, poorly sorted, moderately cemented, sparsely fossiliferous sandstone. Low angle trough cross-bedding is observed in some $\mathrm{S}_{\mathrm{C}}$ horizons. Mudstone rip-up clasts were observed in one horizon.

Whole macrofossils are rare throughout $\mathrm{S}_{\mathrm{C}}$ horizons, but fine shell hash is common. Species present are dominantly Dosinia sp., Dosina sp., and Zethalia zelandica.

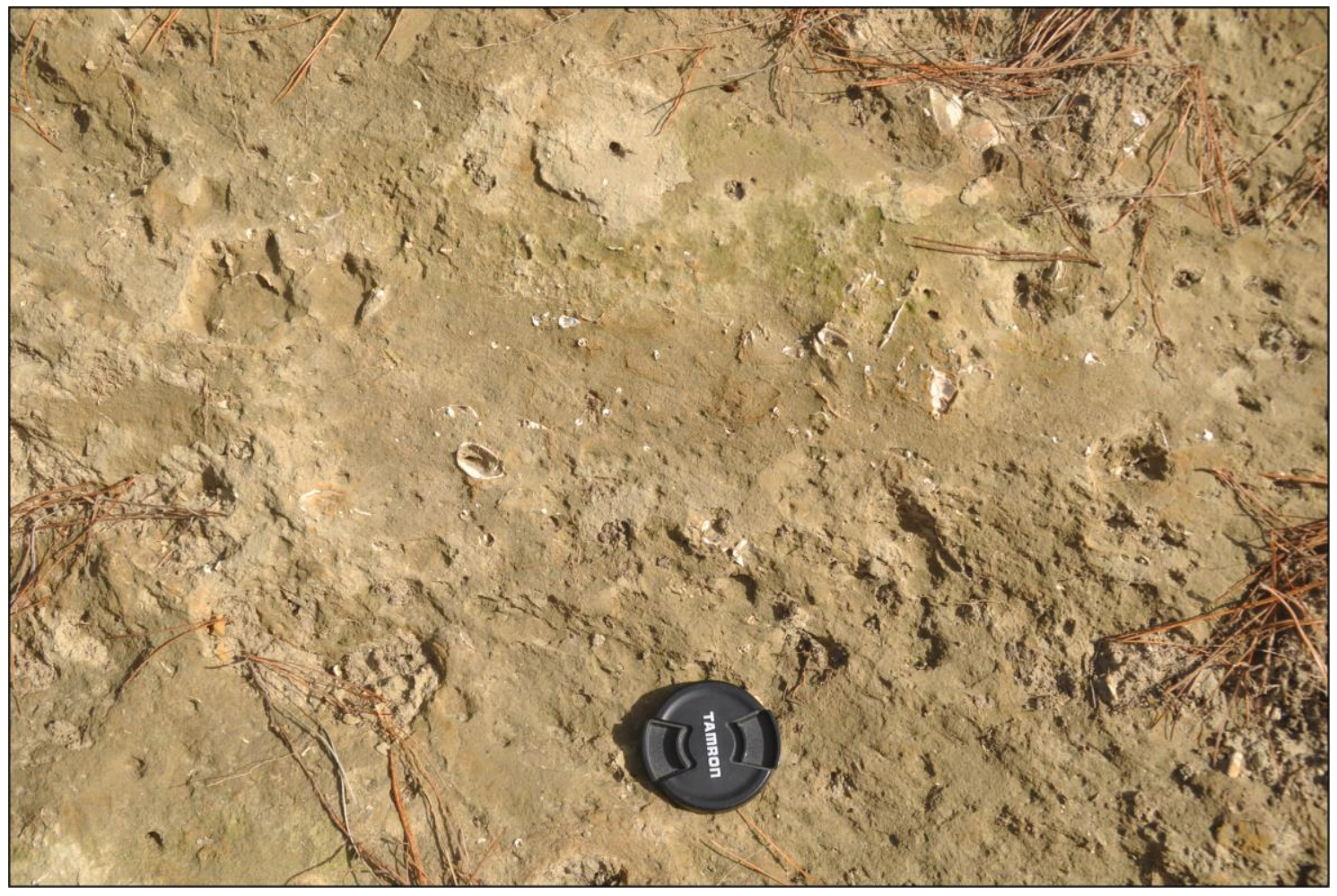

Figure 5.3: Coarse sandstone $\left(\mathrm{Sc}_{\mathrm{C}}\right)$ facies at the Hinakura Road measured section

\section{Depositional environment of $S_{C}$ facies}

Zethalia zelandica is a shallow-water species, usually 3-5 metres water depth, preferring moderate to high-energy environments such as the wave zone off slightly protected sandstone beaches (Beu \& Maxwell, 1990). Dosinia species are common in foreshore and shoreface environments (Beu \& Maxwell, 1990). The abundant fine shell hash is indicative of a high energy environment.

Deposition of this facies is inferred to have occurred in an intertidal to subtidal environment. The macrofossils indicate a beachface to shoreface setting. Changes in grainsize, sorting, and faunal content are expected due to variations in depth and energy 
of deposition. The $\mathrm{S}_{\mathrm{C}}$ facies of this study is analogous to the $\mathrm{S}_{\mathrm{W}}$ (Well Sorted) facies of Nowland (2011).

\subsubsection{Subfacies 4: Ss/M - Alternating sandstone/mudstone}

This facies is characterised by beds that are made up entirely of alternating sandstone and mudstone, usually on a $10 \mathrm{~cm}$ scale. Occasional horizons are 0.75 to $1.0 \mathrm{~m}$ of only sandstone or mudstone, but within a package of $10 \mathrm{~cm}$ bedded sandstone and mudstone. This facies is entirely non-fossiliferous.

This facies is recorded only from Hinakura Road Unit 2. Unit 2 is very poorly preserved and exposed, making detailed descriptions difficult. As such, there is a lack of data from which to determine environments.

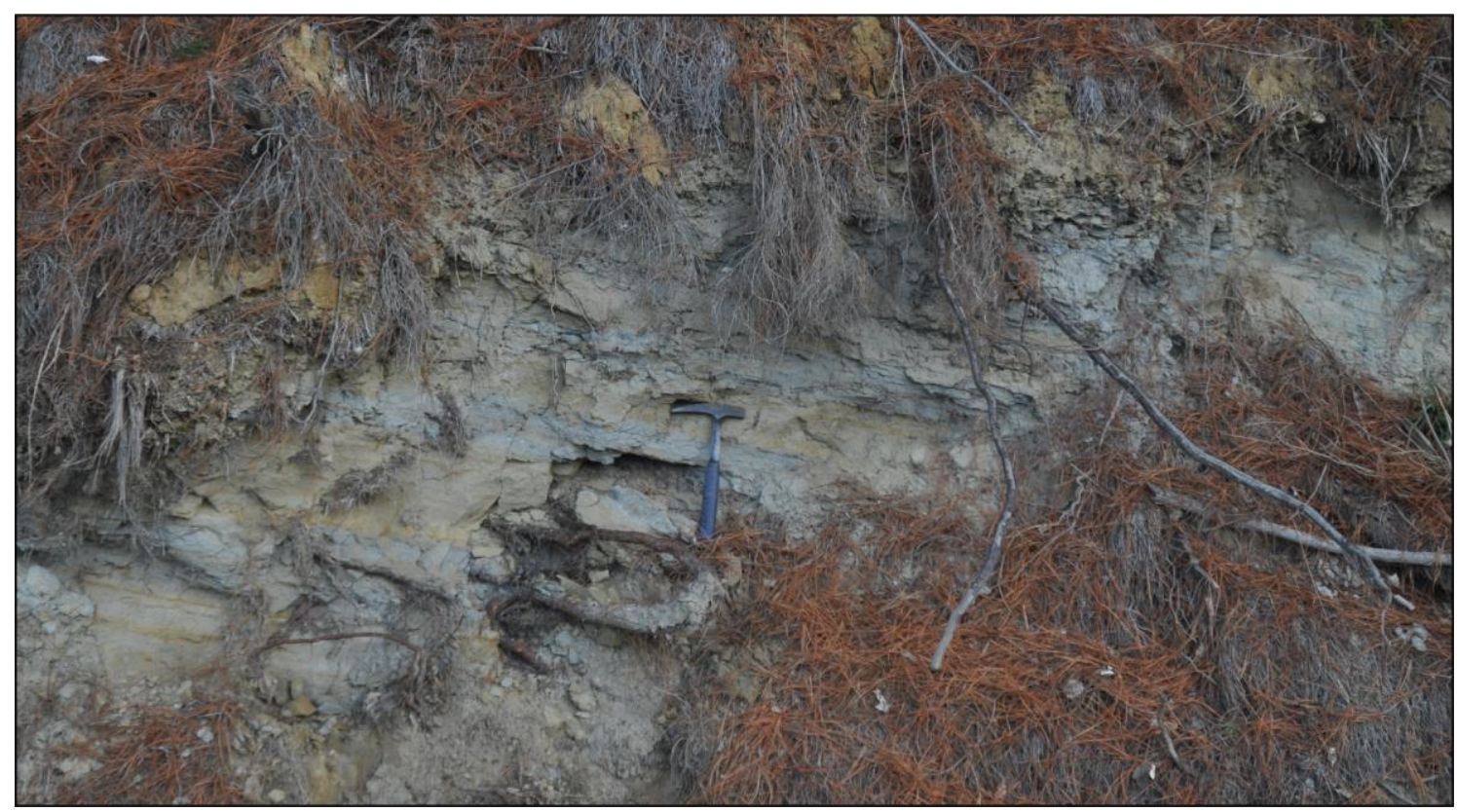

Figure 5.4: Alternating fine sandstone and mudstone of the $S_{S / M}$ from Unit 2 of the Hinakura Road measured section

\section{Depositional environment of $S_{S / M}$ facies}

Because $\mathrm{S}_{\mathrm{S} / \mathrm{M}}$ facies are always bound by marine units and there is a lack of terrestrial indicators such as terrestrial fossils or conglomerates, these facies are interpreted to be marine. The alternating mudstone and fine sandstone is an indication that the energy of the depositional setting was alternating. The mudstone indicates a low energy environment. As the majority of the sandstone is fine grained and muddy, the 
environment must not have experienced a significant increase in energy. The lack of any clasts also supports the lack of a high-energy environment.

\subsection{Mudstone Facies - M}

Mudstone units are common throughout the Pukenui Limestone and Te Muna Formation at both sections. They represent a range of water depths and include both marine and terrestrial facies. This facies is subdivided into two subfacies.

\subsubsection{Subfacies 1: Ms - Sandy mudstone}

The sandy mudstone facies $\left(\mathrm{M}_{\mathrm{S}}\right)$ is a pale grey, massive, non-fossiliferous sandy mudstone. Clay beds are recorded in some $\mathrm{M}_{\mathrm{S}}$ horizons. $\mathrm{M}_{\mathrm{S}}$ facies are mostly massive, however laminations are evident in several horizons. No fossils have been observed in any $\mathrm{M}_{\mathrm{S}}$ mudstones, however a lignite layer was observed at the base of a $\mathrm{M}_{\mathrm{S}}$ horizon at the Hinakura Road outcrop, separating it from an underlying tephra. Iron nodules are recorded in at least one $\mathrm{M}_{\mathrm{s}}$ horizon.

The $\mathrm{M}_{\mathrm{S}}$ facies has only been recorded in the Te Muna Formation. Most horizons are approximately $1 \mathrm{~m}$ thick. Nowland (2011) records thicker mudstones of the same facies further to the south, thickest at the type section reaching 6 m Collen \& Vella (1984) record similar mudstone facies up to $20 \mathrm{~m}$ thick at the type section. At the Hinakura Road outcrop $M_{S}$ facies always overly $S_{N}$ and underlie $C_{m}$ facies. No $M_{S}$ facies were recorded at the Longbush Road outcrop. 


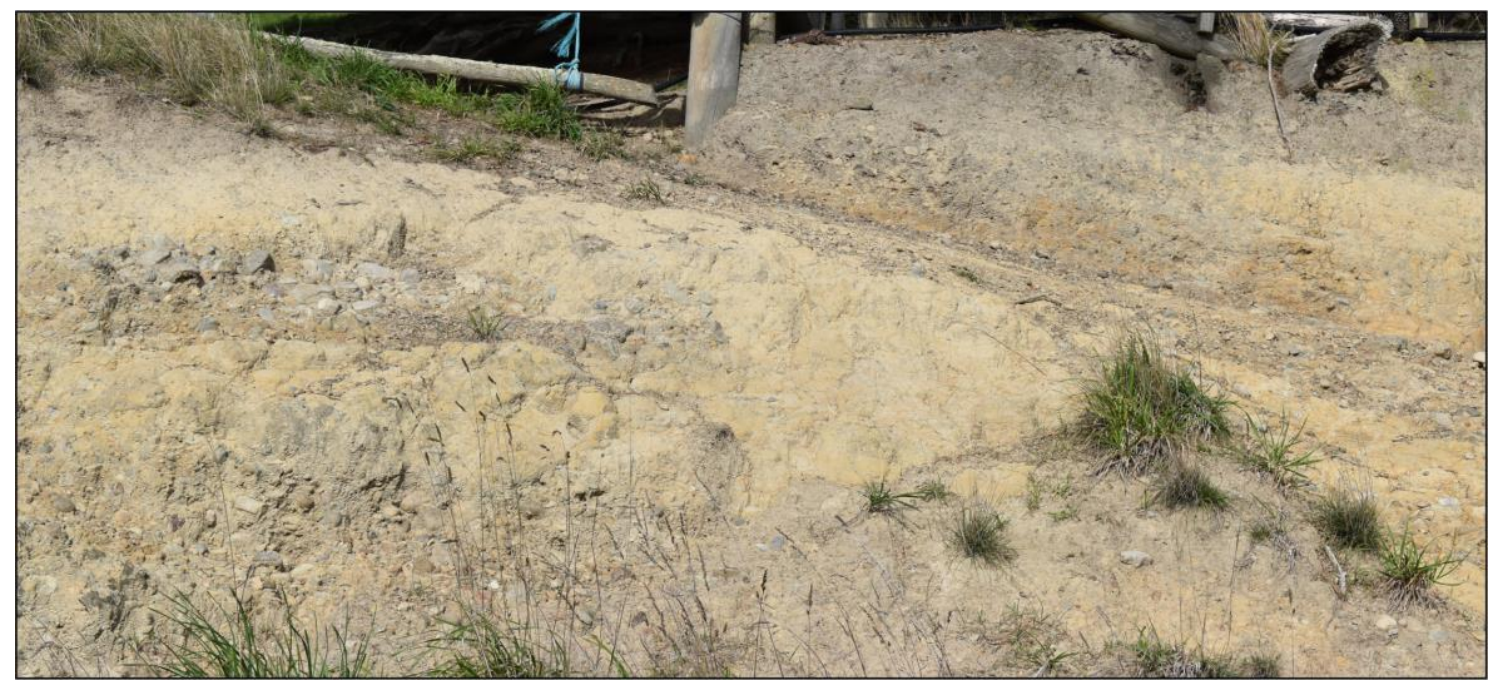

Figure 5.5: Beds of sandy mudstone (Ms) facies interbedded with conglomerate at the Longbush Road measured section

\section{Depositional environment of $M_{S}$ facies}

The $M_{S}$ facies of this study are comparable to the $M_{S}$ facies of Nowland (2011) and the $\mathrm{M}_{\mathrm{vii}}-\mathrm{M}_{\mathrm{viii}}$ facies of Woolfe (1993). The lack of any marine fossils, combined with the presence of a centimetre lignite interbed in at least one mudstone indicates a terrestrial deposition. Laminations in some beds indicates deposition in a low energy environment where bioturbation has not disturbed any laminae (Boggs, 2006). Combined with the lack of marine fossils this is interpreted as lacustrine. Nowland (2011) observed pyrite and jarositic discolouration. As these develop in anoxic conditions the depositional environment must have been quiet with a lack of mixing. Changes from clay-rich to sandstone-rich mudstone is interpreted as the result of sediment supply.

Following Nowland (2011) the $\mathrm{M}_{\mathrm{S}}$ facies are interpreted as having been deposited in a lacustrine setting, such as would be found in Lake Wairarapa today. The Lake Wairarapa setting is typical during an interglacial and highstand period. Therefore, $\mathbf{M}_{\mathrm{s}}$ facies are interpreted as having occurred during a highstand.

\subsubsection{Subfacies 2: $M_{F}$ - Fossiliferous Mudstone}

The $\mathrm{M}_{\mathrm{F}}$ facies are dominantly a blue/grey mudstone. It is usually massive, however one section of weak lamination has been observed in the top $50 \mathrm{~cm}$ of HR04. Only one horizon in Unit 2 at Hinakura Road is assigned to $\mathrm{M}_{\mathrm{F}}$ (HR04). 
Species present within the $\mathrm{M}_{\mathrm{F}}$ facies are Atrina zelandica, Pratulum pulchellum, Scalpomactra scalpullum, and Zeacolpus vittatus.

\section{Depositional environment of $M_{F}$ facies}

The muddy lithology and marine fossils indicates deposition in a low energy marine environment. Fossils identified represent a selection of marine species commonly found in shallow water, typically low energy, and on the most part preferring enclosed bays. The section of $\mathrm{M}_{\mathrm{F}}$ facies that includes laminations exhibits a decrease in the number of fossils. As with the $\mathrm{M}_{\mathrm{s}}$ facies, the laminations and lack of fossils indicates a low energy environment. The presence of fossils in the lower section indicates that the depositional setting was still marine. A lack of conglomerates bounding these facies is an indication that deposition did not occur in a lacustrine setting such as Lake Wairarapa or Onoke as indicated by $\mathrm{M}_{\mathrm{S}}$ facies.

Atrina zelandica are common in coastal and estuarine settings, preferring waters lacking suspended sediment. The low abundance of Atrina zelandica recorded in $\mathrm{M}_{\mathrm{F}}$ facies is an indication that an increase in suspended sediment was present during deposition (Ellis et al., 2002). Pratulum pulchellum are common in a range of water depths, which include small bays in harbours to outer shelf, and are usually an indicator of fine-grained substrates (Beu \& Maxwell, 1990). Scalpomactra scalpellum are indicative of fine sandstone sheltered bays with a water depth of 5-9 metres (Hayward et al., 1986).

\subsection{Shellbed Facies - SB}

Two shellbed subfacies are observed in the sections measured in this study. They are differentiated predominantly by the macrofauna. These facies are restricted to the Pukenui Limestone and Hautotara Formation.

\subsubsection{Subfacies 1: $\mathrm{SB}_{\mathrm{A}}$ : Austrovenus shellbed}

This facies consists of a fine, medium-grained, poorly sorted, sandstone matrix. It is well cemented and usually very hard. 2-millimetre argillite clasts and shell hash are common in all $\mathrm{SB}_{\mathrm{A}}$ beds. 
Fauna are densely packed, in most areas bioclast supported. The macrofossils are dominantly shallow marine species, including estuarine restricted species such as Austrovenus stutchburyi, Ruditapes largillierti, and Dosinia subrosea.

Presence of Psychrochlamys delicatula in HR02 and HR06 and Jacquinotia edwardsii in HR06 indicate cold water.

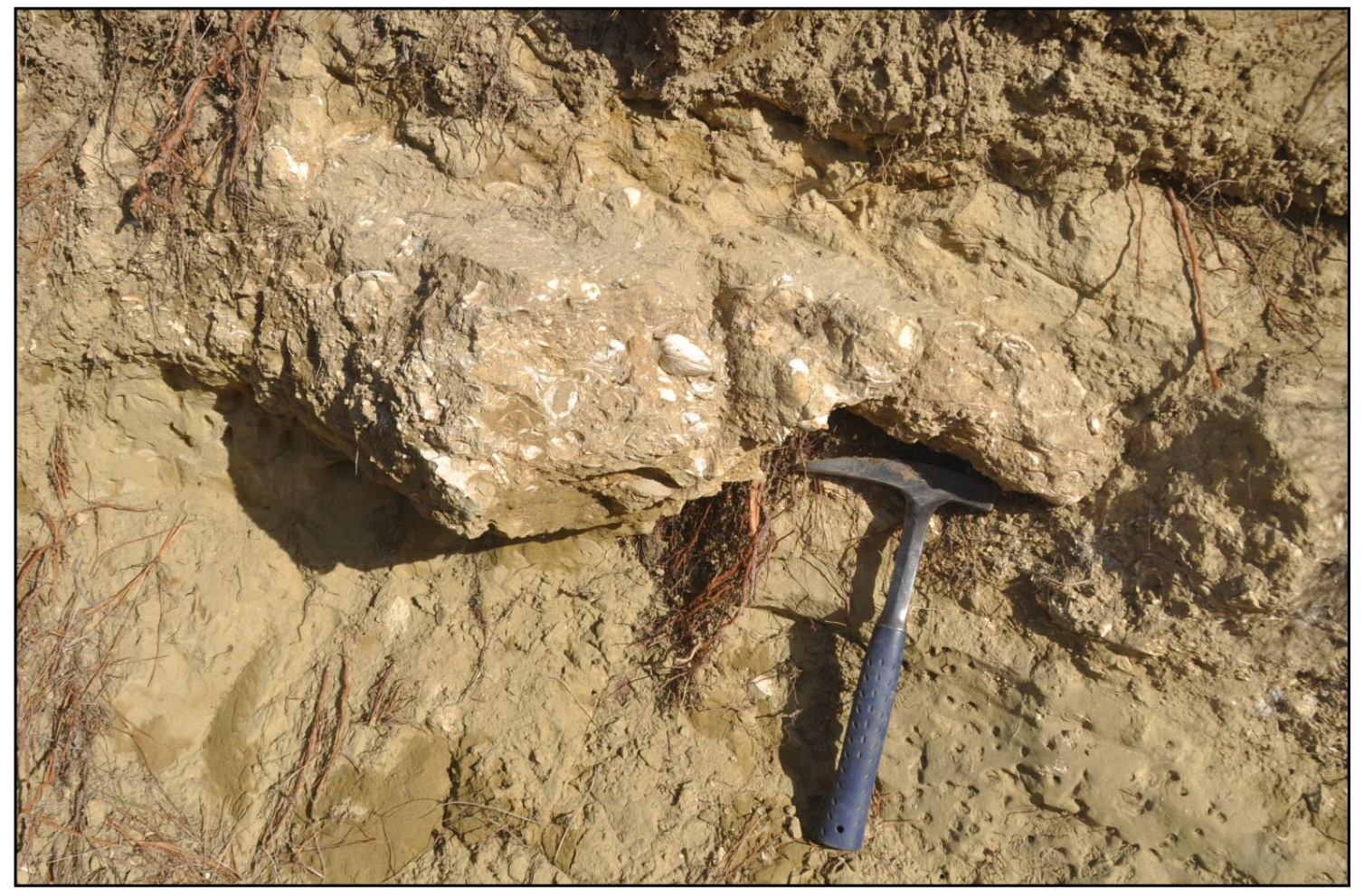

Figure 5.6: Austrovenus shellbed $\left(\mathrm{SB}_{\mathrm{A}}\right)$ of Unit 2 at the Hinakura Road measured section

\section{Depositional environment of $S B_{A}$ facies}

The species of fauna present represent a wide range of environments, however they most commonly include estuarine species. This is supported by the presence of Austrovenus stutchburyi, Dosinia subrosea, and Ruditapes largillierti, which are all dominantly estuarine restricted species (Beu \& Raine, 2009). Other species such as Alcithoe arabica, Ostrea chilensis, Stiracolpus symmetricus, Talochlamys gemmulata, and Tawera subsulcata are further indication of a shallow water environment (Beu \& Raine, 2009). Ruditapes largillierti and Stiracolpus symmetricus are also common in large bays (Beu \& Raine, 2009). 
The presence of small argillite clasts indicate that there was influence from a low to moderate energy source that drained a local topographic argillite high. This would likely have been the Aorangi Range to the southeast.

The $\mathrm{SB}_{\mathrm{A}}$ facies are interpreted as being deposited in a shallow marine, low to moderate energy environment such as an enclosed bay. This environment was under the influence of a river.

Despite being called the Austrovenus shellbed, Austrovenus stutchburyi need not be present. As long as the overall species present indicates an estuarine deposition, the facies are considered $\mathrm{SB}_{\mathrm{A}}$.

\subsubsection{Subfacies 2: $\mathrm{SB}_{\mathrm{T}}$ : Tawera subsulcata dominated shellbed}

This facies is dominantly brown, sometimes blue-grey on some fresh surfaces. The matrix is medium to coarse grained, poorly sorted, and moderately to well cemented. Millimetre to centimetre scale clasts of argillite and quartz are common.

The faunal content is dominantly Tawera subsulcata, which are extremely abundant. One specimen each of Myadora striata, Pelicaria vermis, Talochlamys gemmulata, and Alcithoe sp. were identified at the Hinakura Road section. 


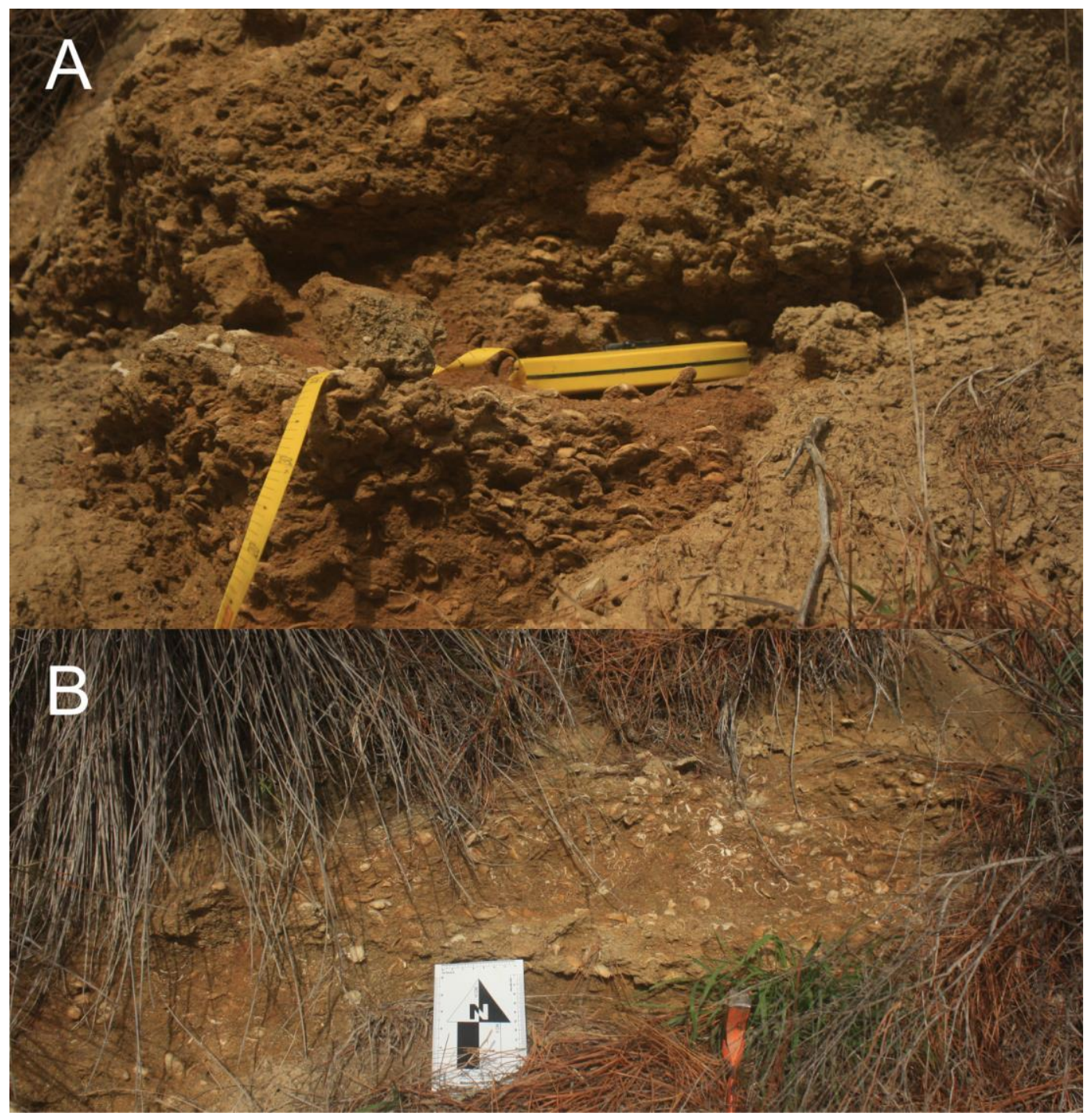

Figure 5.7: Tawera Shellbed from the top (A) and bottom (B) of HR26 (Enclosure A), Unit 4, Hinakura Road representing facies $S_{B}$

Nowland (2011) describes a facies labelled $\mathrm{SB}_{\mathrm{t}}$ (analogous to the $\mathrm{SB}_{\mathrm{T}}$ of this study), which included the outcrop shown in Figure 5.7. His interpretation was based on Tawera spissa, a modern relative of Tawera subsulcata living around New Zealand today, found along exposed coastal beaches in 10 to $50 \mathrm{~m}$ of water (McKnight, 1969).

The presence of clasts indicates that deposition was in a moderate to high-energy environment proximal to land and likely a river mouth. As such, deposition is interpreted to occur in a higher energy environment than $\mathrm{SB}_{\mathrm{A}}$ facies, near the output of a river. 


\subsection{Conglomerate Facies - C}

Only one conglomerate facies is identified in either of the sections measured for this study, labelled C. It is restricted to and is the dominant facies of the Te Muna Formation. The $\mathrm{C}$ facies of this study is comparable to $\mathrm{C}_{\mathrm{m}}$ (massive-to-stratified conglomerate) of Nowland (2011).

The matrix is yellow to brown fine sandstone. The clasts of the conglomerate facies are 5 to $90 \mathrm{~mm}$, averaging $20 \mathrm{~mm}$. Most are rounded to sub-rounded, with occasional subangular clasts. Clasts are dominantly argillite with occasional igneous clasts $(<1 \%)$ present. Nowland (2011) also identified chert and bored mudstone clasts. Faint $0.5 \mathrm{~m}$ bedding was observed in the $\mathrm{C}$ facies at Hinakura Road. Faint imbrication is evident in most $\mathrm{C}$ beds, usually indicating a flow direction between west and north. Orange to brown weathering is occasionally observed. The $\mathrm{C}$ facies varies between matrix and clast supported.

The $\mathrm{C}$ beds of this study reach a maximum thickness of 3 metres. Collen and Vella (1984) record a maximum thickness of $\sim 40$ metres. The lower contact of the conglomerate beds was only observed once. The contact was undulating over $30 \mathrm{~cm}$ with a $10 \mathrm{~cm}$ amplitude. No fossils were observed, however Nowland (2011) recorded rare logs and branches in the equivalent facies at sections to the south. 


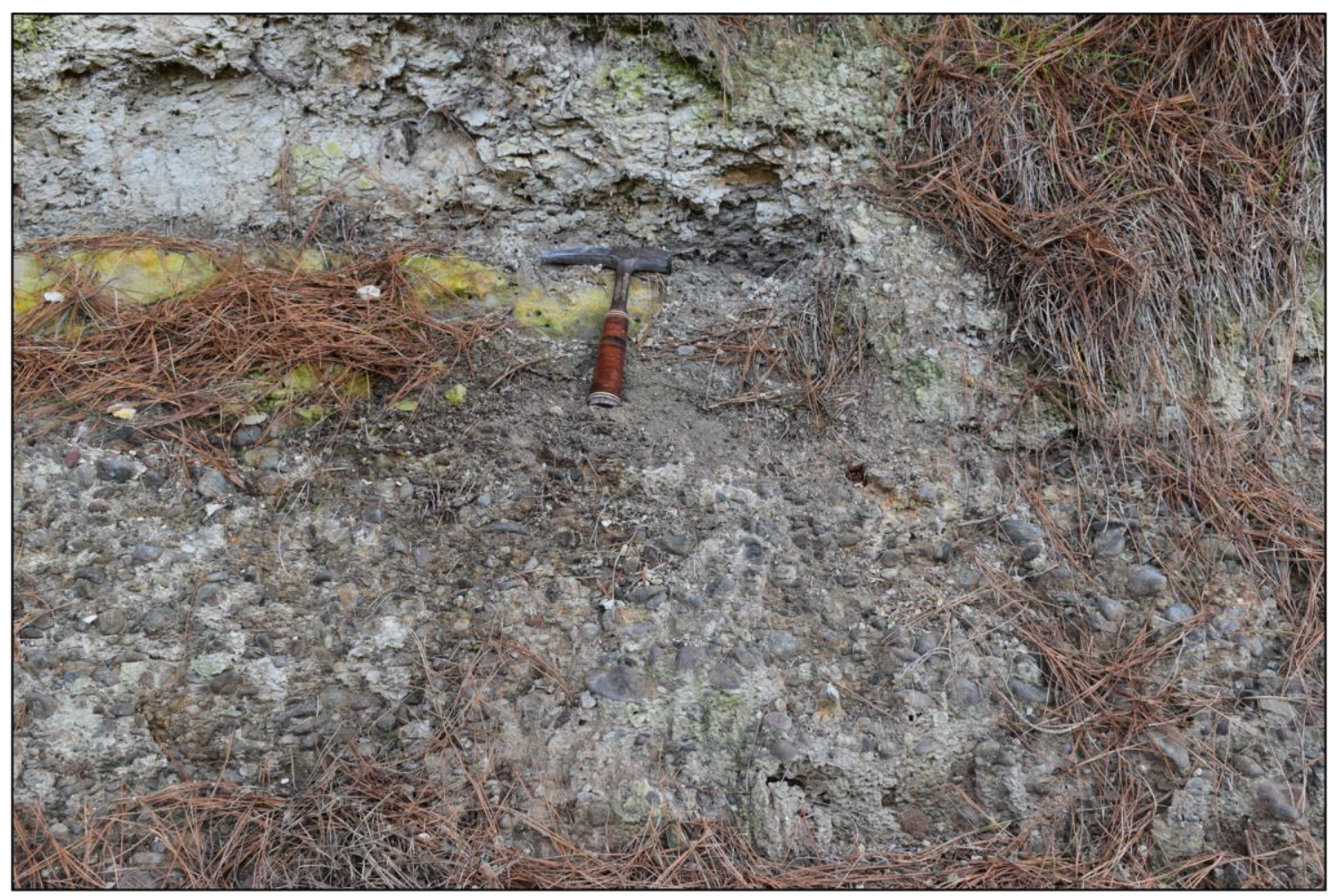

Figure 5.8: Conglomerate from $\mathrm{C}$ facies are the Hinakura Road measured section. Coloured layer to left of hammer is tephra

\section{Depositional environment of C Facies}

The shape and size of the clasts, as well as the imbrication, indicates that these conglomerates were deposited in a braided river system. Nowland (2011) recorded much larger clast sizes (to $\sim 28 \mathrm{~cm}$ ) in the same facies at the southern end of the NgaWaka-A-Kupe Range. Stratified gravels were likely rapidly deposited in channels or the central portion of bars (Browne \& Naish, 2003).

Nowland (2011) came to the same conclusion for Te Muna conglomerates, both north of the Nga-Waka-A-Kupe Range and at the type area. He noted that the gravels of the Te Muna Formation were comparable to the $G_{m}$ and $G_{p}$ facies described by Browne and Naish (2003) in terrestrial deposits of the Canterbury Plains.

$\mathrm{C}$ facies have only been recorded in the Te Muna Formation (this study; Nowland, 2011). Collen \& Vella (1984) noted that sorting and roundness of clasts within similar conglomerates decrease with stratigraphic height, while clast size increases (Rampton, 1997). Nowland (2011) recorded the same clasts trends up-section and to the south. 


\subsection{Tephra - V}

The two tephra from the Hinakura Road measured section were described and interpreted by Nowland (2011), labelled the Hinakura Road Lower (HR $)$ and Upper $\left(\mathrm{HR}_{\mathrm{u}}\right)$ Tephra.

The lower tephra is pink to grey and laminated, and the upper tephra is yellow to white with no structures observed. The two tephra are located at the highest exposure on the Hinakura Road measure section, amongst sandstones, mudstones, and conglomerates of the Te Muna Formation.

Major element analysis by Nowland (2011) showed that the two Hinakura Road tephra can be correlated to a number of tephra from the Whanganui Basin and ODP Core 1123 . The astronomically tuned Ridge (1.56 Ma), Maranoa (1.63 Ma), and Birdgrove (1.60 Ma) Tephra are chemically indistinguishable from $\mathrm{HR}_{1}$ and $\mathrm{HR}_{\mathrm{u}}$ (Pillans et al., 2005, in Nowland, 2011). Shane et al. (1996) dated the nearby Akupe Tephra as $1.64 \pm 0.16 \mathrm{Ma}$, which supports the age for the other tephra in the area.

Three samples, AT-382, AT-383, and AT-407 are also indistinguishable from the Hinakura Road tephra, and are therefore also correlatives (Nowland, 2011). They provide ages of 1.566 Ma (AT-382), 1.584 Ma (AT-383), and 1.532 Ma (AT-407), which are interpreted as being similar to the age of $1.64 \pm 0.16$ Ma provided for the Akupe Tephra (Allan et al., 2008; in Nowland, 2011).

Unlike previous studies (Shane \& Froggatt, 1991), Nowland (2011) interprets both tephra as individual depositions, rather than a single reworked depositional event. This study agrees with Nowland (2011) on the basis that the two tephra are separated by $4 \mathrm{~m}$ of alternating facies. To deposit one tephra interbedded with $4 \mathrm{~m}$ of mud and conglomerate is unlikely. 
Table 5.1: Tabular summary of facies

\begin{tabular}{|c|c|c|c|c|}
\hline \multicolumn{2}{|c|}{ Facies } & Features & $\begin{array}{c}\text { Characteristic } \\
\text { Fauna }\end{array}$ & $\begin{array}{c}\text { Interpreted } \\
\text { Paleoenvironment }\end{array}$ \\
\hline \multirow{4}{*}{ 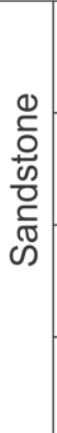 } & $S_{n}$ & $\begin{array}{l}\text { fine-medium grained, } \\
\text { Torlesse clasts, } \\
\text { non-fossiliferous }\end{array}$ & & $\begin{array}{l}\text { Terrestrial, fluvial, } \\
\text { braided river }\end{array}$ \\
\hline & $\mathrm{S}_{\mathrm{D}}$ & $\begin{array}{l}\text { muddy-medium } \\
\text { grained }\end{array}$ & $\begin{array}{c}\text { Dosinia subrosea and greyi, } \\
\text { Talochlamys gemmulata, } \\
\text { Zethalia zelandica }\end{array}$ & Shoreface \\
\hline & $\mathrm{S}_{\mathrm{c}}$ & $\begin{array}{l}\text { Coarse grained, } \\
\text { cross-bedded }\end{array}$ & $\begin{array}{c}\text { Dosina sp., Dosinia sp., } \\
\text { Zethalia zelandica }\end{array}$ & Beachface to shoreface \\
\hline & $\mathrm{S}_{\mathrm{S} / \mathrm{M}}$ & $\begin{array}{l}\text { 10cm bedding } \\
\text { alt. sst/mst }\end{array}$ & & Marine, low energy \\
\hline \multirow{2}{*}{ 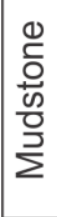 } & $\mathrm{M}_{\mathrm{S}}$ & Laminated, sandy & $\begin{array}{l}\text { Lignite, } \\
\text { no marine fossils }\end{array}$ & Lacustrine \\
\hline & $\mathrm{M}_{\mathrm{F}}$ & Massive & $\begin{array}{c}\text { Atrina zelandica, } \\
\text { Pratulum pulchellum, } \\
\text { Scalpomactra scalpellum }\end{array}$ & Estuarine/enclosed bay \\
\hline \multirow{2}{*}{$\begin{array}{l}\bar{D} \\
\Phi \\
\stackrel{\varrho}{\bar{d}} \\
\frac{\stackrel{c}{\omega}}{\omega}\end{array}$} & $\mathrm{SB}_{\mathrm{A}}$ & $\begin{array}{l}\text { Torlesse clasts, } \\
\text { dense macrofossils }\end{array}$ & \begin{tabular}{|c|} 
Austrovenus stutchburyi, \\
Dosinia subrosea, Psychrochlamys \\
delicatula, Ruditapes largillierti
\end{tabular} & Estuarine \\
\hline & $\mathrm{SB}_{\mathrm{T}}$ & $\begin{array}{l}\text { Well cemented, } \\
\text { fossil rich }\end{array}$ & Tawera subsulcata & Influenced by a river \\
\hline ठ் & C & $\begin{array}{l}5-90 \mathrm{~mm} \text { clasts, } \\
\text { faint imbrication, }\end{array}$ & & $\begin{array}{l}\text { Terrestrial, fluvial, } \\
\text { braided river }\end{array}$ \\
\hline 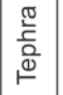 & V & Faintly bedded & & Swamps, lacustrine \\
\hline
\end{tabular}




\section{Chapter Six \\ Discussion}

\subsection{General introduction}

In this chapter, the units recognised in the Hinakura and Longbush Road measured sections are compared to those at the type sections. This includes correlating them stratigraphically. The Longbush Road section is of limited value due to the lack of exposure, and therefore is only used sparingly to supplement the upper units of the Hinakura Road section.

Two drivers are proposed as explanations for the facies change observed between the type locality and the Popes Head area. Following the two proposed drivers is an explanation of why one driver alone is insufficient, and how a combination of the two is likely. Additionally, an attempt to refine the age of the Pukenui Limestone and Hautotara Formation is made.

\subsection{Facies model}

Figure 6.1 is a schematic representation of the facies identified within the measured section of this study. It shows how they relate to one another horizontally through space and vertically through time. Its purpose is to portray how the facies are laterally adjacent, and how given time they can form the vertically stacked succession of facies observed in the outcrop. It is not an exact reproduction of how the environment would have looked 1.5-2.0 Ma, but rather a tool to represent the relevant facies. 


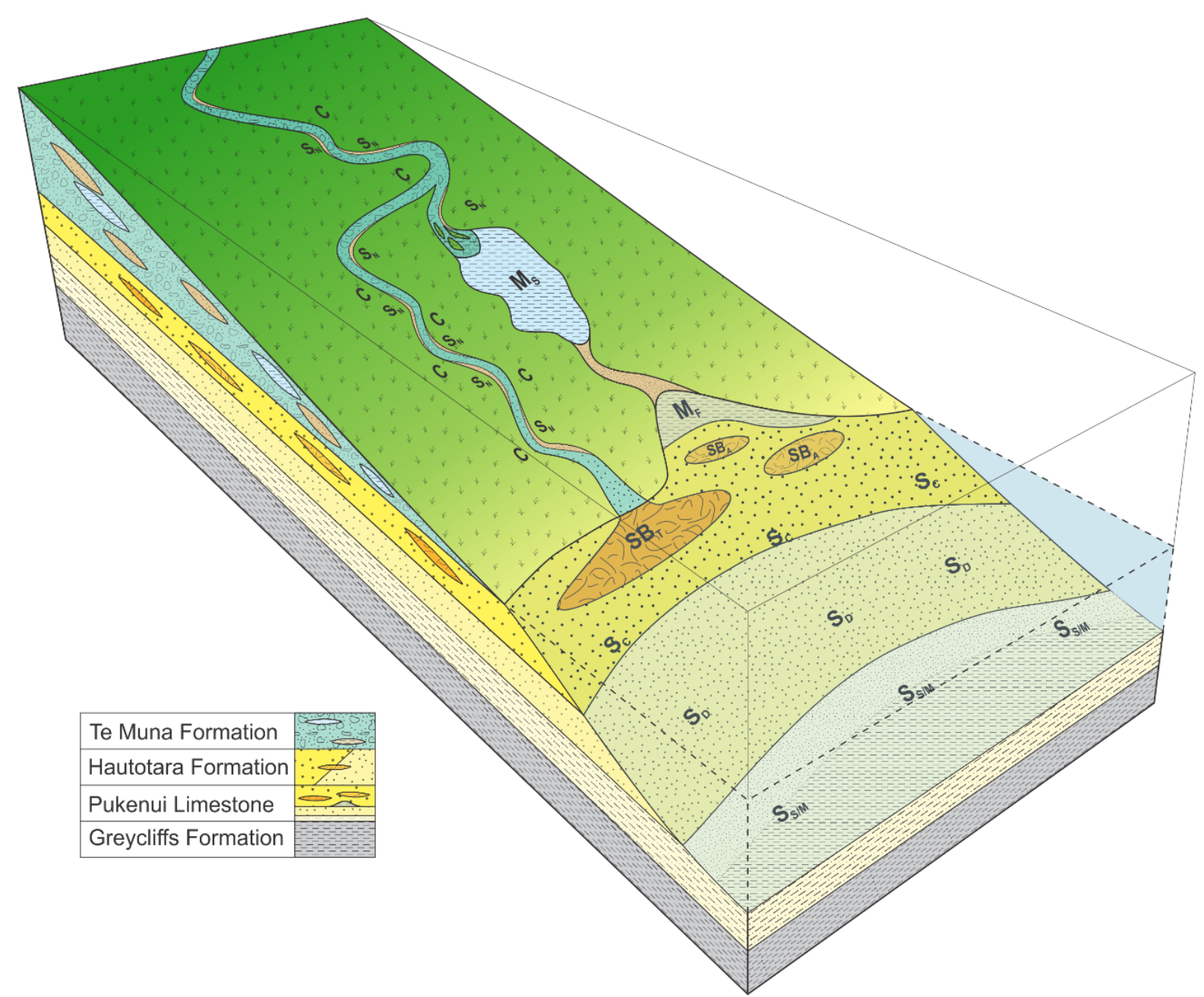

Figure 6.1: Schematic representation of facies recorded in the Hinakura and Longbush Road measured sections. Vertical and horizontal scales not true. 
Figure 6.2 shows how deposition may have occurred at six different times in the field area, specifically at the Hinakura Road measured section. Each section of Figure 6.2 corresponds to the deposition of a formation, from the Greycliffs Formation to the Te Muna Formation. Three sections (box 2, 3, \& 4) are used to represent the depositional environments of the Pukenui Limestone, and two (boxes $5 \& 6$ ) represent the Hautotara Formation. The vertical scale in Figure 6.2 is not to scale, as using true unit thickness, water depth, and highstand-lowstand fluctuations adds too much complexity. The ages shown in each box are approximate ages determined as a part of this study (Figure 6.3). The dark grey unit at the base of each box represents undifferentiated units older than the Greycliffs Formation. Its thickness increases to represent tectonic uplift.

Box 1 (Fig. 6.2) shows that during both highstand and lowstand conditions the depositional environment was deep enough to deposit a fine-grained muddy sandstone, depositing the Greycliffs Formation. Deposition occurred below storm wave base, and was deep enough that highstand/lowstand sea-level cycles are not recorded in such a way that they are easily observed in the field.

As time progressed and relative sea-level shallowed due to tectonic uplift and entered a lowstand period, conditions became favourable for the lowermost shellbeds of the Pukenui Limestone to deposit (Fig. 6.2, box 2). The low sea level was a result of a combination of cooler climate (lowstand) and tectonic uplift.

Box 3 (Fig. 6.2) shows that as relative sea level increases into a highstand period, shellbeds like those of Unit 2 (Fig. 6.2, box 2) were unable to form. Deposition was dominated by shoreface sandstone such as that seen in Units 3 and 4. Additional sealevel cycles are expected, however not observed at the Hinakura Road measured section, possibly due to the significant section of no-exposure between Units 3 and 4 .

The final deposition of the Pukenui Limestone occurred in very shallow conditions (Fig. 6.2, box 4), close to shore and proximal to river discharge. This is the shallowest Pukenui Limestone deposit, and the last fully marine deposition at this location.

The following sea level fluctuations between highstand and lowstand alternately exposed and flooded the sea floor (Fig. 6.2, box 5). The depositional environment was extremely shallow, beach face deposition, forming the marginal marine Hautotara Formation. 
Eventually tectonic uplift elevated the land high enough that sea-level during highstand periods was not high enough to flood the land surface, and all subsequent deposits were terrestrial (Fig. 6.2, box 7). These deposits formed the fluvial and lacustrine conglomerates, sandstones, and mudstones of the Te Muna Formation. Nowland (2011) showed that highstand-lowstand cycles during deposition of the Te Muna Formation caused the lake settings to move landward and shoreward respectively.

There are several issues raised by this model. These problems continue to be an issue, however solving them entirely is beyond the scope of the current study. Firstly is the issue of accommodation space. The lowest shellbeds of the Pukenui Limestone are considered to have been deposited above storm wave base during a lowstand period, in less than $10 \mathrm{~m}$ of water. Considering the range between lowstand and highstand sealevels is $\sim 60 \mathrm{~m}$ (Naish \& Wilson, 2009), together with a constantly uplifting basin, implies that there is less than $60 \mathrm{~m}$ of accommodation space available during a highstand. This means there not enough room to deposit the $82.55 \mathrm{~m}$ of sandstone and shellbeds of the Pukenui Limestone, even during a highstand period. Subsequent lowstand periods also need to be accounted for. These would lower relative sea-level to below the sea floor, suggesting terrestrial deposition. One way of overcoming this issue is to place significant unconformities within the Pukenui Limestone. These unconformities would need to remove any terrestrial deposition, as no terrestrial deposits were observed in the Pukenui Limestone at the Hinakura Road section. No indications of such unconformities were observed at the Hinakura or Longbush Road measured sections.

Secondly the sedimentation rate of the Pukenui Limestone and Hautotara Formation in the Hinakura Road section as measured in Section 6.9 (Pukenui Limestone, $67.66 \mathrm{~cm}$ $\mathrm{ky}^{-1}$, Hautotara Formation $19.3 \mathrm{~cm} \mathrm{ky}^{-1}$ ) seem unusually higher than expected. The sedimentation rates calculated here depend on the length of time over which the respective formation was deposited, and may be more apparent than real. They are likely the result of poor dating of the lithostratigraphic boundaries. Unfortunately, if the boundary dates were changed to add more time for deposition of the units, more sea level cycles would need to be present. Since they are not observed in the field area, additional unconformities that at the very least have removed an entire $40 \mathrm{kyr}$ sea-level cycle would need to be present. 


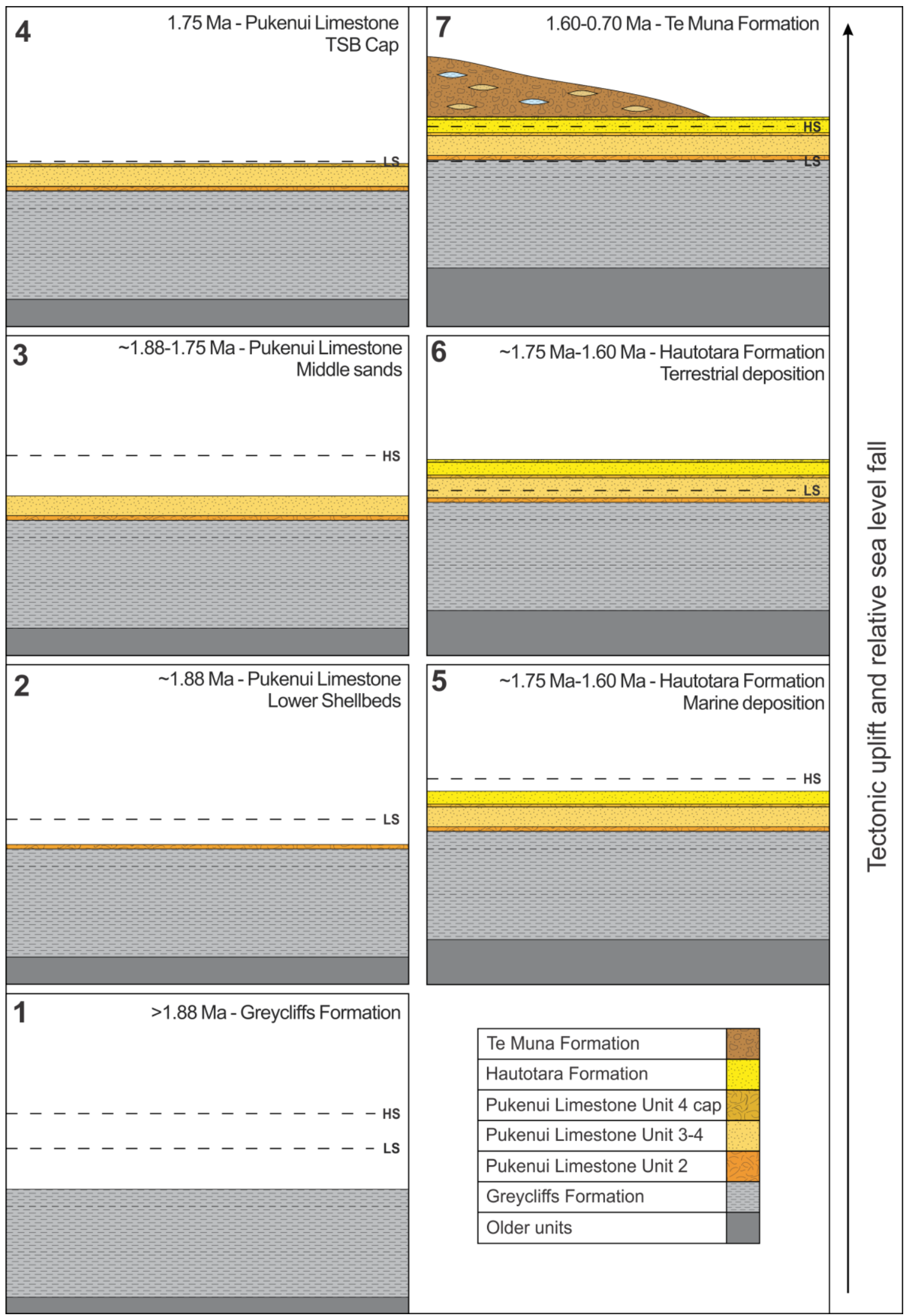

Figure 6.2: Deposition as it would have occurred at the Hinakura Road section, representing a relative sealevel fall due to tectonic uplift, and transition from fully marine (Greycliffs Formation) to fully terrestrial (Te Muna Formation) deposition. HS - Highstand, LS - Lowstand. Figure not to scale. 


\subsection{Stratigraphic correlations}

The majority of lithological horizons in the Hinakura road measured section cannot be correlated in detail with the type sections of the Pukenui Limestone, Hautotara Formation, and Te Muna Formation at the southern end of the Nga-Waka-A-Kupe Range. Here two boundaries are confidently correlated, and three with a lower level of confidence (Fig. 6.3)

The stratigraphically lowest shellbed observed in the field area is Unit 2. The lower contact of this unit in the Hinakura Road measured section marks the first appearance of Psychrochlamys delicatula in the section. This contact is confidently interpreted as being stratigraphically equivalent to the lower contact of Limestone A of the Pukenui Limestone (Fig. 6.3).

HR07 (overlying HR06) is included in the top part of Unit 2 as it contains a similar fauna to HR06 and the lower horizons of Unit 2, implying a lower water depth than the overlying fine sandstones and mudstones. The top of Unit 2 (HR06 and HR07) has two possible correlations with the type section. The first, based on the similarity of thickness of the two units, is that it is stratigraphically equivalent to the top of Limestone A. In terms of environment, the horizons within Unit 2 are all shallow water deposits, with the overlying Unit 3 indicating the first sign of significant sea-level deepening. This is comparable with the shallow water environment of the Limestone A and the relatively deeper A-B Interbed.

An alternative correlation is between HR06 and Limestone B, which would suggest that HR02 would a correlative of Limestone A. This is unlikely as the thicknesses do not correspond well. However, both correlations are low confidence. On the basis of the similarity of environments the former correlation is considered more likely.

The inference that the top of Unit 2 is likely to be equivalent to the top of Limestone A suggests that Unit 3 is equivalent, at least in part to the A-B Interbed. The mudstones and fine-grained sandstones of the facies within Unit 3 represent a deeper depositional environment than those found in Unit 2. This deepening is comparable to the change in environment determined when comparing the sediments of the Limestone A and the AB Interbed. Unit 3 is only compared to the lower section of the A-B Interbed as it is superseded by a significant section of no exposure at the Hinakura Road section. 
The majority of Unit 4 contains no horizons which are easily correlated with the type section. This is largely a result of the significant thickness of non-exposure that underlies Unit Four. Because the shellbed at the base of Unit 4 (HR17) is the only shellbed observed in this interval, and the fact it represents an interval of shallowing, it is possible that it is equivalent to Limestone B in the type section. However, this correlation is considered extremely speculative.

The Tawera Shellbed (HR26) of the Hinakura Road section is here considered to be stratigraphically equivalent to the hard, Tawera dominated cap at the top of the Limestone $\mathrm{C}$ in the type section (Fig. 6.1). Tawera subsulcata are not unique to this horizon, however, they are rarely found dominating a bed to the extent seen at the very top of the Pukenui Limestone. HR 26 is very similar in terms of cementation and colour to the top of the Pukenui limestone in the type section. This correlation carries with it a high degree of confidence. Centimetre scale, matrix-dominated Tawera beds at the Longbush Road section have been correlated with the C cap of the Pukenui Limestone. It is possible that the HR26 shellbed is equivalent to the entire Limestone C. However the significant difference in stratigraphic thickness suggests that this correlation carries an extremely low level of confidence.

The friable sandstones of Unit 5 overlying the Tawera bed are almost certainly equivalent to the Hautotara Formation (Fig. 6.1). This is supported by the presence of Zethalia zelandica in sediments from immediately above the Tawera shellbed. Although the lower contact of the Hautotara formation in the Hinakura road section can be identified with a high degree of certainty, the placement of the upper contact is much more problematic.

The conglomerates of horizon HR36 at the base of Unit 6 are fully terrestrial and considered to be equivalent with the lowermost Te Muna Formation. This suggests that the Hautotara Formation/Te Muna boundary lies somewhere in the three meter section of non-exposure that occurs between Units 5 and 6 .

Figure 6.1 demonstrates the significant thickness change of the Hautotara Formation between the type section and the Popes Head area. The thickness of the Hautotara Formation is known to vary significantly along the range and is thought to be due to changes in accommodation space resulting from the formation of the of anticline and 
syncline structures which began forming during deposition of the underlying units (Rampton, 1997). Using seismic data, Cape et al. (1990) identified $35 \mathrm{~m}$ of Hautotara Formation near the type section, and $>100 \mathrm{~m}$ in the northwest of the Huangarua Syncline. The formation is expected to be thinner on the flank of the Windy Peak Anticline and thicker near the axis of the Huangarua syncline, due to differences in water depth as a result of the relevant structures. The Ruawaka Section described by Nowland (2011) is likely to represent shallower facies than the original Hautotara Formation type section. This is due to its location on the flank of the Windy Peak Anticline/Monocline, which would have formed a topographic high and therefore shallower water depths. The limestone identified by Nowland (2011) in the Ruawaka Section is interpreted as being stratigraphically equivalent with the D Limestone of Rodley (1961), the lowest cemented member of the Hautotara Formation. The lack of successive coquina or cemented members in the Ruawaka section can be attributed to the shallowing of the area due to the growth of the Windy Peak Anticline.

As noted above, the terrestrial conglomerates, mudstones, and sandstones of Unit 6 (HR36 to HR45) can be confidently correlated with the lowest horizons of the Te Muna formation (Fig. 6.3). Sediments recorded in Unit 6 are fully terrestrial, consisting of fluvial and lacustrine facies, which are only found in the Te Muna and younger sediments. The two tephras (Hinakura Road Upper and Lower Tephra) provide an age of 1.6 Myr, making the lower contact of the Te Muna Formation at Hinakura Road $\sim 200,000$ years older than at the type section. This is significantly older when compared to the oldest tephra of the type area. This supports an earlier shallowing of the study area compared to the type section area.

An important aspect of comparison between the type section and the Hinakura Area is the obvious lithological evidence for sea-level cycles. Such cycles are obvious in the field at the type section, but not at either the Hinakura or Longbush Road sections. The type section includes five members, which represent three low sea level coquinas interbedded with two high sea-level sandstone and mudstone interbeds. However, previous observations from further north near Gladstone (Beu, 1995) suggested that the cycles within the Pukenui Limestone are less obvious everywhere but at the type section. This is important for the correlation between the Hinakura Area sections and the type section, and whether or not 'equivalent' members can be seen. While not as 
obvious in the field such as in the form of clear coquina members, the lithology and fauna of the Pukenui Limestone should still represent a sea-level change, regardless of where observations are taking place. 


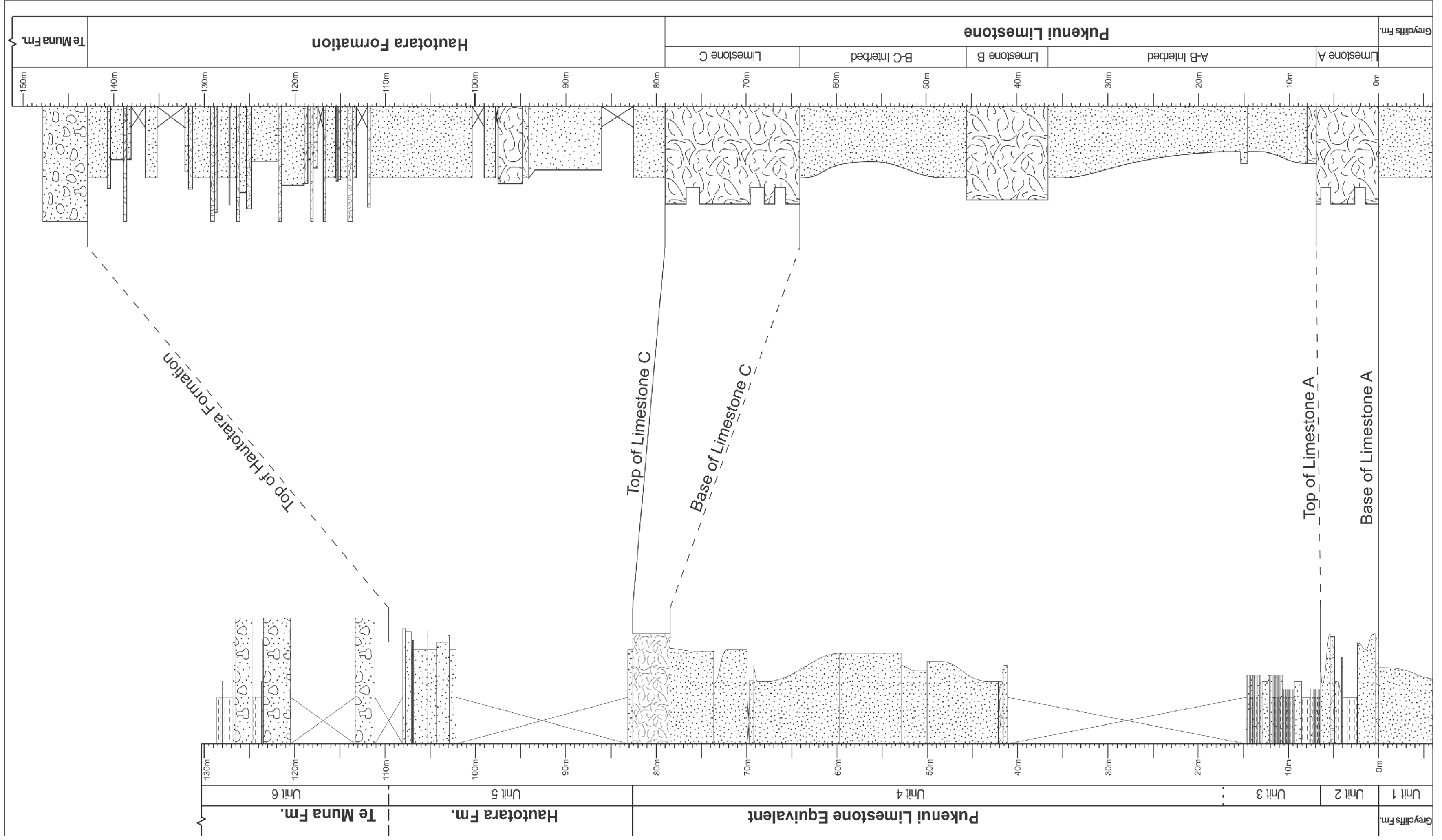

Figure 6.3: Diagram showing correlations made between the Hinakura Road measured section (left column) and the type section for the Pukenui Limestone and Hautotara Formation (right column). Solid lines represent confident correlations, while dashed lines represent low confidence correlations. 


\subsection{Controls on carbonate accumulation}

Limestone facies typically occur in tectonically quiescent areas as carbonate sediment deposition is inversely related to terrigenous sedimentation rates (Kamp \& Nelson, 1988). On forearc shelves, where terrigenous deposition is $\sim 100 \mathrm{~cm} \mathrm{kyr}^{-1}$, carbonate cover is $1-3 \%$ (Kamp \& Nelson, 1987).

During the late Pliocene and early Pleistocene, glacio-eustatically induced sea-level movements combined with tectonism to form widespread limestones during the glacial episodes in eastern North Island (Kamp \& Nelson, 1988). During glacial periods sea level is lower and terrigenous sediment supply is reduced, creating favourable conditions for carbonate to deposit. During highstand periods, sea level and terrigenous sediment supply increases as a result of climatic warming. The result of climatic warming is an acceleration of the hydrological cycle, which leads to intensified chemical and physical erosion, and therefore an increase in discharge of terrigenous material from rivers (Slotnick et al., 2012). Increased sediment content in the ocean inhibits carbonate deposition and suppresses shellbed development (Dunbar, personal communications, 2019).

\subsection{Driver 1 - Landward shallowing}

While stratigraphically equivalent to the Pukenui Limestone and Hautotara Formation type sections, the units in the measured sections at Hinakura and Longbush Road represent deposition closer to shore than those at the type section. Sea-level cycles and changes in water depth recorded in the type section are evident at the Popes Head area, however the sections included here reflect relatively shallower water depth.

The sandstone underlying HR02 (Section 4.2.1, Fig. 4.1 C) correlated to the Greycliffs Formation is coarser and more friable than that found underlying the Pukenui Limestone at the type locality, representing deposition in a shallower marine setting.

Unit 2 is stratigraphically equivalent to the A Limestone of the Pukenui Limestone. HR02 and HR06 (including the overlying well-cemented sandstone, HR07) represent the lower and upper contacts of the member. The two shellbeds within Unit 2 (HR2 \& HR6, Enclosure A) contain fauna that indicates deposition in a marine environment shallower than the subtidal environment represented by fauna found in the type section. 
Austrovenus stutchburyi and Ruditapes largillierti are both estuarine and enclosed bay restricted species, while Dosinia subrosea lives in low tide environments off sandy beaches (Beu \& Raine, 2009). Psychrochlamys delicatula has been identified as a deep water species in modern studies, however there is evidence that their environment is not determined by depth but by water temperature (Atkins, 1995).

The presence of indurated sandstone clasts throughout both sections is an indication that deposition was influenced by a river able to transport material out of the nearby Aorangi Range. Clasts in coquina beds of the Pukenui Limestone throughout the type locality and at Taylors Bridge on Longbush Road were interpreted by Nowland (2011) to have been deposited by rivers. The large clast size $(\sim 5 \mathrm{~cm})$ supports this. The Aorangi Range to the south is the most obvious structural high in the area, composed of emerging indurated sandstone (Begg \& Johnston, 2000). Rivers draining the Aorangi Range were responsible for transporting the clasts, depositing them at the coast where they were reworked into the shoreface zone (Nowland, 2011). The north flow direction determined from the overlying Te Muna Formation at the Hinakura and Longbush Road sections supports this.

\subsubsection{Sea-level changes}

The relationship between glacio-eustatic sea-level change and tectonics, and how they control the deposition of the formations under study is shown in Figure 6.4 and Figure 6.5. Figure 6.4 represents deposition in the type section area, while Figure 6.5 represents deposition in the area covered in this study.

Figure 6.5 shows that in the northern area of the Nga-Waka-A-Kupe Range, tectonic uplift occurred earlier than in the type locality, lowering relative sea level and depositing shallower facies earlier. This has an impact on deposition, as each high- and lowstand is shallower than at the type locality. The figure represents fully marine deposition of the Pukenui Limestone (shaded) as sea level does not fall below the black line. During the deposition of the Hautotara Formation, sea-level continued to rise, and the rise and fall of sea-level lead to alternating sub-aerial and sub-marine depositional conditions. Eventually, the land had risen high enough that sea-level could not overcome it, and only terrestrial deposition was recorded, resulting in the Te Muna Formation. The age of the lowest tephra in the Te Muna Formation at the Hinakura 
Road section is $1.6 \mathrm{Myr}$ old, $\sim 0.2 \mathrm{Myr}$ older than the Te Muna Formation base at the type locality. This indicates that emergence happened 200,000 years earlier.

\subsubsection{Cyclostratigraphy}

Unconformities are expected at sequence boundaries where shallow water environments erode sediment deposited during falling stage system tracts. Unconformities were rarely observed throughout the exposure along both measured sections. Lack of good exposure in parts may explain several missing unconformities; however, several sequence boundaries are present without the clear presence of an unconformity. It is inferred that at these unconformities, depositional setting was the same before and after erosion (or lack of deposition). This would leave the same lithology and, in this case, the same macrofauna throughout both units, making the unconformity boundaries impossible to identify.

Unit 4 is a $41.5 \mathrm{~m}$ thick sequence of sandstones, most of which are similar in texture and macrofauna. This unit is an example of where a sequence boundary may be hidden within the units, undetectable in outcrop due to the nature of the sediments either side of the boundary. Other methods of analysis may reveal a change such as microfauna or pXRF scanning. 


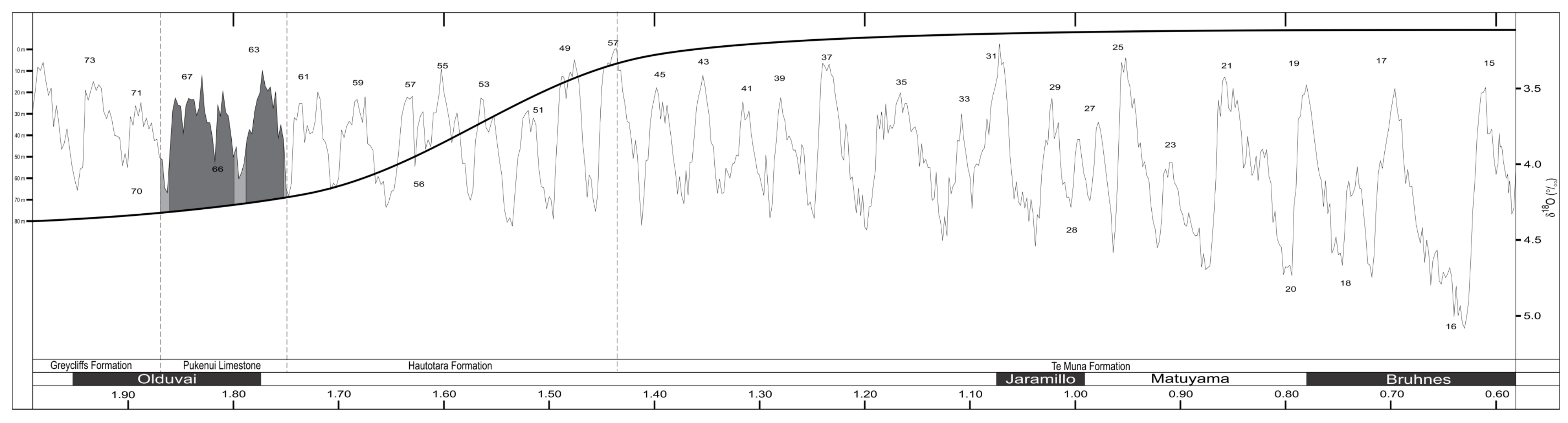

Figure 6.4: Diagram representing deposition related to sea-level and tectonics at the type locality for the Pukenui Limestone, Hautotara Formation, and Te Muna Formation. Black line represents tectonic uplift. Light shading indicates Pukenui Limestone coquina member deposition, and dark shading represents interbed deposition. Sea level column present only as a guide to quantify sea level changes. Modified from Anderson-Scott (2017), sea level curve from Lisiecki \& Raymo (2005), sea-level amplitudes from Naish \& Wilson (2009)

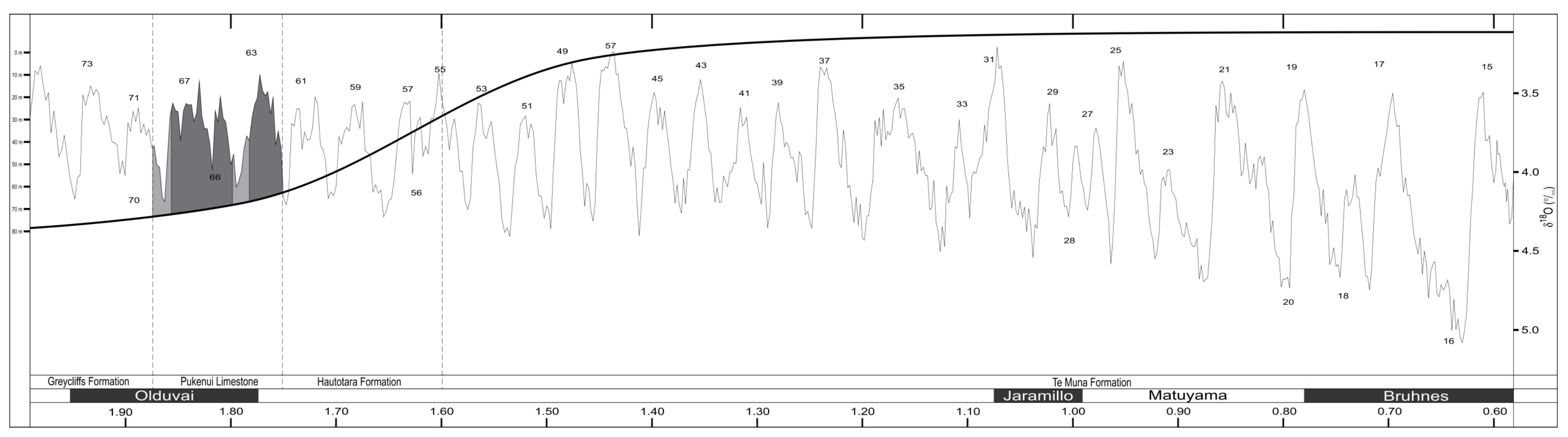

Figure 6.5: Diagram representing deposition related to sea level and tectonics at the Popes Head area for the Pukenui Limestone, Hautotara Formation, and Te Muna Formation. Black line represents tectonic uplift. Light shading indicates Pukenui Limestone coquina member deposition, and dark shading represents interbed deposition. Sea level column present only as a guide to quantify sea level changes. Modified from Anderson-Scott (2017), sea level curve from Lisiecki \& Raymo (2005), sea-level amplitudes from Naish \& Wilson (2009) 


\subsection{Driver 2 - Sediment supply}

The presence of millimetre to centimetre scale clasts within many of the units in both sections at the Popes Head area is an indication that there was enough energy near the site of deposition to transport them. This supports deposition more proximal to land, and influenced by discharge from a river.

Austrovenus stutchburyi, Limnoperna huttoni, and Ruditapes largillierti are common throughout many of the horizons recorded in this study. Austrovenus stutchburyi and Ruditapes largillierti live in enclosed bays with salinity slightly lower than the open ocean, preferring estuarine environments. Limnoperna huttoni is restricted to estuarine environments. If in situ, then these species support the influence of a river on deposition.

The differences in facies may then be due to a change in the sediment supply and the increased input of freshwater from local rivers, which has inhibited carbonate formation. The lack of carbonate deposition causes the Pukenui Limestone and Hautotara Formation to appear more uniform, without the obvious coquina members that are observed in the respective type sections.

\subsection{Combined drivers}

There is evidence throughout the two sections that suggest that both drivers, landward shallowing and sediment supply are responsible for the difference in facies between Popes Head and the type section. Accurately determining how much of each controlling factor played a part relative to the other is not clear, however there are observations suggesting further studies may make obvious the relative contribution of each factor.

An increase in clast number and size upwards through the section indicates that discharge from rivers was beginning to have a greater effect on the facies recorded. This would suggest that the older units were more susceptible to sea-level change while the younger units were more affected by proximity to land. The lithology change observed in the Greycliffs Formation along Hinakura Road at the base of the section is evidence of the susceptibility to sea-level change, as the most obvious difference to the type section was in increase in grainsize. 
Despite being deposited in a shallower environment that the respective type sections, the lower units at the Hinakura Road measured section were deposited in an environment deep enough that proximity to land did not have much of an effect. As the environment shallowed, and the shore prograded, deposition at the Hinakura Road section began to be influenced more by river discharge as it was closer.

\subsection{Age of deposition}

The age of each unit included in this study has been modified by many studies in the past (Vella \& Briggs, 1971; Collen \& Vella, 1984; Gammon, 1995; Nicol et al., 2002; Nowland, 2011), depending on the method used. While this study has not found any new evidence to further constrain the age beyond what has previously been accomplished, a new interpretation is provided. This interpretation is based on the oxygen isotope curve which is a proxy for temperature and sea-level produced by Lisiecki and Raymo (2005), and Figure 13 from Anderson-Scott (2017; pp 39). Figure 6.4 shows a new interpretation of the figure from Anderson-Scott (2017), which represents the type area near the southern end of the Nga-Waka-A-Kupe Range. Figure 6.5 is the same figure adapted to the area for this study, at the Popes Head area.

The deposition of the Pukenui Limestone at the Popes Head area is interpreted as being between $1.87 \mathrm{Ma}$ and 1.75 Ma, a total time of 120,000 years. This is in agreeance with previous studies that determined the Pukenui Limestone as being deposited over the course of three 40,000-year sea-level cycles. The Hautotara Formation is interpreted as being deposited between 1.75 Ma and 1.60 Ma. This is equal to 150,000 years, and approximately four 40,000-year sea-level cycles.

\subsection{Sedimentation rate}

The sedimentation rates for the Pukenui Limestone and Hautotara Formation at Hinakura Road were calculated as $71.8 \mathrm{~cm} / \mathrm{kyr}$ and $18 \mathrm{~cm} / \mathrm{kyr}$ respectively. These are net values, calculated using the overall thickness of each unit and the contact dates determined in this study.

Calculation of the sedimentation rates here is based on several assumptions, the most important being the time of deposition. For that, the age of the lower and upper contacts need to be known. As there are no precise dates for either the Pukenui Limestone or 
Hautotara Formation, the length of time over which they were deposited needs to be approximated. For the Pukenui Limestone, this is considered three $40 \mathrm{kyr}$ orbital cycles, equalling 120,000 years. For the Hautotara Formation, this is considered approximately three and a half $40 \mathrm{kyr}$ orbital cycles, equalling 150,000 years. These numbers were determined from Figure 6.5, which shows how many 40 kyr cycles are recorded within each formation.

Kennett, Watkins and Vella (1971) determined a sedimentation rate of $40 \mathrm{~cm} \mathrm{ky}^{-1}$ for the Greycliffs Formation and underlying Mangaopari Mudstone. Nelson (1978) calculated sedimentation rates for carbonate sediments in New Zealand as $<5 \mathrm{~cm} \mathrm{ky}^{-1}$. Kamp and Nelson (1987) indicate that terrigenous sediment supply on forearc shelves can reach $100 \mathrm{~cm} \mathrm{ky}^{-1}$. These values indicate that the sedimentation rate calculated for the Pukenui Limestone and Hautotara Formation at Hinakura Road are within reason. 


\section{Chapter Seven \\ Conclusion}

\subsection{Major findings}

This study has built off previous studies in the southern Wairarapa to answer several questions outlined in Chapter One. The main goal was to determine whether facies changes were a result of environment change or sediment supply.

The aim of this study was to determine what change in depositional environment has occurred between the Pukenui Limestone and Hautotara Formation at their type sections and at Popes Head (Section 1.2).

- The lithostratigraphy and macropaleontology were documented in detail at two measured section at Popes Head. The 133 m Hinakura Road section was divided into 6 units comprising 45 horizons, and included the entire Pukenui Limestone and Hautotara Formation. The 29.75 m Longbush Road measured section was divided into 3 units comprising 10 horizons, and included the upper Pukenui Limestone to lower Te Muna Formation. The Longbush Road section was problematic as it was found to repeat itself and therefore was of limited value, leaving the majority of this work to rely on the Hinakura Road section.

- A facies analysis was carried out by using the lithological and paleontological data, compared to literature, which characterised ten lithofacies. From the facies a range of paleoenvironments were determined, from shoreface shelly sandstone to terrestrial conglomerates. The section is dominantly shallow marine, proximal to a river discharge.

- The results were compared to the previously documented Pukenui Limestone and Hautotara Formation type sections. The type sections contain deeper water sediments than were found at the study area, and present clear cycles of sedimentation. This study concluded that the strata recorded at both measured 
sections in the Popes Head area were deposited in shallower depositional environments than in the respective type sections, and that both the sea level and sediment supply had an effect on facies. The outcome has shown that both sea level shallowing and sediment supply are contributing factors to the observed facies change, and that the two processes are related

The age of the Pukenui Limestone and Hautotara Formation contacts have not been constrained more than in previous studies, however revisions have been attempted by matching deposition with a global sea-level cycle. The Pukenui Limestone was determined as being deposited between 1.87 and $1.75 \mathrm{Ma}$, and the Hautotara Formation between 1.75 and $1.60 \mathrm{Ma}$.

\subsection{Future Work}

Additional similar studies on the Pukenui Limestone and Hautotara Formation covering a wider geographical area are necessary to determine how the depositional setting for the units has changed throughout the basin, the extent of the change, and what its causes were. Facies analysis on stratigraphically equivalent sediments in other areas is necessary to reconstruct detailed paleoenvironments. These studies would supplement others such as Dobbie (1982) and Beu (1995), which documented the Pukenui Limestone as incredibly variable throughout the Wairarapa, and do not record the same obvious cycles that are seen at the type section. This may reveal that the Pukenui Limestone is unusual at the type section, and that sections such as the Hinakura Road section are typical.

More work is needed to determine the extent to which deposition is impacted by sealevel shallowing due to tectonics versus proximity to a river discharge. In essence, has environment change or sediment supply had a greater effect on the deposition of PlioPleistocene sediments in the Wairarapa.

The accommodation space issue requires solving to properly explain how deposition of the Pukenui Limestone and Hautotara Formation has occurred during emergence of the local basin. Further studies need to be taken to refine the age of the Pukenui Limestone contacts. Strontium dating has the potential to provide more accurate and precise ages. 


\section{References}

Allan, A. S. R., Baker, J. A., Carter, L., \& Wysoczanksi, R. J. (2008). Reconstructing the Quaternary evolution of the world's most active silicic volcanic system: insights from an $\sim 1.65 \mathrm{Ma}$ deep ocean tephra record sourced from Taupo Volcanic Zone, New Zealand. Quaternary Science Reviews, 27(25-26), 23412360. doi:10.1016/j.quascirev.2008.09.003

Anderson-Scott, F. (2017). Geological field mapping of Plio-Pleistocene strata in the Te Muna Area, Wairarapa, New Zealand. (Unpublished B.Sc. Honours thesis), Victoria University of Wellington.

Andrews, K. (2001). The depositional environment of the Pukenui Limestone, in the Hinakura Road area, Southern Wairarapa, New Zealand (Unpublished B.Sc. Honours thesis), Victoria University of Wellington.

Atkins, C. (1995). The depositional environment of the Pukenui "A" Limestone, Wairarapa, New Zealand. (Unpublished B.Sc. Honours thesis), Victoria University of Wellington.

Atkins, C., \& Collins, K. (2015). Pleistocene cyclic stratigraphy, South Wairarapa, New Zealand. Field Guides Geosciences 2015, Wellington, Geosciences Society of New Zealand Miscellaneous Publication 143b.

Begg, J. G., \& Johnston, M. R. (2000). Geology of the Wellington area. Institute of Geological and Nuclear Sciences Limited.

Beu, A. G. (1995). Pliocene limestones and their scallops: lithostratigraphy, pectinid biostratigraphy, and paleogeography of eastern North Island late Neogene limestone: Institute of Geological \& Nuclear Sciences Limited.

Beu, A. G. (2010). Marine Mollusca of isotope stages of the last 2 million years in New Zealand. Part 3. Gastropoda (Vetigastropoda - Littorinimorpha). Journal of the Royal Society of New Zealand, 40(3-4), 59-180.

doi:10.1080/03036758.2010.500717

Beu, A. G., \& Raine, J. I. (Eds.). (2009). Revised descriptions of New Zealand Cenozoic Mollusca from Beu and Maxwell (1990).

Beu, A. G. a. M. P. A. (1990). Cenozoic Mollusca of New Zealand.

Boggs, S. (2006). Principles of sedimentology and stratigraphy.

Browne, G. H., \& Naish, T. R. (2003). Facies development and sequence architecture of a late Quaternary fluvial-marine transition, Canterbury Plains and shelf, New Zealand: implications for forced regressive deposits. Sedimentary Geology, 158(1-2), 57-86. doi:10.1016/s0037-0738(02)00258-0

Cape, C. D., Lamb, S. H., Vella, P., Wells, P. E., \& Woodward, D. J. (1990). Geological structure of Wairarapa Valley, New Zealand, from seismic reflection profiling. Journal of the Royal Society of New Zealand, 20(1), 85-105. doi:10.1080/03036758.1990.10426734 
Clarke, D. (1998). A Biostratigraphic Investigation of the Pukenui Limestone Formation, South Wairarapa, New Zealand. (Unpublished M.Sc. thesis), Victoria University of Wellington.

Cole, R. G., Hull, P. J., \& Healy, T. R. (2000). Assemblage structure, spatial patterns, recruitment, and post-settlement mortality of subtidal bivalve molluscs in a large harbour in north-eastern New Zealand. New Zealand Journal of Marine and Freshwater Research, 34(2), 317-329. doi:10.1080/00288330.2000.9516935

Collen, J. D., \& Vella, P. (1984). Hautotara, Te Muna and Ahiaruhe Formations, middle to late Pleistocene, Wairarapa, New Zealand. Journal of the Royal Society of New Zealand, 14(4), 297-317. doi:10.1080/03036758.1984.10421732

Couper, R. (1948). The Geology of the Makara and Ruakokopatuna Valleys, East Wairarapa. (Unpublished M.Sc. thesis), Victoria University College.

Crawford, J. (1861). Report on a geological tour in the Wairarapa and East Coast country. New Zealand Govemment Gazette (Province of Wellington), 8(35), 239242.

Dobbie, W. A. (1982). Sedimentology and Diagenesis of the Pukenui Limestone Formation, Wairarapa, New Zealand. (Unpublished M.Sc. thesis), Victoria University of Wellington.

Edwards, A. R. (1987). An integrated biostratigraphy, magnetostratigraphy and oxygen isotope stratigraphy for the late Neogene of New Zealand (Vol. 23): New Zealand Geological Survey, Dept. of Scientific and Industrial Research.

Ellis, J., Cummings, V., Hewitt, J., Thrush, S., \& Norkko, A. (2002). Determining effects of suspended sediment on condition of a suspension feeding bivalve (Atrina zelandica): results of a survey, a laboratory experiment and a field transplant experiment. Journal of Experimental Marine Biology and Ecology, 267(2), 147-174. doi:Doi 10.1016/S0022-0981(01)00355-0

Gammon, P. (1995). Hautotara Formation, Mangaopari Basin, New Zealand: Record of a cyclothemic Pliocene-Pleistocene marine to nonmarine transition. New Zealand Journal of Geology and Geophysics, 38(4), 471-481. doi:10.1080/00288306.1995.9514672

Gammon, P. R. (1997). Sequence stratigraphy of the Mangaopari Basin, southeastern North Island, New Zealand. (Unpublished Ph.D thesis), James Cook University.

Hayward, B. W., Grace, R. V., \& Francis, M. P. (1986). Sediments and benthos of northeastern Great Barrier Island, New Zealand. Journal of the Royal Society of New Zealand, 16(4), 347-355. doi:10.1080/03036758.1986.10416813

Hector, J. (1884). Progress report, 1884. Retrieved from

Hendy, A. J. W., \& Kamp, P. J. J. (2004). Late Miocene to early Pliocene biofacies of Wanganui and Taranaki Basins, New Zealand: Applications to paleoenvironmental and sequence stratigraphic analysis. New Zealand Journal of Geology and Geophysics, 47(4), 769-785. doi:10.1080/00288306.2004.9515088

Hilgen, F. J., Lourens, L. J., Van Dam, J. A., Beu, A. G., Boyes, A. F., Cooper, R. A., . . .Wilson, D. S. (2012). The Neogene Period The Geologic Time Scale (pp. 923978). 
Jackson, J. A. (2005). Glossary of geology. Glossary of Geology, by JA Jackson. 2005 5th revised ed. ISBN 3-540-27951-2. Berlin: Springer, 2005., 5th.

Kamp, P. J., \& Nelson, C. S. (1987). Tectonic and sea-level controls on nontropical Neogene limestones in New Zealand. Geology, 15(7), 610-613.

Kamp, P. J. J., \& Nelson, C. S. (1988). Nature and occurrence of modern and Neogene active margin limestones in New Zealand. New Zealand Journal of Geology and Geophysics, 31(1), 1-20. doi:10.1080/00288306.1988.10417807

Kennett, J. P., Watkins, N., \& Vella, P. (1971). Paleomagnetic chronology of Plioceneearly Pleistocene climates and the Plio-Pleistocene boundary in New Zealand. Science, 171(3968), 276-279.

King, L. (1933). Tertiary molluscan faunas from the southern Wairarapa. Paper presented at the Transactions of the New Zealand Institute.

Lamb, S., \& Vella, P. (1987). The last million years of deformation in part of the New Zealand plate-boundary zone. Journal of structural geology, 9(7), 877-891.

Lee, J. M., \& Begg, J. (2002). Geology of the Wairarapa area: Institute of Geological \& Nuclear Sciences.

Lisiecki, L. E., \& Raymo, M. E. (2005). A Pliocene-Pleistocene stack of 57 globally distributed benthic $\delta 180$ records. Paleoceanography, 20(1), n/a-n/a. doi:10.1029/2004pa001071

Little, T., Van Dissen, R., Schermer, E., \& Carne, R. (2009). Late Holocene surface ruptures on the southern Wairarapa fault, New Zealand: Link between earthquakes and the uplifting of beach ridges on a rocky coast. Lithosphere, $1(1), 4-28$

McKay, A. (1877). Report on the country between Masterton and Napier. Rep. Geol. Explor. during 1876, 77, 07-94.

Mckay, A. (1878). Report on East Wairarapa District. N.Z. Geological Survey Reports of Geological Explorations 1877-78, 11, 14-24.

Mckay, A. (1879). The southern part of the East Wairarapa District. N.Z. Geological Survey Reports of Geological Explorations 1878-79, 12, 75-86.

McKnight, D. G. (1969). Infaunal benthic communities of the New Zealand continental shelf. New Zealand Journal of Marine and Freshwater Research, 3(3), 409-444. doi:10.1080/00288330.1969.9515308

Naish, T. R., \& Wilson, G. S. (2009). Constraints on the amplitude of Mid-Pliocene (3.6-2.4Ma) eustatic sea-level fluctuations from the New Zealand shallowmarine sediment record. Philos Trans A Math Phys Eng Sci, 367(1886), 169187. doi:10.1098/rsta.2008.0223

Neef, G. (1970). Notes on the Subgenus Pelicaria. New Zealand Journal of Geology and Geophysics, 13(2), 436-476. doi:10.1080/00288306.1970.10423978

Nelson, C. S. (1978). Temperate Shelf Carbonate Sediments in the Cenozoic of NewZealand. Sedimentology, 25(6), 737-771. doi:DOI 10.1111/j.13653091.1978.tb00328.x

Nicol, A., VanDissen, R., Vella, P., Alloway, B., \& Melhuish, A. (2002). Growth of contractional structures during the last $10 \mathrm{~m} . \mathrm{y}$. at the southern end of the 
emergent Hikurangi forearc basin, New Zealand. New Zealand Journal of

Geology and Geophysics, 45(3), 365-385. doi:10.1080/00288306.2002.9514979

Nowland, S. W. (2011). The Early Quaternary Marine to Terrestrial Transition of the Southeastern Wairarapa, New Zealand. (Unpublished M.Sc. thesis), Victoria University of Wellington.

Orpin, A., Gammon, P., Naish, T., \& Carter, R. (1998). Modern and ancient Zygochlamys delicatula shellbeds in New Zealand, and their sequence stratigraphic implications. Sedimentary Geology, 122(1-4), 267-284.

Pillans, B., Kohn, B. P., Berger, G., Froggatt, P., Duller, G., Alloway, B., \& Hesse, P. (1996). Multi-method dating comparison for mid-Pleistocene Rangitawa tephra, New Zealand. Quaternary Science Reviews, 15(7), 641-653.

Rampton, J. (1997). The Stratigraphy and Geologic History of the Late Neogene Sequence Within the Ngarara Stream-Huangarua River Region, Southeastern Wairarapa, New Zealand. (Unpublished M.Sc. thesis), Victoria University of Wellington.

Rataul, M. (1988). Sedimentology of Hautotara and Te Muna formations, Wairarapa, New Zealand. (Unpublished M.Sc. thesis), Victoria University of Wellington.

Rodley, D. R. (1961). The Geology and Paleoecology of Nukumaruan Strata Near the Junction of Ruakokopatuna and Makara Rivers. (Unpublished M.Sc. thesis), Victoria University of Wellington.

Sam Boggs , J. (2006). Principles of sedimentology and stratigraphy (Fourth Edition ed.). Upper Saddle River, N.J: Pearson Education, Inc.

Shane, P., \& Froggatt, P. (1991). Glass chemistry, paleomagnetism, and correlation of middle Pleistocene tuffs in southern North Island, New Zealand, and Western Pacific. New Zealand Journal of Geology and Geophysics, 34(2), 203-211.

Shane, P. A. R. (1990). Correlation of some Pliocene tuffs in Southern Wairarapa, New Zealand, and comparison with biostratigraphic and magnetostratigraphic data. New Zealand Journal of Geology and Geophysics, 33(2), 349-354. doi:10.1080/00288306.1990.10425692

Shane, P. A. R., Black, T. M., Alloway, B. V., \& Westgate, J. A. (1996). Early to middle Pleistocene tephrochronology of North Island, New Zealand: Implications for volcanism, tectonism, and paleoenvironments. Geological Society of America Bulletin, 108(8), 915-925. doi:Doi 10.1130/00167606(1996)108<0915:Etmpto>2.3.Co;2

Slotnick, B. S., Dickens, G. R., Nicolo, M. J., Hollis, C. J., Crampton, J. S., Zachos, J. C., \& Sluijs, A. (2012). Large-Amplitude Variations in Carbon Cycling and Terrestrial Weathering during the Latest Paleocene and Earliest Eocene: The Record at Mead Stream, New Zealand. The Journal of Geology, 120(5), 487505. doi:10.1086/666743

Thomson, J. A. (1919). Geological and Palaeontological notes on the Palliser Bay District. New Zealand Journal of Science \& Technology, 2, 6-7.

Trewick, S. A., \& Bland, K. J. (2012). Fire and slice: palaeogeography for biogeography at New Zealand's North Island/South Island juncture. Journal of the Royal Society of New Zealand, 42(3), 153-183.

doi:10.1080/03036758.2010.549493 
Vella, P. (1949). The geology of an area south-east of Martinborough. (Unpublished M.Sc. thesis), Victoria University College, Wellington.

Vella, P. (1953). The genus Pelicaria in the Tertiary of east Wairarapa. Paper presented at the Transactions of the Royal Society of New Zealand.

Vella, P. (1954). Tertiary Mollusca from south-east Wairarapa. Paper presented at the Transactions of the Royal Society of New Zealand.

Vella, P. (1963). Plio-Pleistocene Cyclothenes, Wairarapa, New Zealand.

Vella, P., \& Briggs, W. M. (1971). Lithostratigraphic Names, Upper Miocene to Lower Pleistocene, Northern Aorangi Range, Wairarapa. New Zealand Journal of Geology and Geophysics, 14(2), 253-\&.

Waghorn, R. (1927). The geology of the Ruakokopatuna Valley, southern Wairarapa. Paper presented at the Transactions and Proceedings of the New Zealand Institute.

Walker, R. G., \& James, N. P. (1992). Facies models: response to sea level change: St. John's, Nfld.: Geological Association of Canada= Association géologique ....

Woolfe, K. J. (1993). Lakes Onoke and Wairarapa as modern analogues for the Hautotara and Te Muna formations (mid-Pleistocene), southern Wairarapa, New Zealand. Sedimentary Geology, 84(1-4), 123-137. 



\section{Appendices}




\section{Appendix One \\ Measured Sections}

Hinakura Road measured section - see Enclosure A

Longbush Road measured section - see Enclosure B

\begin{tabular}{|c|c|c|c|c|c|}
\hline \multicolumn{2}{|c|}{ Lithology } & \multicolumn{2}{|c|}{ Paleontology Symbols } & \multicolumn{2}{|c|}{ Sedimentary Symbols } \\
\hline Mudstone & 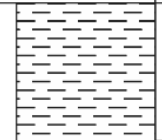 & $\begin{array}{l}\text { Bivalves } \\
\text {-broken }\end{array}$ & $\begin{array}{l}\mathbb{E} \\
\mathbb{E}\end{array}$ & Bedding & $\bar{\equiv}$ \\
\hline Sandstone & & $\begin{array}{c}\text { Gastropods } \\
\text {-broken }\end{array}$ & $\begin{array}{l}\text { 息 } \\
\text { 急 }\end{array}$ & Concretions & $\Theta$ \\
\hline Shellbed & & Crustaceans & (3) & Cross-beds & $<$ \\
\hline Conglomerate & 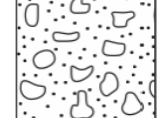 & Burrows & $g$ & Rip-up Clasts & $\square \otimes$ \\
\hline Tephra & vvvvvv & & & & \\
\hline
\end{tabular}


Appendix Two

Macrofossils 


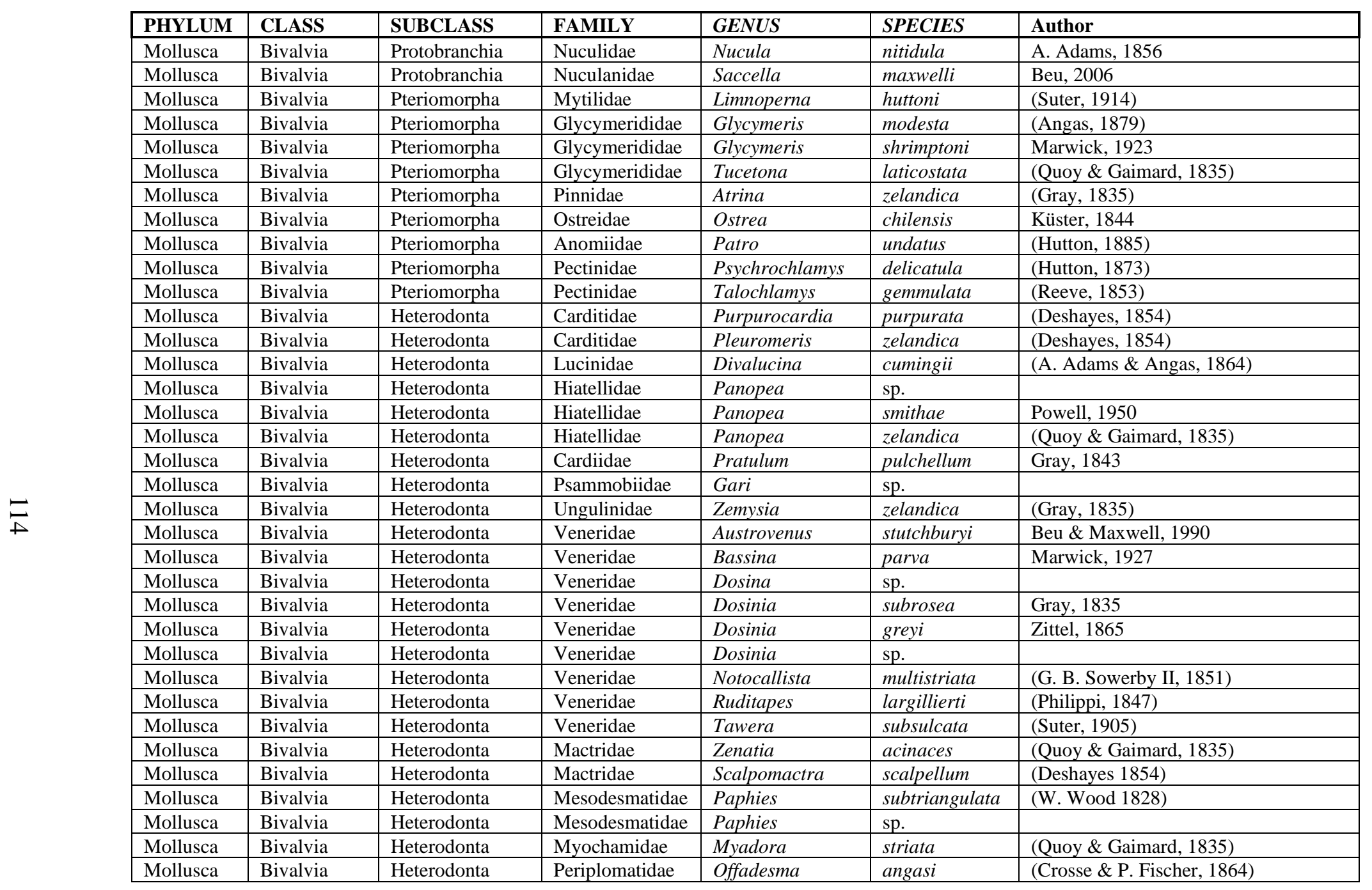




\begin{tabular}{|c|c|c|c|c|c|c|}
\hline PHYLUM & CLASS & SUBCLASS & FAMILY & GENUS & SPECIES & Author \\
\hline Mollusca & Gastropoda & Vetigastropoda & Calliostomatidae & Calliostoma & sp. & \\
\hline Mollusca & Gastropoda & Vetigastropoda & Trochidae & Antisolarium & egenum & (Gould, 1849) \\
\hline Mollusca & Gastropoda & Vetigastropoda & Trochidae & Roseaplagis & caelatus & (Hutton, 1884) \\
\hline Mollusca & Gastropoda & Vetigastropoda & Trochidae & Zethalia & zelandica & Hombron \& Jacquinot, 1854 \\
\hline Mollusca & Gastropoda & Heterobranchia & Pyramidelloidea & Agatha & georgiana & (Hutton, 1885) \\
\hline Mollusca & Gastropoda & Caenogastropoda & Calyptraeidae & Sigapatella & novaezelandiae & Lesson, 1831 \\
\hline Mollusca & Gastropoda & Caenogastropoda & Struthiolariidae & Pelicaria & vermis & (Martyn, 1784) \\
\hline Mollusca & Gastropoda & Caenogastropoda & Turritellidae & Maoricolpus & roseus & (Quoy \& Gaimard, 1834) \\
\hline Mollusca & Gastropoda & Caenogastropoda & Turritellidae & Zeacolpus & vittatus & (Hutton, 1873) \\
\hline Mollusca & Gastropoda & Caenogastropoda & Turritellidae & Stiracolpus & symmetricus & (Hutton, 1873) \\
\hline Mollusca & Gastropoda & Caenogastropoda & Buccinidae & Aeneator & marshalli & (R. Murdoch 1924) \\
\hline Mollusca & Gastropoda & Caenogastropoda & Buccinidae & Austrofusus & cottoni & King, 1933 \\
\hline Mollusca & Gastropoda & Caenogastropoda & Buccinidae & Penion & sp. & \\
\hline Mollusca & Gastropoda & Caenogastropoda & Horaiclavidae & Aoteadrillia & wanganuiensis & (Hutton, 1873) \\
\hline Mollusca & Gastropoda & Caenogastropoda & Muricidae & Xymene & sp. & \\
\hline Mollusca & Gastropoda & Caenogastropoda & Ancillariidae & Amalda & australis & (G. B. Sowerby I, 1830) \\
\hline Mollusca & Gastropoda & Caenogastropoda & Ancillariidae & Amalda & mucronata & (G. B. Sowerby I, 1830) \\
\hline Mollusca & Gastropoda & Caenogastropoda & Volutidae & Alcithoe & arabica & (Gmelin, 1791) \\
\hline Arthropoda & Malacostraca & Eumalacostraca & Majidae & Jacquinotia & edwardsii & (Jacquinot in Jacquinot \& Lucas, 1853) \\
\hline Arthropoda & Hexanauplia & Thecostraca & Balanidae & Notomegabalanus & decorus & (Darwin, 1984) \\
\hline
\end{tabular}




\section{Bivalvia}

\begin{tabular}{|c|c|c|c|c|c|c|c|c|c|c|c|c|c|c|c|c|c|c|c|c|c|c|c|c|c|c|c|}
\hline Unit name & $\begin{array}{l}\widetilde{O} \\
\stackrel{y}{I}\end{array}$ & 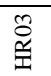 & $\begin{array}{l}\text { 苂 } \\
\text { 采 }\end{array}$ & $\begin{array}{l}\stackrel{8}{8} \\
\mathscr{y}\end{array}$ & 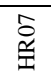 & $\frac{n}{\underline{y}}$ & $\begin{array}{l}0 \\
\mathbb{Z}\end{array}$ & $\stackrel{\bar{\Xi}}{\underline{I}}$ & $\begin{array}{l}\infty \\
\dddot{y}\end{array}$ & 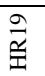 & 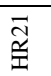 & 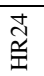 & 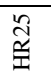 & 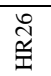 & 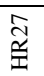 & 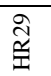 & 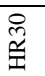 & $\begin{array}{l}\overline{\tilde{m}} \\
\stackrel{\underline{y}}{*}\end{array}$ & $\begin{array}{l}\widetilde{\widetilde{N}} \\
\text { 约 }\end{array}$ & 㐱 & 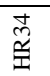 & $\begin{array}{l}\tilde{\tilde{y}} \\
\stackrel{\Xi}{\exists}\end{array}$ & $\begin{array}{l}\overrightarrow{\vec{a}} \\
\text { 荘 }\end{array}$ & $\begin{array}{l}\text { Õ } \\
\text { đ্] }\end{array}$ & 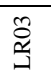 & $\begin{array}{l}\text { d } \\
\text { of }\end{array}$ & $\begin{array}{l}\stackrel{8}{a} \\
\text { a }\end{array}$ \\
\hline Nucula nitidula & & $\mathrm{x}$ & & & & & & & & & & & & & & & & & & & & & & & & & \\
\hline Saccella maxwelli & & & $\mathrm{x}$ & & & & & & & & & & & & & & & & & & & & & & & & \\
\hline Limnoperna huttoni & & & & & & $\mathrm{x}$ & & $\mathrm{x}$ & $\mathrm{x}$ & & & & & & & & & & & & & & & & & & \\
\hline Glycymeris modesta & & & & & & & & & & & & & & & & & & & $\mathrm{x}$ & & $\mathrm{x}$ & & & & & & \\
\hline Glycymeris shrimptoni & & & & & & & & & & & & & & & & & & & $\mathrm{x}$ & & & & & & & & \\
\hline \multicolumn{28}{|l|}{ Tucetona laticostata } \\
\hline Atrina zelandica & & & $\mathrm{x}$ & & & & & & & & & & & & & & & & & & & & & & & & \\
\hline Ostrea chilensis & $\mathrm{x}$ & & & & & & & & $\mathrm{x}$ & & & & & & & & & & & & & & & & & & $\mathrm{x}$ \\
\hline Patro undatus & & & & & & & & $\mathrm{x}$ & & & & & & & & & & & & & & & & & & & \\
\hline Psychrochlamys delicatula & $\mathrm{x}$ & $\mathrm{x}$ & & $\mathrm{x}$ & & & & & & & & & & & & & & & & & & & & & & & \\
\hline Talochlamys gemmulata & $\mathrm{x}$ & $\mathrm{x}$ & $\mathrm{x}$ & $\mathrm{x}$ & & & $\mathrm{x}$ & & $\mathrm{x}$ & & & $\mathrm{x}$ & & $\mathrm{x}$ & & $\mathrm{x}$ & & & & & & & & $\mathrm{x}$ & & & \\
\hline \multicolumn{28}{|l|}{ Purpurocardia purpurata } \\
\hline Pleuromeris zelandica & & & & & & & & & & & & & & & & $\mathrm{x}$ & & $\mathrm{x}$ & $\mathrm{x}$ & & & & & & & & \\
\hline Divalucina cumingii & & $\mathrm{x}$ & & & & & & & $\mathrm{x}$ & $\mathrm{x}$ & & & & & & & & & & & & & & & & & \\
\hline Panopea sp. & $\mathrm{x}$ & $\mathrm{x}$ & & & & & $\mathrm{x}$ & & $\mathrm{x}$ & $\mathrm{x}$ & $\mathrm{x}$ & & $\mathrm{x}$ & & & & & & & $\mathrm{x}$ & & & $\mathrm{x}$ & $\mathrm{x}$ & & & $\mathrm{x}$ \\
\hline \multicolumn{28}{|l|}{ Panopea smithae } \\
\hline \multicolumn{28}{|l|}{ Panopea zelandica } \\
\hline Pratulum pulchellum & & & $\mathrm{x}$ & & & & & & $\mathrm{x}$ & & & & & & & & & & & & & & & & & & \\
\hline Gari sp. & & & & $\mathrm{x}$ & & & & & & & & & $\mathrm{x}$ & & & & $\mathrm{x}$ & & $\mathrm{x}$ & & & & & & & & $\mathrm{x}$ \\
\hline Zemysia zelandica & & & & & & & & & & & & & & & & & & & & & $\mathrm{x}$ & & & & & & \\
\hline Austrovenus stutchburyi & & & & $\mathrm{x}$ & & $\mathrm{x}$ & & $\mathrm{x}$ & & & & & & & $\mathrm{x}$ & $\mathrm{x}$ & & $\mathrm{x}$ & $\mathrm{x}$ & & & & & & & & \\
\hline Bassina parva & & & & & & & & & & & & $\mathrm{x}$ & & & & & & & 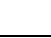 & & & & & $\mathrm{x}$ & & $\mathrm{x}$ & $\mathrm{x}$ \\
\hline Dosina sp. & & & & & & & & & & & & $\mathrm{x}$ & $\mathrm{x}$ & & & & & . & $\mathrm{x}$ & $\mathrm{x}$ & $\mathrm{x}$ & & & & $\mathrm{x}$ & & \\
\hline Dosinia subrosea & $\mathrm{x}$ & & & $\mathrm{x}$ & & & & & & & & & & & & & & $\mathrm{x}$ & & & & & & & & & $\mathrm{x}$ \\
\hline Dosinia greyi & & & & & & & $\mathrm{x}$ & & $\mathrm{x}$ & & $\mathrm{x}$ & & & & & & & & & & & $\mathrm{x}$ & & $\mathrm{x}$ & & $\mathrm{x}$ & $\mathrm{x}$ \\
\hline \multicolumn{28}{|l|}{ Dosinia sp. } \\
\hline Notocallista multistriata & & & & & & & & & $\mathrm{x}$ & & & & & & & & & & & & & & & & & & \\
\hline Ruditapes largillierti & $\mathrm{x}$ & & & $\mathrm{x}$ & & & & & & & & & & & & & & & & & & & & & & & \\
\hline Tawera subsulcata & & & & $\mathrm{x}$ & & & $\mathrm{x}$ & & $\mathrm{x}$ & & & & & $\mathrm{x}$ & $\mathrm{x}$ & & & & $\mathrm{x}$ & & $\mathrm{x}$ & & & $\mathrm{x}$ & $\mathrm{x}$ & $\mathrm{x}$ & $\mathrm{x}$ \\
\hline Zenatia acinaces & & $\mathrm{x}$ & & & & & & & & & & $\mathrm{x}$ & $\mathrm{x}$ & & & & & & & & & & $\mathrm{x}$ & $\mathrm{x}$ & & & \\
\hline Scalpomactra scalpellum & & & $\mathrm{x}$ & & & & & $\mathrm{x}$ & & & & & & & & & & & & & & & & & & & \\
\hline Paphies subtriangulata & & & & & & & & & & & & $\mathrm{x}$ & & & & & & & & & & & & & & & \\
\hline Paphies sp. & & & & & & & & & & & & & & & & & & & $\mathrm{x}$ & & & & & $\mathrm{x}$ & & & \\
\hline Myadora striata & & & & & & & & & & & & & & $\mathrm{x}$ & & & & & $\mathrm{x}$ & & & & & $\mathrm{x}$ & $\mathrm{x}$ & & $\mathrm{x}$ \\
\hline Offadesma angasi & & & & & & & & & $\mathrm{x}$ & & & & & & & & & & & & & & & & & & \\
\hline
\end{tabular}




\section{Gastropoda}

\begin{tabular}{|c|c|c|c|c|c|c|c|c|c|c|c|c|c|c|c|c|c|c|c|c|c|c|c|c|c|c|c|}
\hline Unit name & 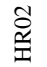 & 产 & $\begin{array}{l}\text { 总 } \\
\text { 亲 }\end{array}$ & 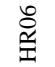 & 产 & $\stackrel{n}{\tilde{z}}$ & $\stackrel{0}{\underline{x}}$ & 馬 & $\begin{array}{l}\infty \\
\mathbb{x} \\
\mathbb{I}\end{array}$ & $\stackrel{\overrightarrow{\vec{Z}}}{\underline{\Psi}}$ & $\overrightarrow{\widetilde{\mathbb{\Xi}}}$ & 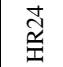 & Æֶ̃ & 苋 & ָ̃ & ฏે & 离 & $\overrightarrow{\underline{\underline{x}}}$ & 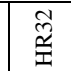 & $\begin{array}{l}\mathscr{\dddot { \varkappa }} \\
\text { }\end{array}$ & $\begin{array}{l}\text { 志 } \\
\cong\end{array}$ & \begin{tabular}{|l|}
$\mathscr{\tilde { n }}$ \\
$\tilde{\tilde{x}}$
\end{tabular} & $\overline{\stackrel{\bar{\Xi}}{\exists}}$ & 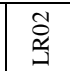 & 喽 & 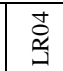 & 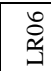 \\
\hline Calliostoma sp. & & & & & & & & & & $\mathrm{x}$ & & & & & & & & & & & & & & & & & \\
\hline Antisolarium egenum & & & & & & & & $\mathrm{x}$ & & & & $\mathrm{x}$ & & & & & & & & & & & $\mathrm{x}$ & & & & \\
\hline Roseaplagis caelatus & & & & & & & & & & & & & & & & & & & $\mathrm{x}$ & & & & & & & & \\
\hline Zethalia zelandica & & & & & & & & & & & & & & & $\mathrm{x}$ & & & & $\mathrm{x}$ & & $\mathrm{x}$ & $\mathrm{x}$ & & & & & \\
\hline Agatha georgiana & & & & & & & & & & & & & & & & & & & $\mathrm{x}$ & & & & & & & & \\
\hline Sigapatella novaezelandiau & & & $\mathrm{x}$ & & & & & & & & & & & & & & & & & & & & & & & & \\
\hline Pelicaria vermis & $\mathrm{x}$ & $\mathrm{x}$ & & & & & $\mathrm{x}$ & & $\mathrm{x}$ & & $\mathrm{x}$ & $\mathrm{x}$ & $\mathrm{x}$ & $\mathrm{x}$ & & & & & & & & & $\mathrm{x}$ & $\mathrm{x}$ & & $\mathrm{x}$ & \\
\hline Struthiolaria $s p$. & & & & & & & & & & & & & & & & & & & & & & & $\mathrm{x}$ & $\mathrm{x}$ & & & $\mathrm{x}$ \\
\hline Maoricolpus roseus & & $\mathrm{x}$ & & & $\mathrm{x}$ & & & & & & & & & & & & & & & & & & & & & & \\
\hline Zeacolpus vittatus & & & $\mathrm{x}$ & & & & & & & & & & & & & & & & & & & & & & & & \\
\hline Stiracolpus symmetricus & $\mathrm{x}$ & $\mathrm{x}$ & & $\mathrm{x}$ & & & & & & & & & & & & & & & & & & & & & & & $\mathrm{x}$ \\
\hline Aeneator marshalli & & & & $\mathrm{x}$ & & & & & & & & & & & & & & & & $\mathrm{x}$ & & & & & & & \\
\hline A. imperator & & & & & & & & & & & & $\mathrm{x}$ & & & & & & & & & & & & & & & \\
\hline Aeneator sp. & & & & & & & & & & & & & & & & & & & & & $\mathrm{x}$ & & & & & & \\
\hline Austrofusus cottoni & & & & & & & $\mathrm{x}$ & & $\mathrm{x}$ & & & & & & & & & & & & & & & & & & \\
\hline Austrofusus sp. & & & & & & & & & & & & $\mathrm{x}$ & $\mathrm{x}$ & & & & & & & & & & $\mathrm{x}$ & $\mathrm{x}$ & & & $\mathrm{x}$ \\
\hline Aoteadrillia wanganuiensis & & & & & & & & & $\mathrm{x}$ & & & & & & & & & & & & & & & & & & \\
\hline Xymene sp. & & & & & & & & & & & & $\mathrm{x}$ & & & & & & & & & & & & & & & \\
\hline Amalda australis & & & & & & & $\mathrm{x}$ & & $\mathrm{x}$ & & & & $\mathrm{x}$ & & & & & & $\mathrm{x}$ & & & & & & & & \\
\hline Amalda mucronata & & & & $\mathrm{x}$ & $\mathrm{x}$ & $\mathrm{x}$ & & & & & & $\mathrm{x}$ & & & & & & & $\mathrm{x}$ & $\mathrm{x}$ & $\mathrm{x}$ & & & $\mathrm{x}$ & & & $\mathrm{x}$ \\
\hline Alcithoe arabica & $\mathrm{x}$ & $\mathrm{x}$ & & & & & & & $\mathrm{x}$ & $\mathrm{x}$ & & & & & & & & & & & & & & $\mathrm{x}$ & & $\mathrm{x}$ & $\mathrm{x}$ \\
\hline Alcithoe sp. & & & & & & & & & & & & & & $\mathrm{x}$ & & & & & & & & & & & & & \\
\hline
\end{tabular}

\section{Arthropoda}

\begin{tabular}{|c|c|c|c|c|c|c|c|c|c|c|c|c|c|c|c|c|c|c|c|c|c|c|c|c|c|c|c|}
\hline Unit name & 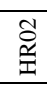 & 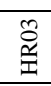 & $\begin{array}{l}+ \\
\text { 童 } \\
\end{array}$ & $\begin{array}{l}\text { \& } \\
\text { İ }\end{array}$ & 氧 & $\frac{n}{2}$ & $\begin{array}{l}0 \\
\stackrel{0}{\underline{x}}\end{array}$ & 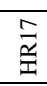 & $\stackrel{\infty}{\underline{\underline{I}}}$ & $\stackrel{\partial}{\tilde{x}}$ & $\overline{\widetilde{\Xi}}$ & 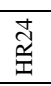 & 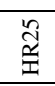 & Æֶ̃ & $\overline{\tilde{z}}$ & జิ & $\begin{array}{l}\mathscr{\cong} \\
\text { I }\end{array}$ & $\overrightarrow{\widetilde{\cong}}$ & 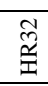 & 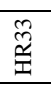 & 志 & 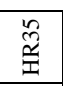 & $\overline{\stackrel{\mathscr{\vartheta}}{U}}$ & $\begin{array}{l}\tilde{\mathscr{Z}} \\
\stackrel{\Xi}{3}\end{array}$ & $\begin{array}{l}\stackrel{8}{8} \\
\stackrel{3}{3}\end{array}$ & 莺 & \begin{tabular}{l} 
\\
$ٌ$ \\
\hdashline
\end{tabular} \\
\hline Jacquinotia edwardsii & & & & $\mathrm{x}$ & & & & & & & & & & & & & & & & & & & & & & & \\
\hline Notomegabalanus decorus & & $\mathrm{x}$ & $\mathrm{x}$ & & & & & & $\mathrm{x}$ & & & $\mathrm{x}$ & & & & $\mathrm{x}$ & & & & & & & & & & & \\
\hline Kina (unknown) & & & & & & & & & $\mathrm{x}$ & & & & & & & & & & & & & & & & & & \\
\hline
\end{tabular}




\section{Plate One}

1.1 - Nucula nitidula $($ scale bar $=10 \mathrm{~mm})$

1.2 - Saccella maxwelli $($ Scale bar $=10 \mathrm{~mm})$

1.3 - Limnoperna huttoni $($ Scale bar $=50 \mathrm{~mm})$

1.4 - Glycymeris modesta $($ Scale bar $=50 \mathrm{~mm})$

1.5 - Glycymeris shrimptoni $($ Scale bar $=50 \mathrm{~mm})$

1.6 - Atrina zelandica $($ Scale bar $=10 \mathrm{~mm})$

1.7 - Ostrea chilensis $($ Scale bar $=50 \mathrm{~mm})$

1.8 - Patro undatus $($ Scale bar $=50 \mathrm{~mm})$

1.9 - Psychrochlamys delicatula $($ Scale bar $=50 \mathrm{~mm})$

1.10 - Talochlamys gemmulata $($ Scale bar $=30 \mathrm{~mm})$ 

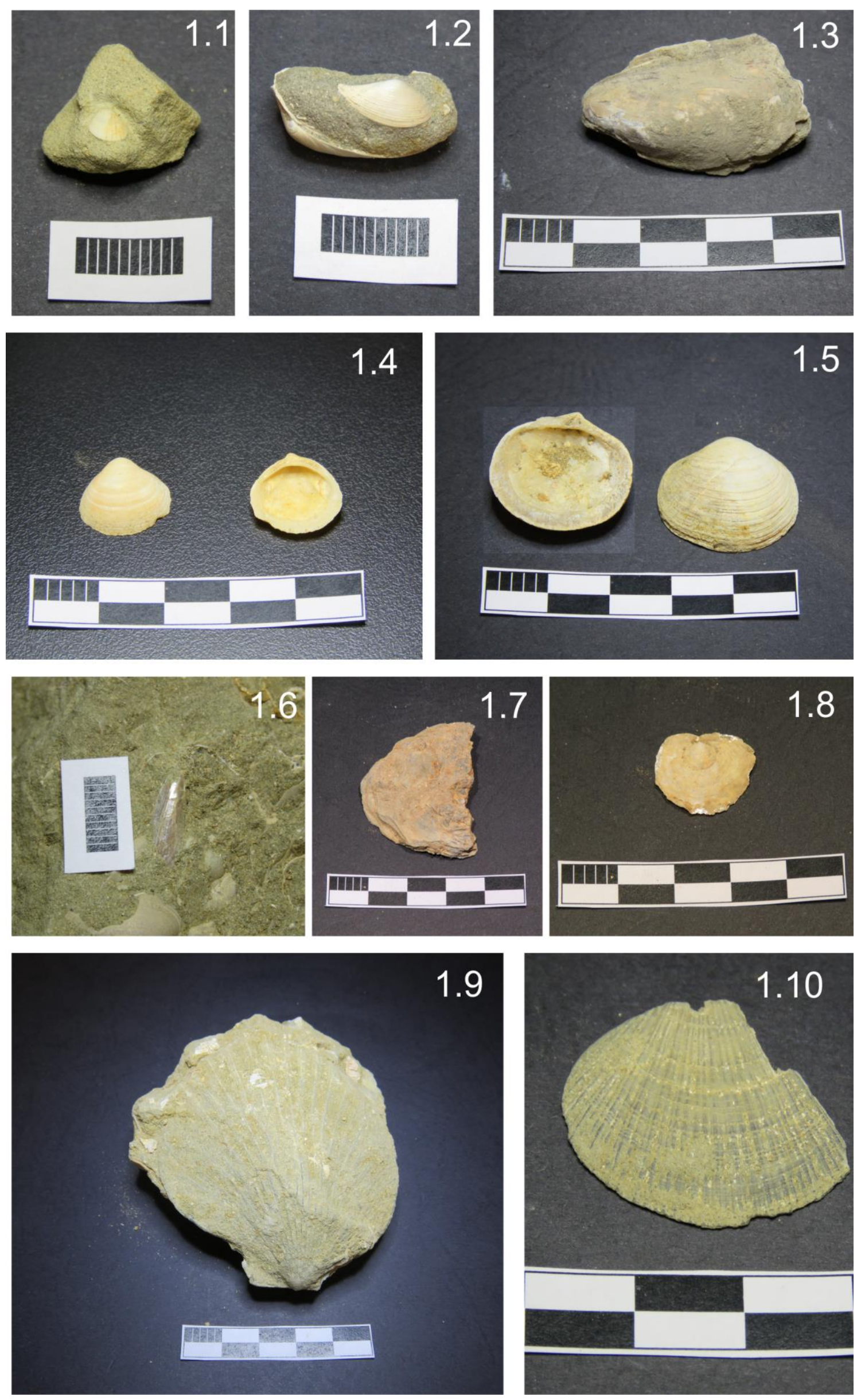


\section{Plate Two}

2.1 - Pleuromeris zelandica $($ scale bar $=10 \mathrm{~mm})$

2.2 - Divalucina cumingii $($ Scale bar $=20 \mathrm{~mm})$

2.3 - Panopea $\mathrm{sp} .($ Scale bar $=50 \mathrm{~mm})$

2.4 - Pratulum pulchellum $($ Scale bar $=50 \mathrm{~mm})$

2.5 - Gari lineolata $($ Scale bar $=50 \mathrm{~mm})$

2.6 - Zemysia zelandica $($ Scale bar $=50 \mathrm{~mm})$

2.7 - Austrovenus stutchburyi (Scale bar $=50 \mathrm{~mm})$

2.8 - Bassina parva $($ Scale bar $=50 \mathrm{~mm})$

2.9 - Dosinia sp. $($ Scale bar $=50 \mathrm{~mm})$

2.10 - Notocallista multistriata $($ Scale bar $=10 \mathrm{~mm})$

2.11 - Ruditapes largillierti $($ Scale bar $=50 \mathrm{~mm})$

2.12 - Tawera subsulcata $($ Scale bar $=50 \mathrm{~mm})$

2.13 - Zenatia acinaces $($ Scale bar $=50 \mathrm{~mm})$

2.14 - Scalpomactra scalpellum $($ Scale bar $=50 \mathrm{~mm})$

2.15 - Myadora striata $($ Scale bar $=50 \mathrm{~mm})$

2.16 - Offadesma angasi $($ Scale bar $=50 \mathrm{~mm})$ 

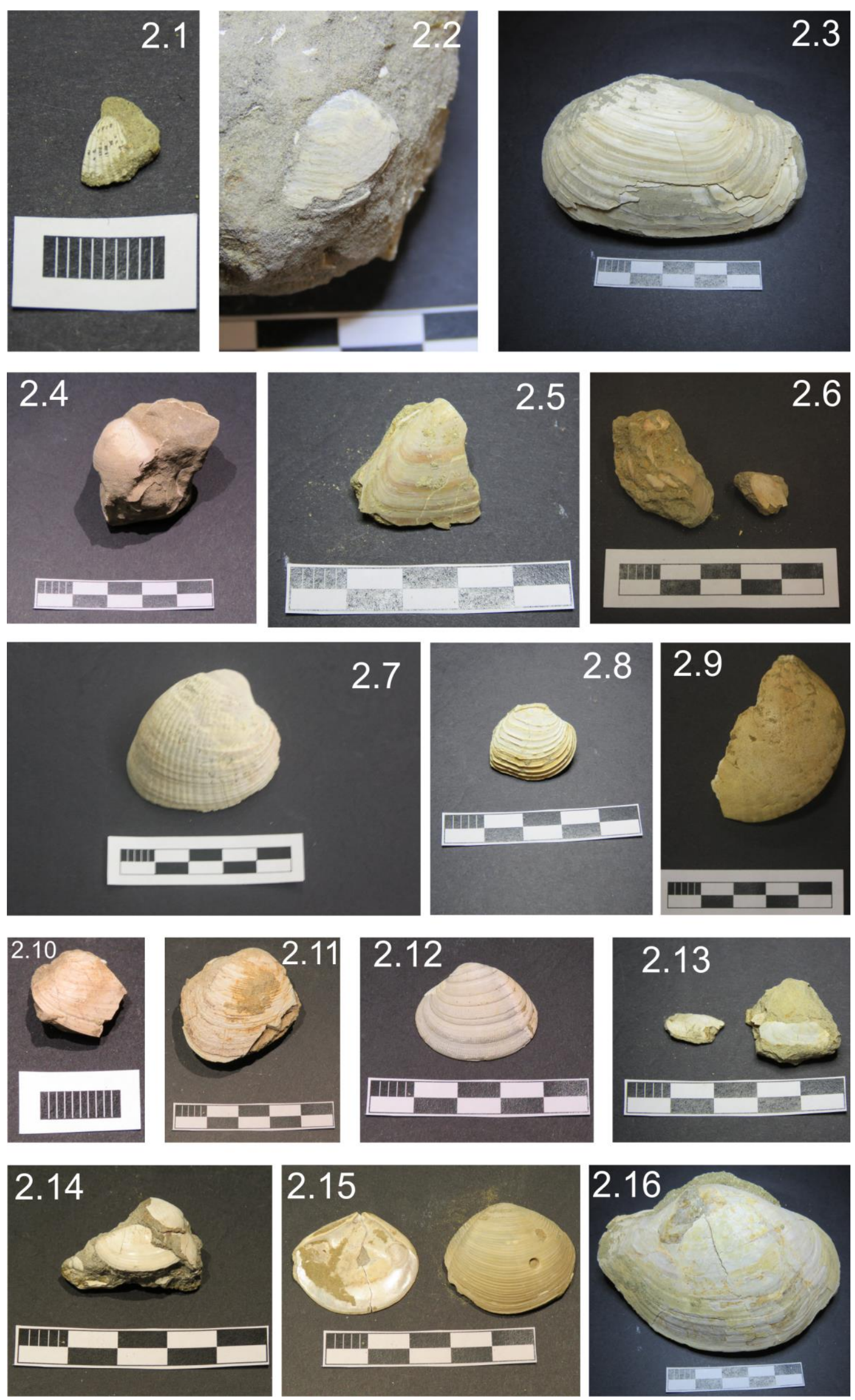


\section{Plate Three}

3.1 - Calliostoma sp. (Lens cap $=50 \mathrm{~mm})$

3.2 - Antisolarium egenum $($ Scale bar $=10 \mathrm{~mm})$

3.3 - Roseaplagis caelatus $($ Scale bar $=10 \mathrm{~mm})$

3.4 - Zethalia zelandica $($ Scale bar $=10 \mathrm{~mm})$

3.5 - Agatha georgiana $($ Scale bar $=50 \mathrm{~mm})$

3.6 - Sigapatella novaezelandiae $($ Scale bar $=10 \mathrm{~mm})$

3.7 - Pelicaria vermis $($ Scale bar $=50 \mathrm{~mm})$

3.8 - Zeacolpus vittatus $($ Scale bar $=50 \mathrm{~mm})$

3.9 - Stiracolpus symmetricus $($ Scale bar $=10 \mathrm{~mm})$

3.10 - Aeneator marshalli $($ Scale bar $=50 \mathrm{~mm})$

3.11 - Austrofusus cottoni $($ Scale bar $=50 \mathrm{~mm})$

3.12 - Aoteadrillia wanganuiensis $($ Scale bar $=10 \mathrm{~mm})$

3.13 - Xymene sp. $($ Scale bar $=10 \mathrm{~mm})$

3.14 - Amalda australis $($ Scale bar $=50 \mathrm{~mm})$

3.15 - Amalda mucronata (Scale bar $=50 \mathrm{~mm}$ )

3.16 - Alcithoe arabica $($ Scale bar $=50 \mathrm{~mm})$ 

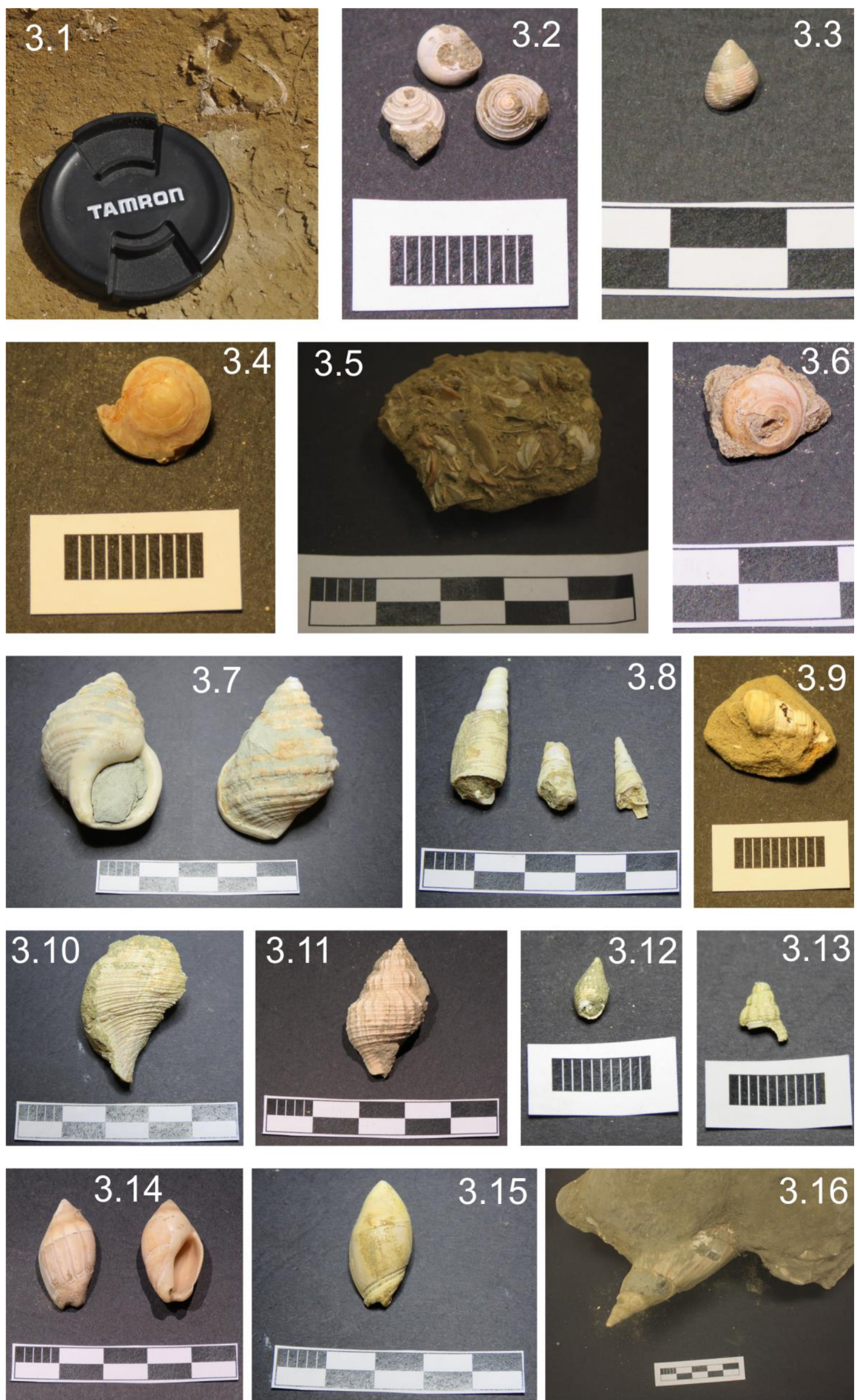


\section{Plate Four}

4.1 - Jacquinotia edwardsii $($ Scale bar $=50 \mathrm{~mm})$

4.2 - Notomegabalanus decorus $($ Scale bar $=50 \mathrm{~mm})$

4.3 - Echinoida indet. $($ Scale bar $=50 \mathrm{~mm})$ 

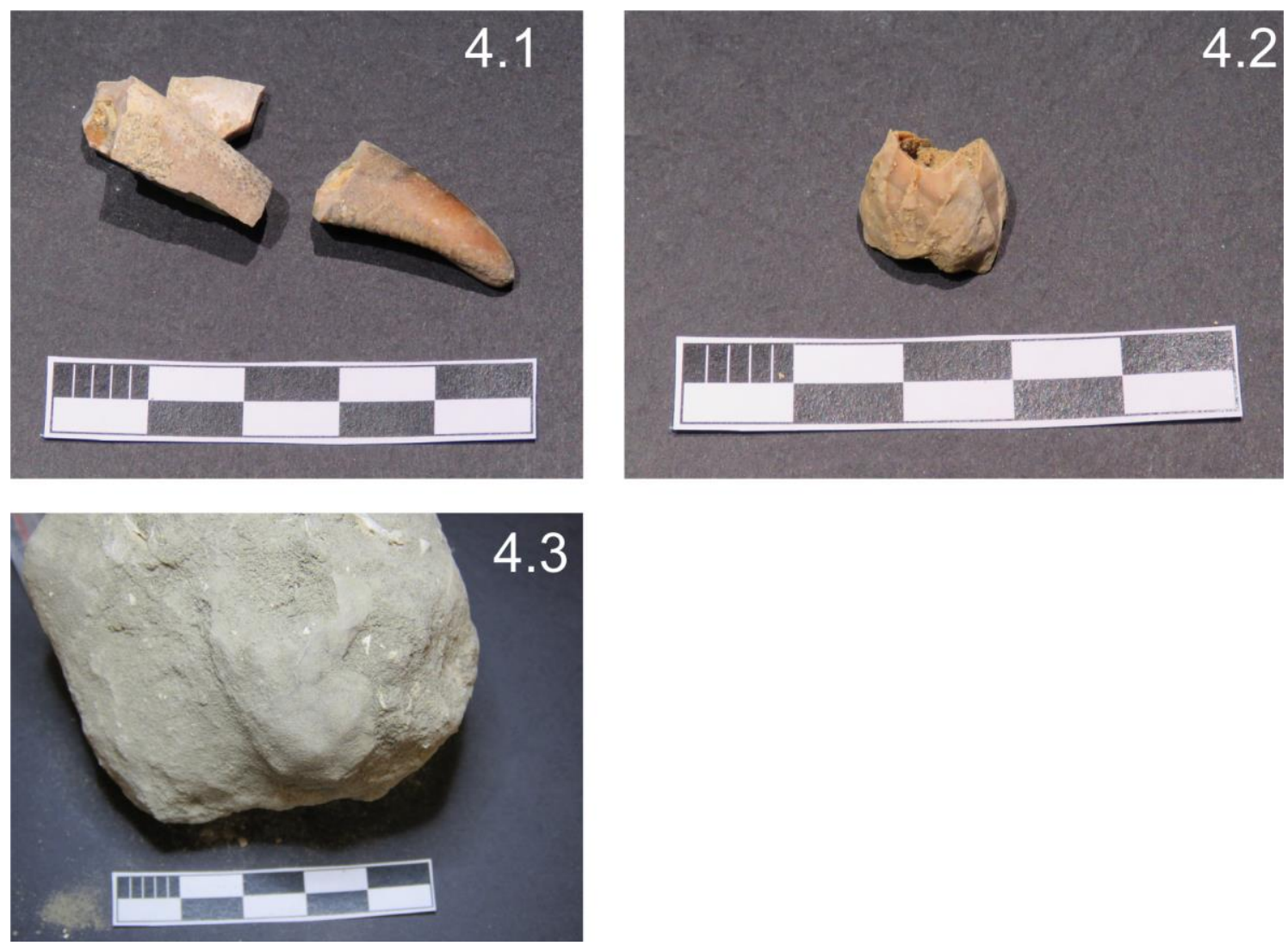
Locality: Longbush Road

Location reference: BQ34 1420.0-3208.0 to BQ34 1450.0-3208.4

Enclosure B

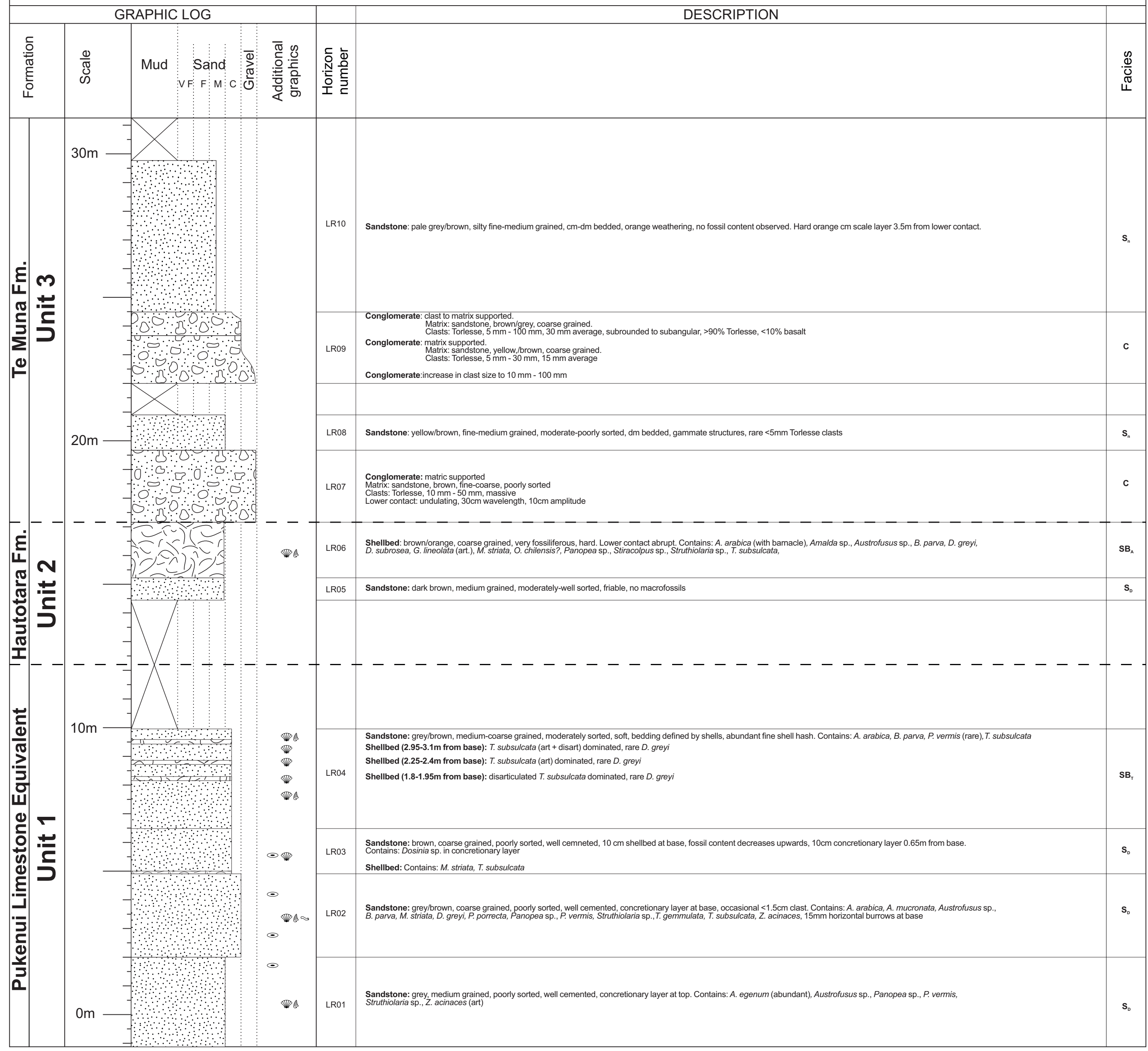

